\title{
THE IMPACT OF BUILDING ENVELOPE RETROFIT MEASURES ON POSTWAR MURBS IN TORONTO
}

\author{
by \\ Sara Damyar \\ B. Arch Sc, Ryerson University, 2006 \\ A Major Research Project \\ presented to Ryerson University \\ in fulfillment of the \\ requirements for the degree of \\ Masters of Building Science \\ in the Program of \\ Building Science
}

Toronto, Ontario, Canada, 2014

(C) Sara Damyar, 2014 


\section{Author's Declaration}

I hereby declare that I am the sole author of this MRP. This is a true copy of the MRP, including any required final revisions.

I authorize Ryerson University to lend this MRP to other institutions or individuals for the purpose of scholarly research

I further authorize Ryerson University to reproduce this MRP by photocopying or by other means, in total or in part, at the request of other institutions or individuals for the purpose of scholarly research.

I understand that my MRP may be made electronically available to the public. 
Impact of Building Envelope Retrofit Measures on Postwar MURBs in Toronto

Sara Damyar, MBSc, 2014

Master of Building Science

Ryerson University,

Toronto, Ontario, Canada

\section{Abstract}

Building envelope retrofits is one of the options available to reduce energy consumption of postwar MURBs in Toronto. This study evaluates the impact of building envelope retrofits that meet current standards on energy consumption of a Toronto postwar MURB; utilizing eQUEST energy simulation software. Further upgrades also take place to evaluate how the impact of building envelope retrofits on energy use can be increased and optimized for all assemblies of building envelope and airtightness. Moreover, the retrofit strategies are ranked based on cost and energy-saving effectiveness. The results of the analysis reveal that building envelope retrofit based on OBC-2012 standards can reduce the energy consumption by up to $44 \%$. Furthermore, the optimal RSI values of all building envelope components were found to be equal or less than code requirements which outcomes significant energy savings. Lastly, the ranking of the strategies helps to identify the best option according to the priorities of a project. 


\section{Acknowledgments}

There are a number of people without whom this MRP would not have been possible, and to whom I am greatly indebted. Firstly, I would like to express my sincere gratitude to my MRP supervisor, Vera Straka, whose encouragement, guidance and support from the initial to final stages have enabled me to develop my project. I also wish to thank Russell Richman for his professional expertise and valuable input toward. This MRP would not have been possible without the support of my family and friends: Saeed Damyar, Maysam Damyar, Talayeh Rad and Ali Julazadeh, thank you for showing your support during the good times and the bad. Last and most importantly, I would like to thank my parents Naesser Damyar and Mansoureh Asadi for supporting me in my determination to find and realize my potential.

To them I dedicate this MRP. 


\section{Table of Contents}

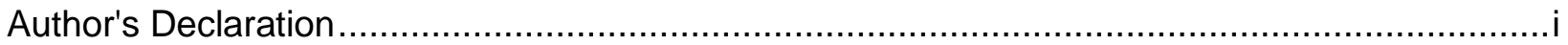

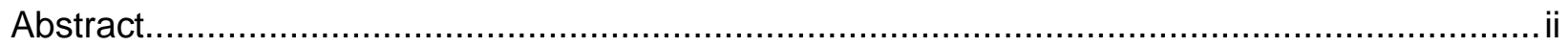

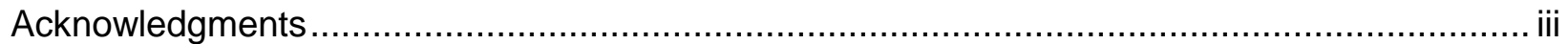

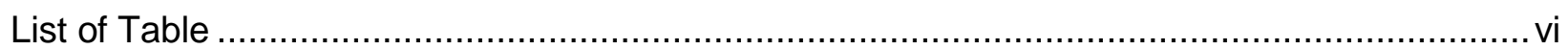

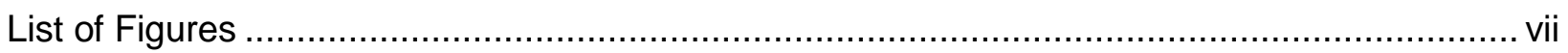

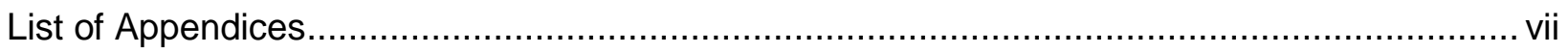

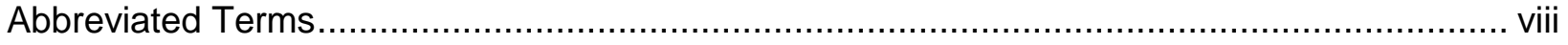

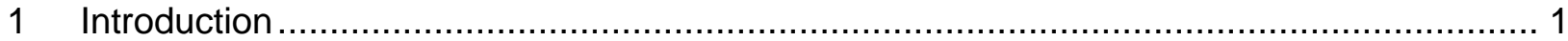

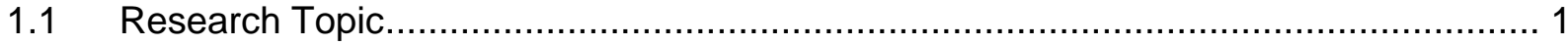

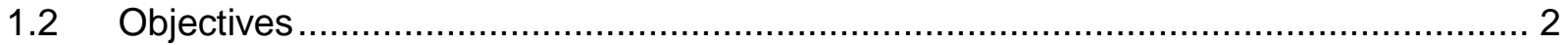

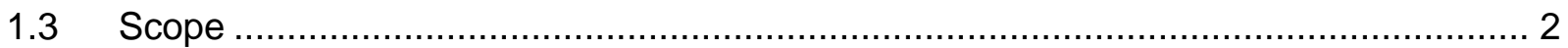

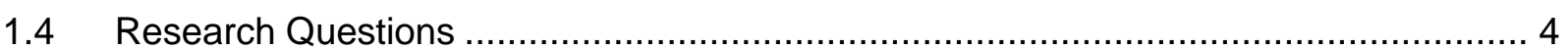

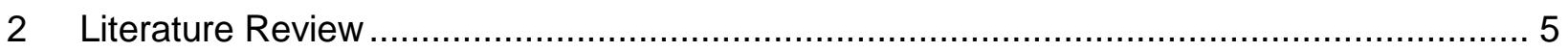

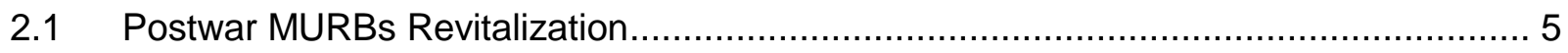

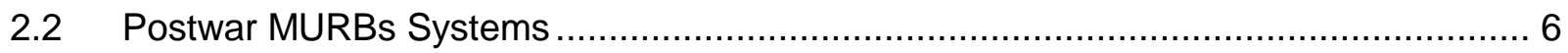

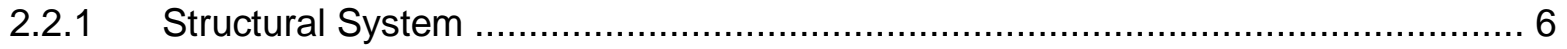

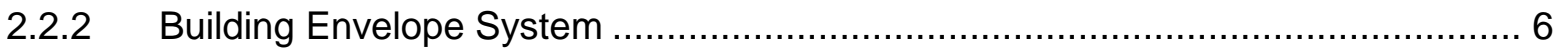

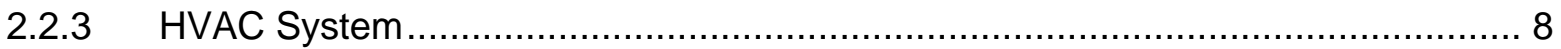

2.3 Postwar MURBs' Existing Building Envelope Condition .......................................... 8

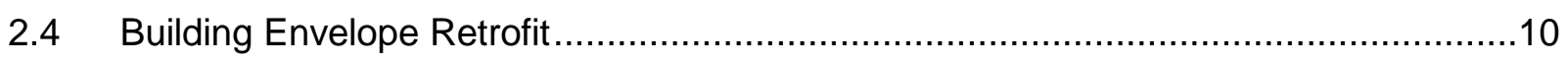

2.4.1 Opaque Elements of Building Envelope ......................................................11

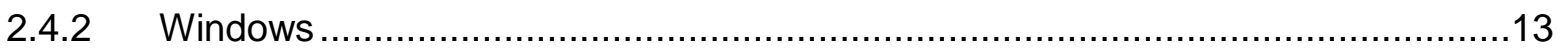

2.5 Building Envelope Retrofits and HVAC System.................................................13

2.6 Building Envelope Retrofits and Energy Efficiency ..............................................15

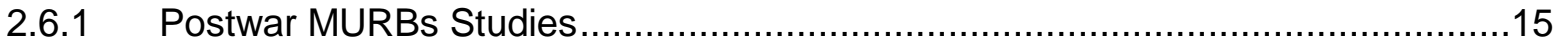

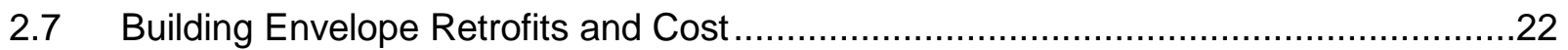

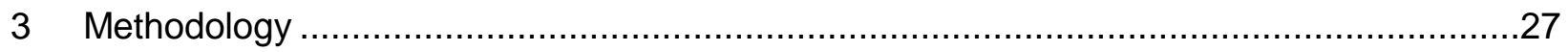

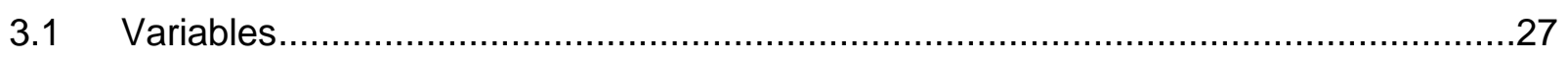

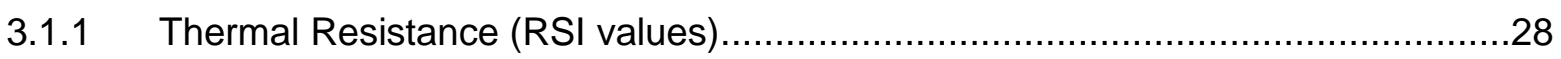

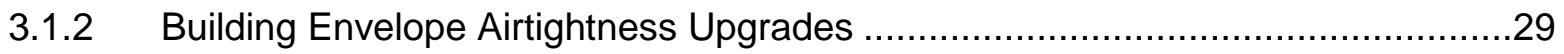

3.1.3 Combined Comprehensive Building Envelope Retrofit and Airtightness Upgrades 30 


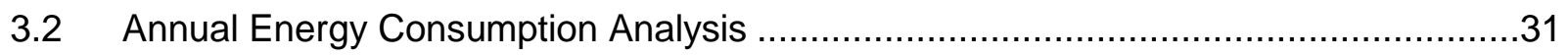

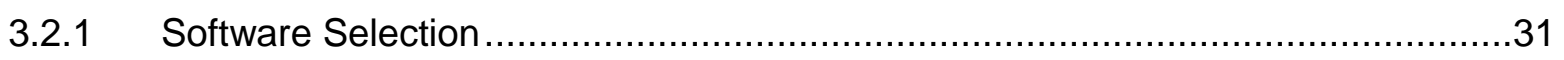

3.2.2 Data Collection and Base Case Energy Model Generation ..............................32

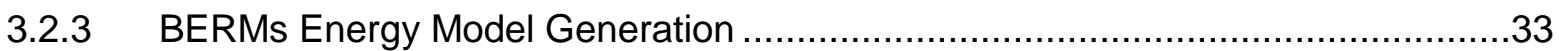

3.3 Ranking the Building Envelope Retrofit Options Based On Energy-Saving Measures

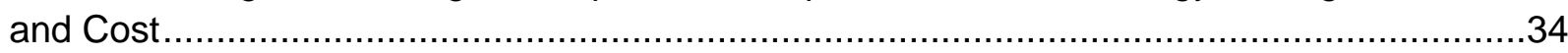

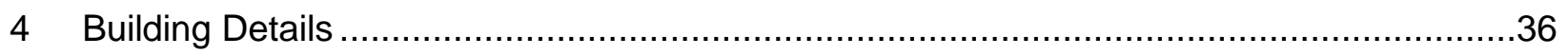

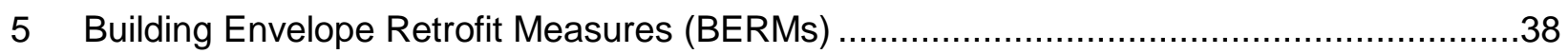

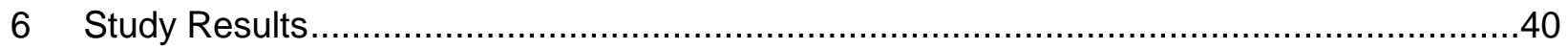

6.1 Building Envelope Upgrades Based On OBC 2012 (SB-10)................................40

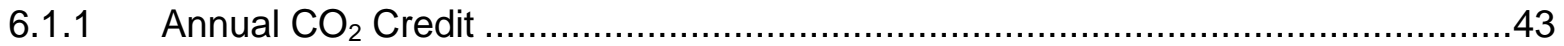

6.2 Incremental Upgrade of Building Envelope Components ......................................4

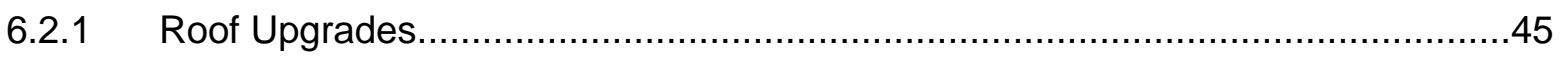

6.2.2 Exterior Wall and Slab/Balcony Edges Upgrades..........................................47

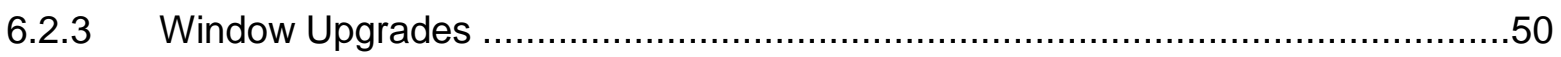

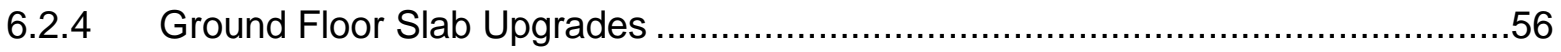

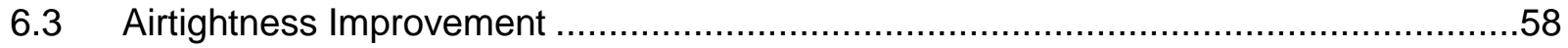

6.4 Combined Comprehensive Building Envelope Retrofit and Airtightness Upgrades .....60

7 Comparison of Building Envelope Retrofit Strategies .................................................63

8 Ranking Building Envelope Retrofit Strategies Based on Energy Efficiency, Initial Capital

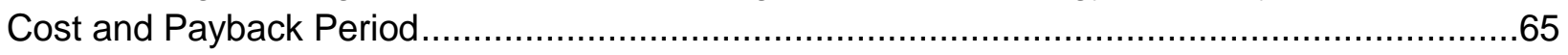

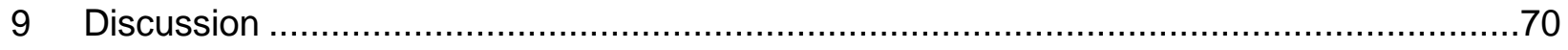

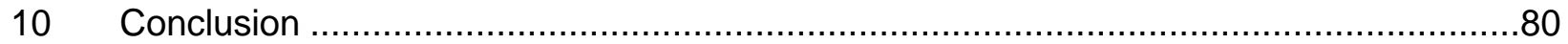

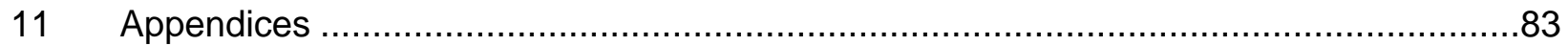

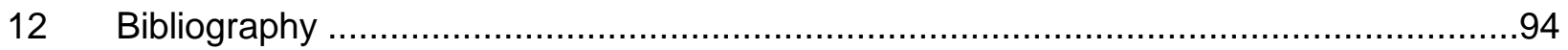




\section{List of Table}

Table 2-1 Annual energy use intensity for typical tower buildings located in Toronto, Ontario

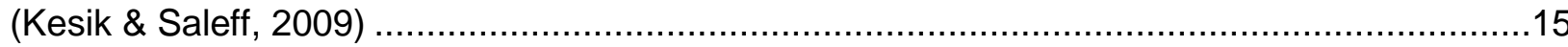

Table 2-2 Life cycle cost assessment of building envelope RCMs (Kesik \& Saleff, 2008) ........18

Table 2-3 Potential building envelope resource conservation measure (RCM) summary (ARUP

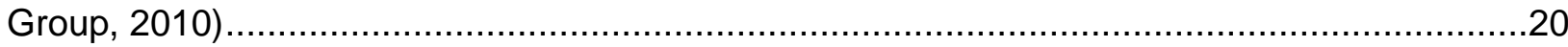

Table 2-4 Influence of building envelope RCMs insulation on energy intensity (Touchie,

Pressnail, \& Binkley, 2012) ............................................................................... 21

Table 2-5 Results of energy saving and payback time of Kesik and Saleff's Study..................24

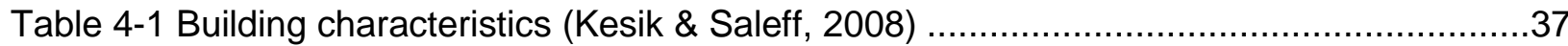

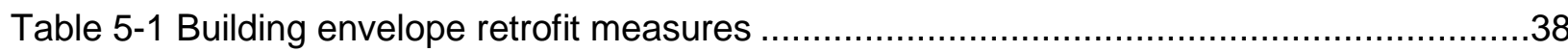

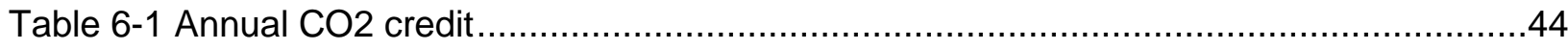

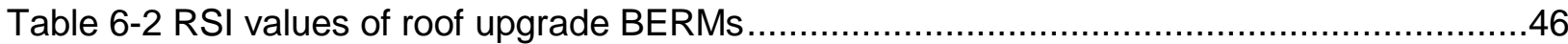

Table 6-3 RSI Values of over-cladding exterior wall and balcony slab upgrade BERMs ...........48

Table 6-4 RSI values of window upgrade BERMs with aluminum frame window without thermal

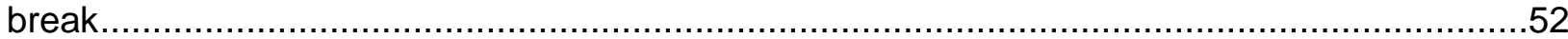

Table 6-5 RSI values of window upgrade BERMs with aluminum frame window with thermal

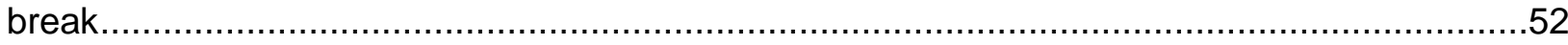

Table 6-6 RSI Values of window upgrade BERMs with insulated fiberglass frame with insulated

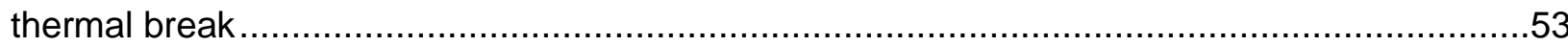

Table 6-7 RSI values of ground floor slab upgrade BERMs...........................................57

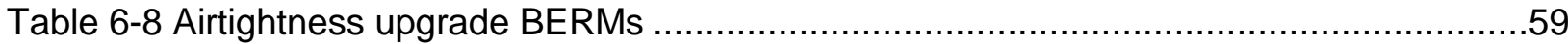

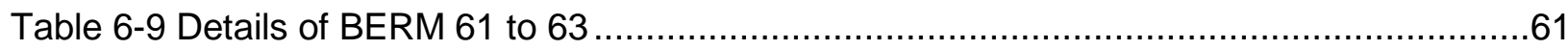

Table 8-1 Building envelope strategy ranking ...........................................................67

Table 8-2 Building envelope strategy ranking with energy efficiency having priority over other

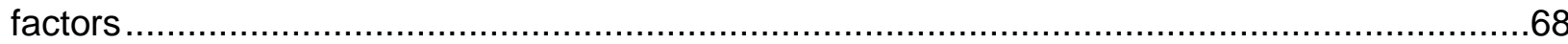

Table 9-1 The retrofit in each RCM in Kesik and Saleff's Study .......................................71

Table 9-2 Touchie's building envelope RCM results (Touchie, Pressnail, \& Binkley, 2012) .......72

Table 9-3 Summary of all study results ................................................................ 75

Table 12-1 Climate Zone Numbers for Ontario (SB 10/OBC 2012/ASHRAE 90.1) .................87

Table 12-2 Building Envelope Requirements for Toronto (SB 10/OBC 2012/ASHRAE 90.1)....88

Table 12-3 eQuest modeling results based on OBC $2012 \mathrm{RSI}$ measures .............................89

Table 12-4 eQUEST Modeling results for roof upgrade strategy ........................................89

Table 12-5 eQUEST Modelin results for over-cladding wall and balcony slab strategy.............90

Table 12-6 eQUEST Modeling results for window replacement (Aluminum frame without thermal

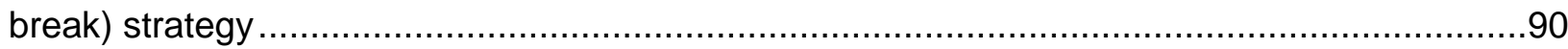

Table 12-7 eQUEST Modeling results for window replacement (Aluminum frame with insulated

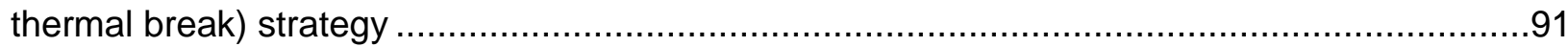

Table 12-8 eQUEST Modeling results for window replacement (Insulated fiberglass frame with

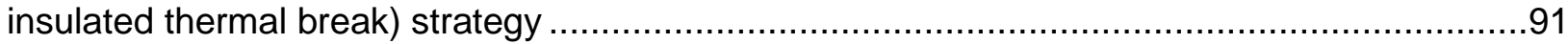

Table 12-9 eQUEST Modeling results for ground floor slab insulation strategy ......................92

Table 12-10 eQUEST Modeling results for airtightness strategy ......................................92

Table 12-11 eQUEST Modeling results for comprehensive building envelope retrofit and airtightness strategy 


\section{List of Figures}

Figure 2-1 Breakdown of energy use in the archetype tower building before and after retrofit (Kesik \& Saleff, 2009) 16

Figure 4-1 A typical floor plan of the archetype tower (Kesik \& Saleff, 2009) ……....................36

Figure 4-2 Axonometric view of the archetype tower (Kesik \& Saleff, 2009) .............................36

Figure 6-1 Annual energy consumption intensity analysis of upgrades of building envelope

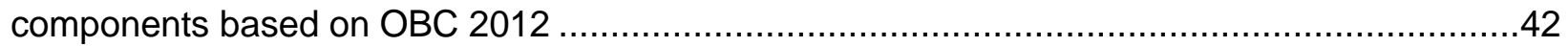

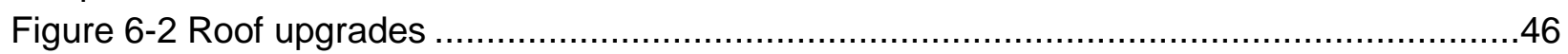

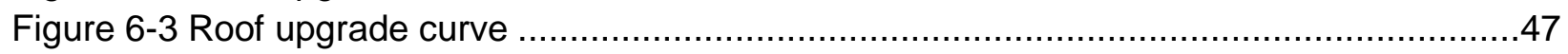

Figure 6-4 Exterior wall and balcony/slab edges upgrades ............................................48

Figure 6-5 Exterior wall and balcony/slab edges upgrades curve .......................................50

Figure 6-6 Aluminum frame without thermal break window upgrades....................................52

Figure 6-7 Aluminum frame with insulated thermal break window upgrades ...........................53

Figure 6-8 Insulated fiberglass frame with insulated thermal break window upgrades...............54

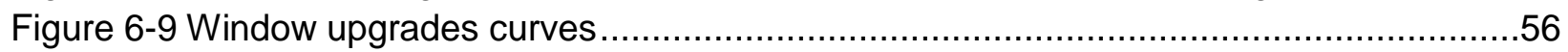

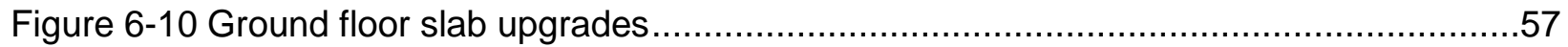

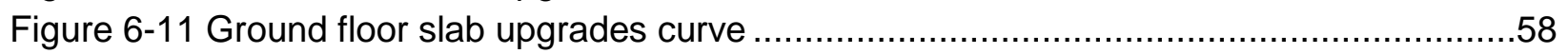

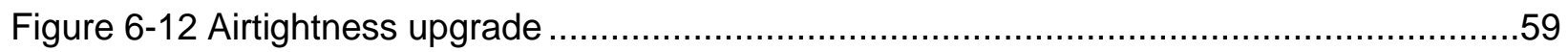

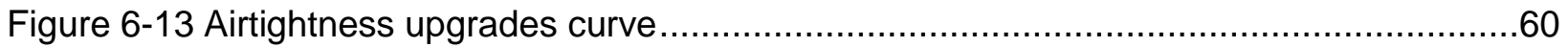

Figure 6-14 Impact of comprehensive building envelope retrofit and airtightness upgrade on

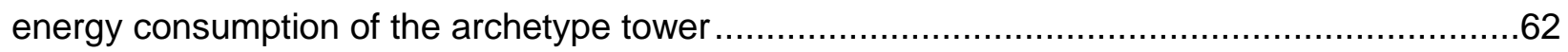

Figure 7-1 Components upgrades' improvement comparison (horizontal axis represents the upgrade in RSI values and airtightness which has been shown in the figure above. The OBC

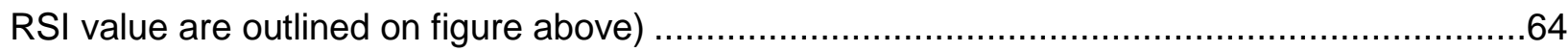

Figure 9-1 Comparison between the energy saving results of NRCan screening (Kesik and Saleff's study) and eQUEST (OBC 2012 (SB-10) RSI values of this MRP) .............................71

Figure 9-2 Comparison between the results of the studies ..............................................74

Figure 9-3 Comparison of airtightness upgrades between Touchie's Study and this MRP ........75

Figure 12-1 Ground Floor Plan (Kesik \& Saleff, 2009).................................................... 83

Figure 12-2 Typical Floor Plan (from 2nd to 20th Floor) (Kesik \& Saleff, 2009) ........................83

Figure 12-3 Roof Plan (Kesik \& Saleff, 2009) ................................................................

Figure 12-4 Structural Plan (Kesik \& Saleff, 2009) ..........................................................83

Figure 12-5 Front and Side Elevations (Kesik \& Saleff, 2009) ............................................ 84

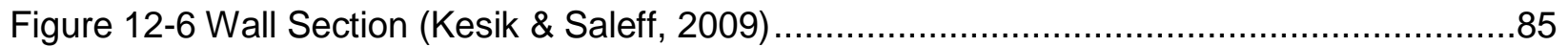

Figure 12-7 Balcony Section (Kesik \& Saleff, 2009) ……..................................................86

\section{List of Appendices}

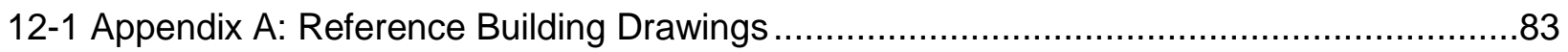

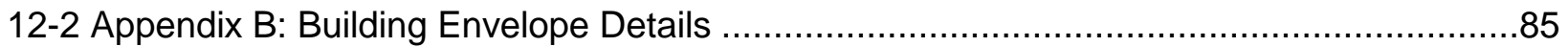

12-3 Appendix C: Building Envelope Requirements of Ontario Building Code 2012 _.................87

12-4 Appendix D: Building Envelope Retroit Measures Analysis Resuluts ..............................89 


\section{Abbreviated Terms}

BERM: Building Envelope Retrofit Measure

CDD: Cooling Degree Day

CEP: Community Energy Plan

CWEC: Canadian Weather for Energy Calculations

EEM: Energy Efficiency Measure

EETP: Evaluation of Energy and Thermal Performance

EIFS: Exterior Insulation and Finish System

GHG: Greenhouse gas

GTAH: Greater Toronto area and Hamilton

HDD: Heating Degree Day

MURB: Multi-unit Residential Buildings

OBC: Ontario Building Code

RCM: Resource Conservation Measure

RSI: Heat resistance value based on International System of Units

R-value: Heat resistance value

SC: Shading Coefficient

SHGC: Solar Heat Gain Coefficient

U-value: Heat conductivity value

VT: Visible Transmission 


\section{Introduction}

\subsection{Research Topic}

It is important to study energy enhancement strategies in old buildings because of their high energy consumption compared to new dwellings. Studies show that the energy consumption of existing buildings in large cities accounts for up to $80 \%$ of total energy consumption by these buildings. On the contrary, new construction developments are indeed the most efficient and contribute to energy consumption by approximately $20 \%$ (Zimmermann, 2012).

Postwar multi-unit residential buildings (MURBs) in Canada are not exempt from this fact; actually, these towers are among some of the most energy-inefficient buildings. Some of the components of these buildings have reached the end of their lifecycle while others are in need of major restoration (Kesik \& Saleff, 2009). In order to improve their existing condition and upgrade the towers to become energy efficient, a revitalization plan is required.

Before the implementation of any retrofit plan, the options available must be evaluated

to ensure the best alternative is incorporated. As such, the focus of this study is to evaluate the impact of building envelope retrofits on energy consumption to forecast the outcome of this retrofit on postwar MURBs in Toronto and identify the best options available. 


\subsection{Objectives}

This study aims to evaluate the impact of building envelope retrofit options with respect to energy consumption. The prediction of final outcomes is very critical before implementation of the retrofit. The prediction can be achieved by measuring the retrofit's performance. In this study, the retrofit performance measure is the energy saved as a result of the retrofit. The energy consumption of a postwar MURB before and after the implementation of various building envelope strategies is studied to evaluate the performance of each option. This assists the designers and decision makers in deliberating a variety of building envelope retrofit choices with reference to predicted outcomes and energy-saving measures.

\subsection{Scope}

Building envelope retrofits has many benefits, one of which is energy conservation. It is essential to evaluate the savings that can be achieved from such retrofits prior to beginning such a costly project to ensure that the retrofit has the potential to meet the intended expectations. Previous research available in this area only evaluated the upgrade levels below today's codes and standards. OBC 2012 (SB-10) implies the minimum RSI values for building envelope components for new constructions. As such, this MRP attempts to identify how building envelope retrofit measures can impact the energy consumption of a postwar MURB in Toronto when the building envelope upgrades address the most current codes and standards in place.

In new buildings, the minimum thermal resistance values for each building envelope component are specified by regulations. Unlike new construction developments, there is 
a wide range of options available for the retrofit. The thermal resistance value of the retrofit projects must be carefully evaluated before application. However, increasing RSI values enhance energy conservation, but beyond a certain thickness, insulation does not have a significant impact on energy savings. The same also applies to airtightness values. Analyzing the impact of increasing the thermal resistance and airtightness on the building envelope can help to identify the optimal upgrade values. Consequently, this research attempts to investigate the optimal RSI and airtightness values for a postwar tower building. The building envelope retrofit upgrades must be reasonable and translate into a considerable amount of energy savings to make the upgrade worthwhile.

Another major consideration that plays an important role in decision making is the cost of building envelope retrofits. This retrofit is amongst the most expensive of energysaving strategies (Kesik \& Saleff, 2009). Not only is maximizing the energy conservation essential, but it is also important for the project to be cost effective. Hence, this study aims to recognize the optimal upgrade levels from energy consumption and cost points of view. The high cost associated with building envelope retrofits can be reduced if the strategies applied comply with optimal measures such as cost effectiveness and energy efficiency. Therefore, building envelope retrofit options are ranked based on their energy-efficiency measure and cost effectiveness in order to identify the optimal options available for such retrofits.

In this research, the impact of different Building Envelope Retrofit Measures (BERMs) is evaluated on an archetype postwar tower located in Toronto. The annual energy consumption analysis is based on the results of the eQUEST energy simulation program to estimate the influence of BERMs on energy savings. Ranking of the retrofits 
with regards to cost are also based on the cost analysis performed on the same building in previous research (Tower Renewal Guideline by Kesik and Saleff).

All in all, this research attempts to build on previous research by filling in the gaps from previous studies, and also by introducing new building envelope retrofit measures. The results of this study are compared with the results of previous studies in this area to identify the contribution of this research in addition to earlier research.

\subsection{Research Questions}

Forecasting building envelope retrofits benefits the decision-making process for energy, economic and environmental evaluations. As such, the research questions of this MRP are as follows:

1. How does building envelope retrofits that meet $O B C 2012$ requirements impact the energy consumption of a postwar MURB?

2. What further improvements to building envelope retrofits can be proposed to increase their impact on energy efficiency, and how can the improvement be optimized?

3. What are the best building envelope retrofit options based on cost- and energysaving measures? 


\section{Literature Review}

\subsection{Postwar MURBs Revitalization}

Due to the high demand for housing resources after the Second World War, a significant stock of high-rise buildings were constructed in Canada during the 1960s and 1970s. Postwar MURBs can be seen clustered in neighbourhoods throughout Ontario, primarily within the Greater Toronto Area and Hamilton. The concentration of these tower apartment buildings is unique in Toronto such that it takes second place, after New York, for the number of high-rises in North America (ERA Group, 2011).

Kesik and Saleff's study reported that postwar MURBs in the Greater Toronto area and Hamilton (GTAH) are among some of the most energy-inefficient buildings. The energy consumption of postwar MURBs is so high that the greenhouse gas emissions they release into the atmosphere is about one megaton annually (Kesik \& Saleff, 2009).

Preserving postwar MURBs is more beneficial for the city than reconstructing them. These towers provide affordable housing and large-size units for the tenants. Also, they were constructed utilizing a durable and strong reinforced concrete structure, which is still in good shape today. Therefore, reconstruction will take away the benefits provided by these towers to the city (Kesik \& Saleff, 2009). Revitalization of postwar MURBs not only preserves these buildings but also increases the quality of the housing and ensures occupants' health and comfort (ERA Group, 2011).

In order to validate the quality of the retrofits, the upgrade plans must be evaluated prior to implementation. The evaluations predict the outcome of the project in advance to confirm that the intended outcomes are attainable given the improvements. The focus of 
this research is the building envelope retrofit part of postwar MURBs, which is the first of retrofit essentials, and how to attain a highly predictable outcome prior to the retrofit in relation to energy conservation measures.

\subsection{Postwar MURBs Systems}

Studying postwar MURBs systems helps to better understand these buildings for a proper retrofit plan. The material and method of construction of postwar apartment buildings are unique and very similar between the 1960s and 1980s. With a slight improvement from decade to decade, the building systems remain unaffected.

\subsubsection{Structural System}

The main structure of postwar towers is reinforced concrete. The parking structures that served as the building foundations were constructed using reinforced concrete. Continuing with the same system, the above-grade structure was also reinforced concrete (columns, shear walls, slab, fire stairs and building core). Incorporating such a system, the floor slabs were also extended beyond the exterior wall to cantilever and create balconies. The exterior wall was then built on top of the floor slabs (McClelland, 2007).

\subsubsection{Building Envelope System}

Regardless of the building height and shape, the structural system and building envelope design of postwar MURBs are similar amongst all the buildings. The most common building envelope assembles for postwar MURBs are as follows:

- $100 \mathrm{~mm}$ brick veneer 
- $100 \mathrm{~mm}$ concrete block back-up tied to brick

- Asphalt impregnated building paper

- Vertical wood strapping

- Gypsum board with plaster on top

- Oil-based paint as a finish (Kesik \& Saleff, 2009)

- Some postwar buildings also have $25 \mathrm{~mm}$ of insulation

The envelope more often was built on top of floor slab, leaving the slab edges exposed to the outside. In many cases, buildings also have exposed shear wall edges penetrating through exterior walls. The balconies are either cantilevered beyond the exterior wall or the projected shear walls provide them with structural support (Kesik \& Saleff, 2009).

Another component of the building envelope is windows. The methods that windows were handled on postwar MURBs are listed below:

- The balcony windows were placed on the wall masonry and from the top they extend all the way to the underside of the concrete slab, or

- The window was implemented into the wall masonry and on top there is a loose steel lintel that supports the masonry to the underside of the slab above, or

- The window was placed on the wall masonry and it extended to the underside of the slab above, or

- The window was extended from the floor to the underside of slab above.

All windows were aluminum frame, single-glazed windows with no thermal break (Kesik \& Saleff, 2009). 
Explained above was a common construction approach for all postwar MURBs' building envelope. This construction method lacks building science theory in its original design, which is the root cause of most of the existing deficiencies at building envelope.

\subsubsection{HVAC System}

Hydronic baseboard heaters are the most common method of heating in postwar MURBs. Some buildings use electric resistance baseboard heating instead of hydronic baseboard heaters. The baseboards are located on the exterior wall beneath the windows. There is no central air conditioning provided for any of the postwar towers, and they don't have individual temperature controls in their suites (ARUP Group, 2010).

Ventilation for the individual suites is provided by infiltration and exfiltration through the building envelope, this way the fresh air is provided for the suite, replacing the exfiltrated exhaust air. Meanwhile the moisture is exfiltrated, preventing any mold from forming in the wall assembly. However, this ventilation system wastes a lot of energy due to the high amount of heat loss. The ventilation system provided for the stacked bathrooms typically consists of exhaust fans located on the roof of the building and they run continuously without any change in their operation throughout the year. The hallways are pressurized (and often pre-heated during heating season). Since there is no hood provided for the kitchen, the hallway pressurization tends to control cooking odours and smoke in the event of a fire (CMHC, 1999).

\subsection{Postwar MURBs' Existing Building Envelope Condition}

The first comprehensive review of the condition of Ontario's high-rise apartments was conducted in early 1984 by Clayton Research Associates. This research suggested that 
some repairs are required to prevent further extension of the damages with regards to building envelope including weather protection of roofs, walls and windows (Clayton Research Associates, 1984).

A 1990 CMHC study examined the potential for deterioration of the exposed reinforced concrete structures of postwar MURBs. This study concluded that there was a significant amount of carbonation in postwar MURBs' structure in Toronto, especially on the exposed reinforced balconies where the concrete and railing come in contact with each other. $\mathrm{CMHC}$ recommended prevention of the existing carbonation because when it reaches the reinforcing steel, the steel could be subjected to corrosion and the cost associated with the repair of the reinforcement in the concrete is very high (CMHC, 1990).

In 1996, Canada Mortgage and Housing Corporation published a report authored by Gerald Genge and Jacques Rousseau on required repairs on high-rise apartments in Toronto based on buildings' age. The evaluations in this report conclude that cladding, windows, roofs, balconies, garages and exposed structural elements required the most repairs (Genge \& Rousseau, 1996).

Fieldwork conducted by graduate architecture and engineering students from the University of Toronto in 2004 focused on the service condition of 1960 s and 70 s tower buildings. The result of this survey reveals that the majority of failures available in the building envelope can be found in the interfaces where two components of building envelope meet. For example, the interface where the exterior wall sits on an exposed slab, where the windows come in contact with masonry, and the contact between the 
balcony slab and railing are the areas with the most deficiencies (Kesik \& Saleff, 2009).

Aside from deterioration of the building envelope, one common problem among these buildings is the lack of insulation in the building envelope assembly. The insulation layer reduces the amount of heat loss, thus reducing the chance of condensation within the wall assembly (Kesik \& Saleff, 2009).

As stated above, there are numerous deficiencies available at the building envelope of postwar MURBs. Postponing the necessary repairs on the building envelope extended the severity of the available problems. Considering the poor existing condition of the building envelope, it is evident that the need for a proper building envelope retrofit solution is inevitable.

\subsection{Building Envelope Retrofit}

Based on the above-mentioned facts regarding deficiencies, building envelope retrofits is among the top priorities for postwar MURBs. Building envelope retrofits can address the existing problems found on the envelopes. In addition, it preserves this valuable building stock for tenants.

The factors to be considered in an effective building envelope design must address the following: structure; interior finish; vapour movement; heat flow, air leakage; and exterior finish (Straube, 2006). The existing tower buildings provide structure and interior finishes, and building envelope retrofits must provide for the rest of the requirements.

Currently, there is either no insulation or a minimum amount of insulation in the existing envelope of postwar buildings. Lack of insulation increases the heat transfer through the 
wall assembly, resulting in wasting energy (CMHC, 2006).

The insulation on the exterior prevents heat loss, keeps the assembly warm, covers the thermal bridges, reduces the chance of condensation and thus improves the hygrothermal performance of exterior wall assemblies (Craven \& Garber-Slaght, 2012).

Airtightness is also a co-benefit achieved via building envelope retrofits. Airtightness is a factor that relies on careful detailing of the wall assembly and window replacement. The air leakage will be significantly reduced through this process (Kesik \& Saleff, 2009). The impact of airtightness in high-rise MURBs is more significant than low-rise apartments due to the high-pressure gradients across the building envelope as a result of the stack effect (Touchie, Pressnail, \& Binkley, 2012). A study by CMHC reports that air leakage signifies up to $24 \%$ of annual heating consumption in MURBs, confirming its impact on energy conservation (CMHC, 2007).

All in all, building envelope retrofits preserves the structure of the building and maintains the quality of housing until other retrofit strategies are applied. It also benefits other retrofit plans such as HVAC retrofits.

\subsubsection{Opaque Elements of Building Envelope}

Exterior walls, roofs, ground floor slabs and slab edges are considered the opaque elements of building envelope. The retrofit strategy of these elements must consider the control of vapour movement, heat flow and air leakage by adding one or several layers to the existing assemblies.

The type of insulation selected for the application of over-cladding is very critical. Some insulation materials are multifunctional and some are uni-functional. The uni-functional 
insulation only addresses the issue of heat loss in an assembly, yet a multifunctional insulation acts as an air barrier as well as a vapour retarder. Where the insulation is going to be implemented can determine the type and the insulation material to be used. For example, an exterior wall, roof and foundation have specific requirements for the type of insulation to be applied (Kesik \& Saleff, 2009).

There are several insulation application methods available for exterior wall retrofits, which include the following: exterior retrofit (over-cladding), interior retrofit and cavity insulation. External insulation is usually the preferred method for adding insulation to existing buildings. It does not cause loss of interior space and tenants' dislocation. The thermal bridges and moisture problems can also be addressed with proper detailing. Air tightness is also a co-benefit of this process. It also renews the look of the building. Rigid board and spray-foam insulation are the two types of insulation preferred for overcladding. The insulation can be added on the exterior either mechanically fastened or by adhesion (Groleau, Allard, Gurracino, \& Peuportier, 2007) (Energy Efficient and Integrated Urban Development Action, 2011).

Depending on the lifecycle of a building and the roof, this assembly can likely be replaced several times. Each replacement presents an opportunity to improve the energy performance of this part of the building envelope by adding insulation. Two methods are the most common in the application of insulation to the roof of high-rise buildings: built-up roofs and inverted roofs. This can be done as part of the roof membrane replacement with both methods (CMHC, 2006).

The best option to be applied for slab insulation is the implementation of rigid or blown 
insulation to the underside of the slab (CMHC, 2006).

Another alternative to address the thermal bridge problem available at the exposed slab of the balconies is to enclose them to create a sunroom. However, the focus of this research is on the over-cladding of the slab to achieve the same RSI as the exterior wall.

\subsubsection{Windows}

Inefficient windows can significantly degrade the effective thermal resistance of exterior walls. The life of single-glazed windows and aging sealants of postwar MURBs have ended, thus window replacement is mandatory.

Three factors must be considered when selecting window glass: SHGC (Solar Heat Gain Coefficient), U-value and VT (Visible Transmission). In cold climates, the highest SHGC available is recommended for south-facing façades to maximize the solar heat gain, and a less SHGC is recommended for west-facing windows to reduce the cooling demand. Higher VT values are also recommended to eliminate the necessity of using electricity consumption for lighting. Double or triple-glazed windows with low-e on the outer side of the innermost glass are the best options for cold climates (Robinson, 2013). Another important factor with regards to window frame is the minimum amount of air leakage, and the thermal break within the frame (Baker, 2012).

\subsection{Building Envelope Retrofits and HVAC System}

Building envelope retrofit planning must consider the changes it will cause to the HVAC system. This retrofit helps to reduce the heating and cooling demand of the building, 
which also downsizes the HVAC system. Furthermore, the HVAC upgrades as a result of building envelope retrofits will increase energy and cost savings (Kesik \& Saleff, 2009).

Another major concern regarding the over-cladding of tower buildings is the ventilation that was provided by air leakage. After the over-cladding and window replacement are applied, the infiltration will be practically eliminated as the envelope airtightness increases. The infiltration beneath the suite doors also can't provide sufficient fresh air for the units (CMHC, 1999). Consequently, the corridor ventilation system must be reconfigured to supply fresh air to each suite. With this system the heat from the exhaust air can be recovered to achieve further energy savings (CMHC, 2003). Adding a heat recovery ventilation system to the existing building requires some modification to the existing equipment and ductwork. Fresh air and exhaust air ducts must be provided for each individual unit, and the heat recovery equipment also has to be added to the system to recover heat from the exhaust. In order to maximize the benefit of the heat recovery system, the heat must be recovered from all the exhaust air leaving the building. The heat recovered from this system is then used to pre-heat the fresh air supplied to each individual unit.

Although there is no central air conditioning system at postwar towers, efficient window systems along with proper shading devices can significantly reduce the cooling demand. Dehumidification is also another strategy that can reduce the demand for cooling. The fresh air provided to the suites can be cooled and dehumidified in the new system. All in all, the impact of building envelope retrofits on HVAC systems has a positive outcome for the building. 


\subsection{Building Envelope Retrofits and Energy Efficiency}

Building envelope plays a major role in determining cooling and heating requirements, thus impacting the energy use of a building. Increasing the heat resistance properties of building envelope components and airtightness are amongst the strategies to upsurge the impact of building envelope on energy efficiency. Building envelope retrofits on existing buildings applies the same strategies to achieve energy conservation. This research focuses on some of the main studies that evaluate the impact of building envelope retrofits of postwar building on energy efficiency.

\subsubsection{Postwar MURBs Studies}

MURBs' energy use intensity reported by different studies varies significantly. The average results for the $\mathrm{CMHC}$ studies are summarized in Table 2-1 for both natural gas and electrically heated buildings (CMHC, 1999) (CMHC, 2000) (CMHC, 2005).

Table 2-1 Annual energy use intensity for typical tower buildings located in Toronto, Ontario (Kesik \& Saleff, 2009)

\begin{tabular}{ll}
\hline Energy Use Intensity per $\mathrm{m}^{2}$ & $322.5 \mathrm{ekWh} / \mathrm{m}^{2}$ \\
\hline Energy Use Intensity per Suite & $30,823 \mathrm{ekWh} /$ suite
\end{tabular}

Research done by Yirong Huang from Ryerson University establishes the most recent and comprehensive database available in Canada in reference to the energy benchmarking of postwar MURBs in Toronto. This study evaluates the energy consumption of 45 gas-heated and 1 electric-heated buildings built between 1962 and 1984. The annual energy consumption of these buildings was weather normalized utilizing PRISM software based on 30 years of Toronto weather data. This study reports that the normalized energy consumption of gas-heated buildings ranges from 242 to 
$453 \mathrm{kWh} / \mathrm{m}^{2}$. The mean energy consumption of these MURBs was found to be 336 $\mathrm{kWh} / \mathrm{m}^{2}$. The electric-heated building has a normalized consumption value of 174 $\mathrm{kWh} / \mathrm{m}^{2}$ (Huang, 2012). The mean energy consumption at gas-heated buildings reported by Huang's study is very close to the average energy intensity stated by the CMHC study.

A detailed energy analysis performed by Natural Resources Canada in 2003 on a 1960 archetype tower also approves of the result of averaged MURBs' energy use intensity reported by CMHC. Figure 2-1 indicates the energy use intensity of the 1960 archetype tower before and after a comprehensive retrofit. The energy intensity was reduced from the existing value of $310 \mathrm{ekWh} / \mathrm{m}^{2}$ to $94 \mathrm{ekWh} / \mathrm{m}^{2}$, a reduction of $69.7 \%$. This research reveals that a $69.7 \%$ reduction is possible with building envelope retrofits coupled with HVAC system retrofits (Kesik \& Saleff, 2009).

This result indicates that the over-cladding strategy provides for energy-saving potential along with the HVAC retrofit, but does not indicate the contribution of each strategy separately to identify their share in savings.

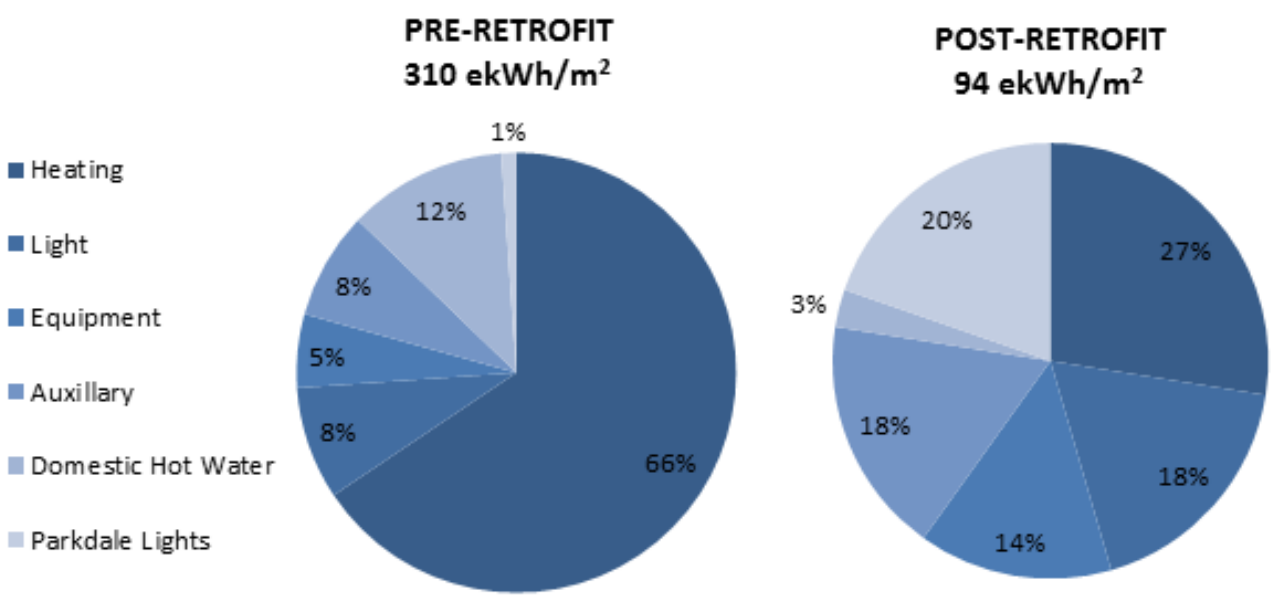

Figure 2-1 Breakdown of energy use in the archetype tower building before and after retrofit (Kesik \& Saleff, 2009) 
The Tower Renewal Guideline book by Kesik and Saleff conducted a study on the same archetype tower. There are 15 Resource Conservation Measures (RCMs) described in Kesik and Saleff's research. The first $8 \mathrm{RCMs}$ are related to building envelope retrofit measures and the rest focus on HVAC, electrical, water and comprehensive retrofit measures. The building envelope RCMs are as follows:

- RCM 1: Replace existing roof with RSI 3.5 roof

- RCM 2: Overclad with RSI 2.1 (excluding balcony and shear walls)

- RCM 3: Overclad walls with RSI 2.8 (excluding balcony and shear walls)

- RCM 4: Replace existing windows with RSI 0.44 units

- RCM 5: Enclose balconies with RSI 0.44 glazing and RSI 2.64 for opaque walls

- RCM 6: Overclad walls with RSI 2.8 and balconies with RSI 1.76

- RCM 7: Overclad walls with RSI 2.6 and balconies with RSI 1.76 and windows replacement

- RCM 8: Enclose balconies with RSI 0.44 glazing, RSI 2.64 guard, overclad walls with RSI 2.8 and window replacement

This analysis is based on NRCan's Screening Tool energy simulation. The results of the RCMs are presented in terms of electricity, natural gas and water consumption savings with a focus on life cycle cost analysis. The capital cost of each RCM was calculated along with its reduced energy cost in order to figure out the annual cost savings and its payback time as a result of each RCM.

Since the primary focus of this study is cost savings, the improvement levels are compared in terms of paybacks (HVAC retrofits has the lowest and over-cladding has 
the highest paybacks).

Amongst the 8 building envelope RCMs, replacement of an existing roof with RSI 3.5 has the lowest payback time followed by replacing existing windows with RSI 0.44 units; with 11.5 years for roofs and 13.5 years for window replacement, respectively. Overcladding exterior walls with RSI 2.8 and balconies with RSI 1.76 have the longest payback period, which is 24.5 years. A building envelope retrofit strategy including overcladding walls with RSI 2.6 and balconies with RSI 1.76 along with window replacement by units with RSI 0.44 has a payback period of 23.3 years (not including the roof retrofit). Table 2-2 illustrates the result of this study in terms of payback time (Kesik \& Saleff, 2009).

Table 2-2 Life cycle cost assessment of building envelope RCMs (Kesik \& Saleff, 2008)

\begin{tabular}{cccc}
\hline $\begin{array}{c}\text { Building Envelope } \\
\text { RCMs }\end{array}$ & $\begin{array}{c}\text { Payback with Current } \\
\text { Energy } \\
\text { Escalation Rate (years) }\end{array}$ & $\begin{array}{c}\text { Payback with High } \\
\text { Energy } \\
\text { Escalation Rate (years) }\end{array}$ & $\begin{array}{c}\text { Annual } \mathrm{CO}_{2} \\
\text { Credit (kg) }\end{array}$ \\
\hline RCM 1 & 11.42 & 10.65 & 83614 \\
RCM 2 & 17.07 & 15.55 & 146867 \\
RCM 3 & 18.12 & 16.44 & 163858 \\
RCM 4 & 13.5 & 12.48 & 382650 \\
RCM 5 & 21.03 & 18.87 & 363279 \\
RCM 6 & 24.52 & 21.74 & 469271 \\
RCM 7 & 23.28 & 20.72 & 648250 \\
RCM 8 & 18.6 & 16.84 & 703412 \\
\hline
\end{tabular}

Though the study on Tower Renewal Guideline touches on the role of building envelope on energy conservation, the comparison is mostly focused on payback periods. This study does not compare the impact of RCMs based on energy-saving measures such as gas or electricity savings; rather, the comparison is based on cost and payback time. Some important factors such as the impact of ground floor slab insulation, comprehensive building envelope retrofit and airtightness are also discarded in this 
study.

Another study by Arup Group looks at 3 building sites located in the GTA. Arup Group proposed a Community Energy Plan (CEP) to improve energy efficiency in postwar tower residential communities. The Arup study introduced $30 \mathrm{RCMs}$ with reference to reducing the consumption of electricity, natural gas and water. The goal of this study is to update the previous study performed by Kesik and Saleff, using eQUEST energy modelling software. The eQUEST results reflect the current capital costs and utility rate increases. Actual data collected from these buildings was used for the purpose of energy modelling (ARUP Group, 2010).

Five RCMs in this study deal with building envelope options:

- RCM 1: Re-caulking around windows to reduce infiltration

- RCM 2: Installing double pane windows and balcony doors

- RCM 3: Cladding exterior walls with RSI 3.17, non-enclosed balconies

- RCM 4: Cladding exterior walls with RSI 3.17, enclosed balconies

- RCM 5: Solarwall ventilation preheat system

The results of this study express that building envelope retrofit benefits natural gas consumption more than electricity consumption. It also reveals that among these five RCMs, cladding the exterior wall has the most impact and can reduce natural gas consumption by an average of $30 \%$. Window replacement, re-caulking around windows and Solarwall systems can also benefit natural gas consumption by an average of $8 \%$, $6 \%$ and $3.5 \%$, respectively. Table $2-3$ below illustrates the results of the Arup study on energy consumption of the pilot sites (ARUP Group, 2010) (It should be noted that 
airtightness values as a result of re-caulking around windows are not mentioned in the Arup study).

Table 2-3 Potential building envelope resource conservation measure (RCM) summary (ARUP Group, 2010)

\begin{tabular}{|c|c|c|c|c|}
\hline \multicolumn{2}{|c|}{$\begin{array}{c}\text { Building Envelope } \\
\text { RCMs }\end{array}$} & $\begin{array}{c}\text { Electricity Savings } \\
\text { (\% of kWh/yr) }\end{array}$ & $\begin{array}{c}\text { Natural Gas Savings } \\
\left.\text { (\% of } \mathrm{m}^{3} / \mathrm{yr}\right)\end{array}$ & $\begin{array}{l}\text { Carbon Reduction } \\
\text { (Tonnes/yr) }\end{array}$ \\
\hline \multirow{3}{*}{ RCM 1} & BLG 1 & $0 \%$ & $5 \%$ & 83 \\
\hline & BLG 2 & $0 \%$ & $8 \%$ & 88 \\
\hline & BLG 3 & $1 \%$ & $6 \%$ & 76 \\
\hline \multirow{3}{*}{ RCM 2} & $\mathrm{BLG} 1$ & $0 \%$ & $8 \%$ & 123 \\
\hline & $\mathrm{BLG} 2$ & $0 \%$ & $13 \%$ & 144 \\
\hline & BLG 3 & $1 \%$ & $4 \%$ & 146 \\
\hline \multirow{3}{*}{ RCM 3} & BLG 1 & $0 \%$ & $36 \%$ & 554 \\
\hline & BLG 2 & $0 \%$ & $30 \%$ & 326 \\
\hline & BLG 3 & $3 \%$ & $15 \%$ & 186 \\
\hline \multirow{3}{*}{ RCM 4} & $\mathrm{BLG} 1$ & $0 \%$ & $36 \%$ & 554 \\
\hline & $\mathrm{BLG} 2$ & $0 \%$ & $30 \%$ & 326 \\
\hline & BLG 3 & $3 \%$ & $15 \%$ & 186 \\
\hline \multirow{3}{*}{ RCM 5} & BLG 1 & $-2 \%$ & $4 \%$ & 51 \\
\hline & BLG 2 & $-2 \%$ & $5 \%$ & 51 \\
\hline & BLG 3 & $-1 \%$ & $2 \%$ & 25 \\
\hline
\end{tabular}

The 5 RCMs mentioned in the Arup study are very limited in comparison to the opportunities available for energy conservation via building envelope retrofits. Each assembly such as roofs, windows and doors, exterior walls and ground floor slabs plays a role in determining building envelope performance in relation to heat loss and consequently energy conservation. Moreover, the Arup study doesn't deal with the impact of each assembly on overall energy saving.

A study by the University of Toronto evaluates the relationship between MURBs from the 1960s, 1970s and 1980s and their energy use to assess energy retrofit options for postwar buildings of different ages. Comprehensive research was conducted on selected buildings using eQUEST energy simulation modelling based on actual energy use data. A series of building envelope retrofit measures were then tested on the 
models to estimate their impact on the energy consumption of the buildings. The study results reveal that retrofits with the highest energy-saving measures were boiler efficiency upgrades, airtightness upgrades and over-cladding the exterior wall assembly (not including exposed slab edges) (Touchie, Pressnail, \& Binkley, 2012).

This is the only study that takes the improvement of all building envelope assemblies into account except for the ground floor slab. The building envelope RCMs in this research are as follows:

- Airtightness of envelope: $1.53,1.02,0.76,0.51$ and $0.255 \mathrm{l} / \mathrm{sm}^{2}$

- Windows: Double-glazed low-e and Triple-glazed low-e

- Exterior insulation: 50-76 mm polystyrene insulation

- Roof insulation: 25-100 mm polystyrene insulation

Table 2-4 below illustrates the changes on energy consumption of the buildings as a result of RCMs.

Table 2-4 Influence of building envelope RCMs insulation on energy intensity (Touchie, Pressnail, \& Binkley, 2012)

\begin{tabular}{|c|c|c|c|c|c|}
\hline \multicolumn{2}{|c|}{$\begin{array}{c}\text { Building Envelope } \\
\text { RCMs }\end{array}$} & $\begin{array}{l}\text { BLG } 1 \\
1960 \mathrm{~s}\end{array}$ & $\begin{array}{c}\text { BLG } 2 \\
1970 s\end{array}$ & $\begin{array}{l}\text { BLG } 3 \\
1970 \mathrm{~s}\end{array}$ & $\begin{array}{l}\text { BLG } 4 \\
1980 \mathrm{~s}\end{array}$ \\
\hline & & Ene & Saving & $\%$ of ekl & $\left./ m^{2}\right)$ \\
\hline \multirow{6}{*}{ Airtightness of envelope } & $0.255 \mathrm{l} / \mathrm{sm}^{2}$ & 24 & 18 & 9 & 7 \\
\hline & $0.51 \mathrm{l} / \mathrm{sm}^{2}$ & 21 & 15 & 4 & 3 \\
\hline & $0.76 \mathrm{l} / \mathrm{sm}^{2}$ & 17 & 11 & Base & Base \\
\hline & $1.02 \mathrm{l} / \mathrm{sm}^{2}$ & 14 & 8 & 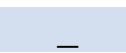 & 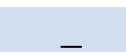 \\
\hline & $1.53 \mathrm{l} / \mathrm{sm}^{2}$ & 7 & Base & - & - \\
\hline & $2.04 \mathrm{l} / \mathrm{sm}^{2}$ & Base & 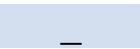 & & - \\
\hline \multirow{3}{*}{ Windows } & Single Glazed & Base & & Base & \\
\hline & Double Glazed & 6.8 & Base & 21 & Base \\
\hline & Triple Glazed & 7.2 & 1 & 23 & 1 \\
\hline \multirow{3}{*}{ Exterior Walls } & $0 \mathrm{~mm}$ & Base & & & \\
\hline & $50 \mathrm{~mm}$ & 5 & Base & Base & Base \\
\hline & $76 \mathrm{~mm}$ & 7 & 3 & 2 & 2 \\
\hline
\end{tabular}




\begin{tabular}{cccccc}
\hline & $25 \mathrm{~mm}$ & Base & & & \\
& $38 \mathrm{~mm}$ & - & Base & - & Base \\
\multirow{3}{*}{ Roof } & $50 \mathrm{~mm}$ & 1.5 & 0.8 & - & \\
& $76 \mathrm{~mm}$ & 2.2 & 2.4 & Base & 2 \\
& $100 \mathrm{~mm}$ & 2.8 & 3.9 & 1 & 4 \\
\hline
\end{tabular}

It was found that reducing the air leakage in a relatively loose building envelope can result in building energy savings of up to $24 \%$. Window replacement can also result in maximum savings of $23 \%$ depending on the window-to-wall ratio of the building. The impact of window upgrades from single-glazed to double-glazed is significant, but from double-glazed to triple-glazed is very small. By adding $50 \mathrm{~mm}$ of exterior insulation to exterior walls of 1960's buildings - which had the lowest level of insulation - the reduction in total annual energy use was $7 \%$. The study results also demonstrate that the saving achieved from roof insulation depends on the building size, roof area and existing RSI value of the roof. Therefore, the percentage saving varies amongst the buildings for roof upgrades (Touchie, Pressnail, \& Binkley, 2012).

Touchie's research reveals a great amount of information on the impacts of upgrades to each of the building envelope assemblies. This study does not compare the impact of comprehensive building envelope retrofits with other strategies. Moreover, the evaluation does not discuss the optimal values in thermal resistance or the airtightness since the proposed upgrade levels are limited. This study does not consider the cost of retrofit strategies either.

\subsection{Building Envelope Retrofits and Cost}

Building envelope retrofit measures can significantly reduce the energy demand of postwar MURBs. However, the applications of such strategies are very costly and have 
long payback periods. The initial capital costs of such projects are very high compared to energy cost savings from a retrofit, which results in the long payback time. If these strategies are implemented while the building is being renovated for other reasons or during repair or replacement projects, the energy cost savings can help to recover the capital costs faster (CMHC, 2006).

Cost effectiveness and shorter payback times are important factors in the application of building envelope retrofits. Kesik and Saleff's report looks into cost analyses of building envelope retrofit measures. This study presents a case of roof insulation, over-cladding exterior walls and balconies, window replacement, balcony enclosure, coupled building envelope retrofit strategies and comprehensive building envelope retrofits (without the insulation of ground floor slabs). The building's annual energy consumption is estimated before and after the application of each building envelope retrofit strategy. The capital cost of each project is also estimated, and the payback period and internal rates of return are calculated based on the energy cost savings calculated from energy modelling. Interest rates of $4 \%$ and $6 \%$ were used, which represent low and high interest rate scenarios, respectively. This study incorporates inflation rates of $2.4 \%$ and $4 \%$ above the inflation points (Kesik \& Saleff, 2009).

Kesik and Saleff's study reveals that over-cladding walls and balconies is the most expensive project; after that, window replacements have the highest initial cost amongst the strategies and roof insulation is the most inexpensive option. This study does not evaluate the impact of ground floor insulation (Kesik \& Saleff, 2009).

Another important factor is the payback period of the project. The payback period also 
has a relationship with energy-saving measures. Energy conservation as a result of building envelope retrofits reduces the cost associated with energy consumption of the building; consequently, the more energy cost savings, the shorter the payback period is if they have identical initial capital costs (Kesik \& Saleff, 2009).

The results of energy-saving measures along with the payback time based on high energy escalation rates of each retrofit strategy from Kesik and Saleff's research is summarized in Table 2-5 below. As can be seen, roof insulation has the shortest payback period, then window replacement and at last over-cladding walls and balconies.

Table 2-5 Results of energy saving and payback time of Kesik and Saleff's Study

\begin{tabular}{ccc}
\hline RCMs & $\begin{array}{c}\text { NRCan Screening Tool } \\
\text { Energy Saving }\end{array}$ & $\begin{array}{c}\text { Payback } \\
\text { Period }\end{array}$ \\
\hline Roof Insulation & $6 \%$ & $10.65-11.42$ \\
Window Replacement & $28 \%$ & $12.48-13.5$ \\
Over-cladding walls and balconies & $26.5 \%$ & $21.74-24.52$ \\
Ground Floor Insulation & - & - \\
Comprehensive Building Envelope \\
Retrofit
\end{tabular}

Another important factor to consider here is the option of combining the building envelope retrofit strategies and comprehensive building envelope retrofits. The result of the NRCan Screening Tool in the Tower Renewal Guideline report reveals that combining the building envelope retrofit strategies results in more energy savings (Table 2-2). Kesik and Saleff's cost analysis results also demonstrates that the payback period of comprehensive building envelope retrofits is almost the same as (or less than) overcladding walls and balconies (which has the longest payback period) (Kesik \& Saleff, 2009). Accordingly, comprehensive building envelope retrofits is a more cost-effective 
option, considering the energy-efficiency measure and payback period. However, a drawback from this option is the initial capital cost of this project, which is higher than any other building envelope retrofit option.

If the RSI value of the components increases, the cost associated with the strategy also increases. The result of the Crawley study reveals that the application of the lowest levels of insulation has a higher payback time compared to higher thermal resistance values with the same insulation material. It is only cost effective to increase the RSI value when the existing building envelope components have a very low thermal resistance value. The increase of RSI values should be such that it does not exceed the optimal thickness thermal resistance value (Crawley, N/A).

In addition to the high cost associated with building envelope retrofits, the cost of HVAC retrofits will also be added. Replacement of the boilers, addition of the ductwork and heat recovery equipment are the factors that cost money. Nevertheless, installation of smaller and more efficient HVAC systems along with heat recovery increases energy cost savings, which helps to reduce the payback period of the retrofits altogether (CMHC, 2006).

The cost analysis in Kesik and Saleff's report reveals that replacement of the existing boiler with a more efficient option will result in energy savings of $27 \%$ and has a payback period of about 5 years. Incorporating ducted fresh air supply to each individual unit with $70 \%$ heat recovery from return air will result in $22 \%$ energy efficiency with a payback period of about 4 years (Kesik \& Saleff, 2009).

If a building envelope and HVAC retrofit are implemented together on a building, since 
the payback period of the HVAC is very short compared to the building envelope, the energy cost saving associated with the HVAC retrofit starts to pay off the expenses, thus shortening the payback period of the project as a whole.

As an example, the cost-saving analysis in Kesik and Saleff's study reports a payback period of 18.2 to 20.2 years for a comprehensive building envelope retrofit (not including ground floor slab insulation) with boiler replacement, heat recovery, water and lighting retrofit (Kesik \& Saleff, 2009). This payback period is less than the over-cladding payback period, which is due to the short payback period associated with HVAC, water and lighting retrofit that starts to pay off the expenses for building envelope retrofits by its high-energy cost-saving value.

In conclusion, building envelope retrofits cannot take place in isolation from HVAC retrofits; moreover, it is more economically feasible to implement both retrofits in parallel in order to have a shorter payback period for the project. Nonetheless, the major obstacle for such an approach is the initial capital cost of this project, which is very high. 


\section{Methodology}

In this study, the impact of a building envelope retrofit of a 20-storey archetype postwar MURB is explored. The Building Envelope Retrofit Measures (BERMs) represent upgrades to the building envelope of the archetype tower. To identify the impact of building envelope retrofits meeting OBC 2012 requirements, all building envelope components are upgraded to code standards. Further upgrades also take place to evaluate how the impact of building envelope retrofits on energy use can be increased and optimized. Finally, the cost-effective optimal strategies are evaluated. The sections below explain how this study approaches such evaluations.

\subsection{Variables}

This MRP introduces four groups of BERMs: building envelope upgrades based on OBC 2012 (SB-10) standards, incremental upgrades of building envelope components (RSI value), airtightness upgrades, combined comprehensive building envelope retrofit and airtightness upgrades. These upgrades create two types of variables: thermal resistance values of building envelope components (RSI) and airtightness value. To replicate the upgrades and evaluate their impact on energy efficiency, the RSI and airtightness measures are improved on the energy modelling software to simulate the results. The variable associated with "building envelope upgrade based on OBC 2012 (SB-10) standards" and "incremental upgrade of building envelope components" are the RSI values. Airtightness upgrades change the building envelope airtightness values on the energy modelling software. And "combined comprehensive building envelope retrofit and airtightness upgrades" deals with both variables. In the section that follows, these 
variables are explained in detail.

\subsubsection{Thermal Resistance (RSI values)}

\subsubsection{Building Envelope Upgrade Based on OBC 2012 (SB-10) Standards}

Standards and regulations such as building code define the minimum RSI value required for the components of building envelope. In Ontario, there is no compulsory standard available for the retrofit of postwar MURBs (a major renovation on a building must be code compliant).

For the purpose of this research, The Supplementary Standards of Ontario Building Code 2012 (SB-10) is assumed to be the regulation to follow for the upgrades of building envelope assemblies. Therefore, the first group of BERMs denotes an upgrade to the envelope of the archetype tower following SB-10 standards. Appendix B discloses building envelope requirements of SB-10 for a building located in Toronto.

In the first alteration strategy, upgrades of building envelope components, the RSI of each component is upgraded to match the OBC 2012 (SB-10) standards. In addition, the impact of compound and comprehensive building envelope retrofits based on OBC 2012 (SB-10) is evaluated.

At last, the influence of building envelope retrofit based on OBC 20102 (SB-10) on $\mathrm{CO}_{2}$ emission is also assessed.

\subsubsection{Incremental Upgrade of Building Envelope Components}

In the second alteration strategy, "incremental upgrade of building envelope components," the RSI value of each component is gradually increased from the 
baseline to a reasonably high RSI value by equal intervals. The maximum RSI values were selected based on the available options in energy modelling software (eQUEST). In this software, the insulation material, thickness and the location of the insulation (exterior) identifies the limitation of the RSI value to ensure it is reasonable and practical.

In the process of incremental upgrade of RSIs, the impact range of each component on energy-efficiency measures is also identified. This identifies the approximate maximum saving that can be achieved from the upgrade of one component.

Furthermore, such evaluation detects the infliction point of RSI values of each component of building envelope. There are two inflection points identified for each component. The first is the minimum RSI value defined for each component. The second is the point where the impact of increasing the RSI value of a component is significantly reduced on energy efficiency. The RSI values below the second inflection points are then defined as the optimal RSI values since their impact on energy saving is more significant than the values past this point.

\subsubsection{Building Envelope Airtightness Upgrades}

From literature review, it is evident that over-cladding and window replacement increase the airtightness of building envelope. The actual airtightness measure is dependent on design, detailing and execution efforts during the implementation of building envelope retrofit. The OBC 2012 (SB-10) does not have any specific requirements for the airtightness value of building envelope. The only way to find out the actual impact of building envelope retrofit on airtightness is to measure the infiltrations through the 
envelope before and after implementation of this retrofit. Though this is not practical for this study.

Assuming that building envelope retrofit increases the airtightness, just like the previous section "Incremental Upgrade of Building Envelope Components", the airtightness value of the archetype tower gradually increases on the energy model in order to evaluate the impact of such improvement on energy use of the building. These upgrades not only identify the influence of envelope airtightness on energy consumption of the archetype but also, the inflection point in the airtightness value is identified, suggesting the optimal value for the airtightness. The optimal values in airtightness are defined as the values below the inflection point, which results in more substantial energy savings for the building.

\subsubsection{Combined Comprehensive Building Envelope Retrofit and Airtightness Upgrades}

Combined comprehensive building envelope retrofits and airtightness upgrades deal with both thermal resistance and airtightness variables. In comprehensive building envelope retrofits, all envelope assemblies are upgraded together. After the inflection points are identified, the impact of combined comprehensive building envelope retrofits and airtightness are compared in three scenarios:

1. Comprehensive building envelope retrofit based on the minimum RSI values (inflection point 1) and airtightness value at Inflection point 1

2. Comprehensive building envelope retrofit based on the RSI values identified in Inflection point 2 and airtightness value at Inflection point 1 
3. Comprehensive building envelope retrofit based on OBS (2012 SB-10) and airtightness value at Inflection point 1

\subsection{Annual Energy Consumption Analysis}

Annual energy consumption analysis makes use of energy simulation tools. These tools consider all parts of a building that contribute to energy consumption of a building such as envelope, the HVAC system and other equipment simulating the energy consumption of a particular building in a particular climate (Yang, 2009). This simulation represents the baseline energy consumption of a building.

Upgrades to the buildings can also be simulated on the program. Comparing annual energy consumption of the upgraded model with the baseline identifies the impact and savings as a result of the retrofit.

The upgrades in this study represent improvements applied on the building envelope with regards to the variables explained above. By comparing the energy-efficiency measure of each building envelope retrofit strategy, the most effective strategy can be identified. This method helps the designers evaluate different alternatives by means of energy simulation programs and thus achieve overall building energy efficiency by selecting the best options.

\subsubsection{Software Selection}

The Quick Energy Simulation Tool (eQUEST), developed by the U.S. Department of Energy (DOE), is used to model the energy performance of the archetype tower in this study. eQUEST is a building energy simulation software available to the public. Since 
eQUEST is fast, inexpensive and accurate, this software is commonly adopted by the industry. With the ability to adapt to different input levels, this program can conduct a whole-building energy simulation. eQUEST is easy to use, and has "wizards" and help menus that assist the modeller (U.S. Department of Energy, 2010). Considering the above-mentioned reasons and also that previous studies used this software, eQUEST was chosen to model the MURB in this study.

\subsubsection{Data Collection and Base Case Energy Model Generation}

ASHRAE 90.1 defines the base case energy model as: "A computer representation of a hypothetical design based on the proposed building project. This representation is used as the basis for calculating the baseline building performance for rating above-standard design." (ASHRAE, 2013, p. 3)

To create a base case energy model of a building on eQUEST, the building information such as drawings, building envelope system and HVAC system must be available. Natural Resources Canada provides this information on the archetype tower building in the Tower Renewal Guideline Report by Kesik and Saleff. The baseline annual energy consumption of the archetype tower (electricity consumption and gas consumption) is also reported in this study (Kesik \& Saleff, 2009).

An important part in the energy modelling process is "Calibration." In the calibration process, the default input variables on the model are adjusted so that the simulation results are similar to the actual annual energy consumption of a building (Touchie, Pressnail, \& Binkley, 2012).

The baseline eQUEST energy model for this study was simulated using the information 
presented in the Tower Renewal Guideline Report. The model was calibrated so that the gas and electricity use intensity of the model is close to previously reported values in Kesik and Saleff's study.

The calibration of the eQUEST model for this research is via the airtightness measure of the building. Since the actual measured airtightness of the building is not available, an airtightness value that represents a leaky building has been used. The airtightness value was adjusted until the natural gas consumption intensity of the model was similar to the natural gas consumption intensity reported in the Tower Renewal Study. The airtightness measure was found to be $2.04 \mathrm{l} /\left(\mathrm{s} \cdot \mathrm{m}^{2}\right)$. This value represents a very leaky building envelope. The airtightness of the archetype building is comparable to the airtightness value of a 1960's building from Touchie's study, confirming this result (Touchie, Pressnail, \& Binkley, 2012).

All available data were incorporated into the model. The unknown input values are estimated from the available drawings and information provided in the Tower Renewal Guideline Report as close as possible, wherever needed. For any other unknown parameters, eQUEST default values were implemented. The model was then run using the Canadian Weather for Energy Calculations file for Toronto.

\subsubsection{BERMs Energy Model Generation}

Using the base case model, various retrofit measures are evaluated based on their energy performance. In each BERM, one criteria of building envelope has changed on the baseline model (as explained in the Variables section) to evaluate its contribution on energy intensity of the building. A percentage decrease in energy intensity has been 
presented for each BERM indicating its impact on the energy use of the building.

\subsection{Ranking the Building Envelope Retrofit Options Based On Energy- Saving Measures and Cost}

After the evaluation of BERMs based on energy-efficiency measures, 4 major building envelope retrofit strategies (roof, exterior wall and balconies, windows and ground floor slab) are compared based on their energy-efficiency measure, initial capital cost and payback period.

The ranking of the retrofit strategies in reference to energy-efficiency measures is based on the results of eQUEST energy modelling of this study. The strategy with the highest energy-efficiency measure has the highest ranking, and the one with the lowest energy savings has the lowest ranking.

The results of Kesik and Saleff's building envelope cost analysis on the archetype postwar tower are used for the capital initial cost and payback period ranking. The strategy with the highest cost has the lowest ranking, and the one with the lowest cost has the highest ranking in the initial capital cost category. In ranking the strategies based on the payback period, the strategy with the shortest payback has the highest ranking and the one with the highest payback has the lowest ranking.

The results of the 3 ranking categories for each strategy are then added together. The strategy with the highest value is identified as the most effective and the one with the lowest value is identified as the least effective from a cost and energy effectiveness point of view.

In order to illustrate the impact of the different priorities in different projects, the ranking 
is done once with all categories having the same weight and once with the energyefficiency measure having priority over initial capital cost and payback period. The ranking identifies the most cost- and energy-efficient options available, and helps the designer select the most optimal strategy based on the priorities of the project. 


\section{Building Details}

Based on the explanation in section 2.2, the reference building is consistent with vintage high-rise residential towers of Toronto. A summary of the basic building characteristics determined from drawings, NRCan, Tower Renewal Guideline reports and other sources is provided in Table 4-1, which also represents the data input in eQUEST energy modelling software. Figure 4-1 and Figure 4-2 illustrate the typical floor plan and axonometric view of the archetype tower.

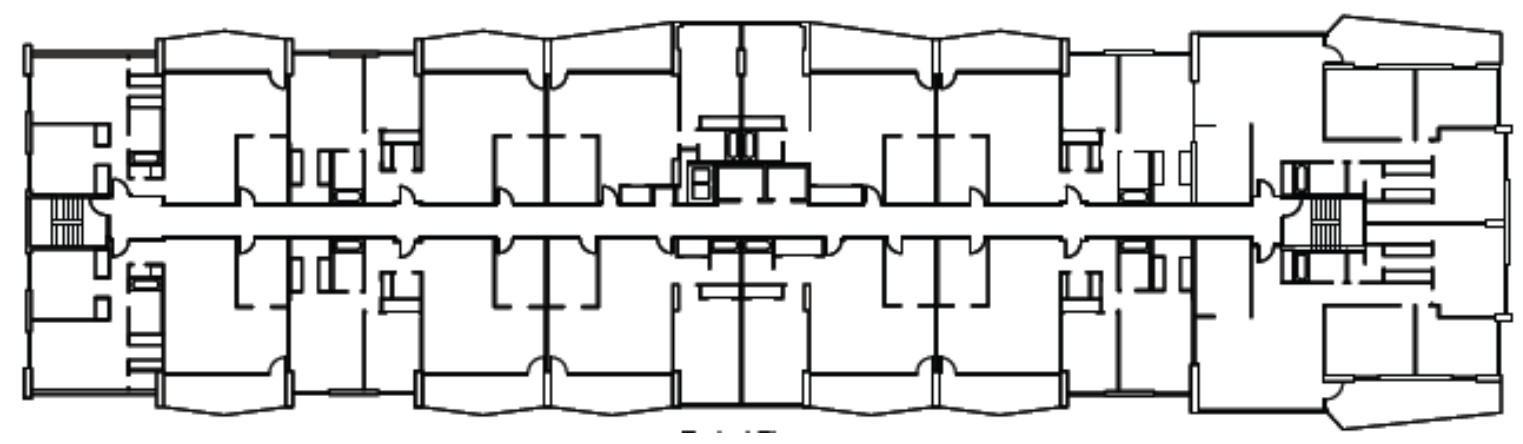

Figure 4-1 A typical floor plan of the archetype tower (Kesik \& Saleff, 2009)

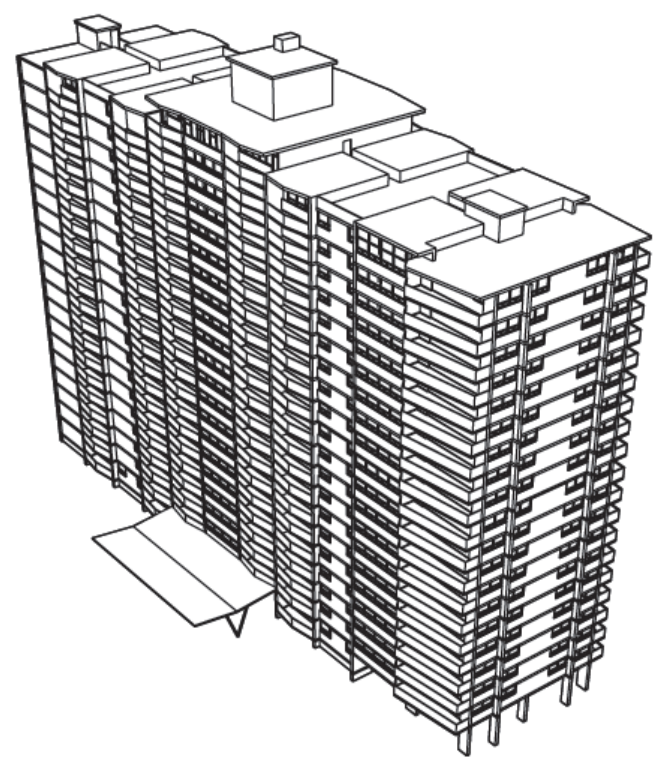

Figure 4-2 Axonometric view of the archetype tower (Kesik \& Saleff, 2009) 
Table 4-1 Building characteristics (Kesik \& Saleff, 2008)

\begin{tabular}{|c|c|}
\hline Year & 1960 \\
\hline Size & $\begin{array}{l}\text { - } \quad 20 \text { above-ground floors } \\
\text { - } \quad 236 \text { units } \\
\text { - } \quad 73.2 \mathrm{~m} \times 18.3 \mathrm{~m} \text { : } \\
\text { - } \quad \text { Gross Floor Area: } \\
\text { - } \quad 23360 \mathrm{~m}^{2} \\
\text { - } \quad \text { Building Height: } 58 \mathrm{~m} \\
\text { - } \quad \text { Floor-to-floor height: } 2.73 \mathrm{~m} \\
\text { Floor-to-Ceiling height: } 2.43 \mathrm{~m}\end{array}$ \\
\hline Exterior Wall & $\begin{array}{l}\text { - } 10 \mathrm{~cm} \text { clay brick } \\
\text { - } \quad 2.5 \mathrm{~cm} \text { collar joint } \\
\text { - } 10 \mathrm{~cm} \text { hollow } \\
\text { - } \quad \text { Concrete block } \\
\text { - } \quad \text { Building paper } \\
\text { - } \quad 1 \times 2 \text { Wood strapping } \\
\text { - } \quad \text { Foiled-back gypsum lath } \\
\text { - } \quad 1 \mathrm{~cm} \text { plaster finish } \\
\text { - } \quad \text { Slabased paint }\end{array}$ \\
\hline Roof & $\begin{array}{l}\text { - } 20.23 \mathrm{~cm} \text { concrete } \\
\text { - } \quad \text { Roof built up, Black and Flat } \\
\text { - } \quad \text { Exterior Insulation RSI } 1.4\left(\mathrm{~m}^{2} \mathrm{C} / \mathrm{W}\right)\end{array}$ \\
\hline $\begin{array}{l}\text { Ground Floor } \\
\text { Slab }\end{array}$ & $\begin{array}{l}\text { - } \quad 20.23 \mathrm{~cm} \text { concrete } \\
\text { - } \quad \text { No insulation }\end{array}$ \\
\hline Airtightness & - $\quad 2.04 \mathrm{l} .\left(\mathrm{sm}^{2}\right)$ \\
\hline Windows & $\begin{array}{l}\text { - } \quad \text { Single-glazed aluminum frame } \\
\text { - USI } 5\left(\mathrm{~W} / \mathrm{m}^{2} \mathrm{C}\right) \\
\text { - } \quad 26.5 \% \text { window-to-wall ratio }\end{array}$ \\
\hline Interior Loads & $\begin{array}{ll}\text { - } & \text { Interior lighting } \\
\text { - } & \text { Cooking } \\
\text { - } & \text { Refrigerators } \\
\text { - } & \text { Laundry } \\
\text { - } & \text { Miscellaneous }\end{array}$ \\
\hline Heating & $\begin{array}{l}\text { - Hydronic Baseboard Radiators } \\
\text { - } \quad \text { Hot water boiler to feed radiators } \\
\text { - } 60 \% \text { Efficiency } \\
\text { - } \quad \text { Boiler temperature set point } 66^{\circ} \mathrm{C} \\
\text { - } \quad \text { Winter interior temperature set point } 21^{\circ} \mathrm{C}\end{array}$ \\
\hline Cooling & - No central cooling \\
\hline Ventilation & $\begin{array}{l}\text { - Unconditioned Make-up air units for Corridor } \\
\text { - } \quad \text { Hallway pressurization } \\
\text { - } \quad \text { No heat recovery }\end{array}$ \\
\hline $\begin{array}{l}\text { Domestic Hot } \\
\text { Water }\end{array}$ & $\begin{array}{l}\text { - } \text { Boilers } \\
\text { - } \quad \text { Temperature set point of } 66^{\circ} \mathrm{C} \\
\text { - } \text { Boiler efficiency } 60 \%\end{array}$ \\
\hline
\end{tabular}




\section{Building Envelope Retrofit Measures (BERMs)}

The building envelope retrofit measures chosen can be categorized into four groups:

1) Upgrade of building envelope components based on OBC 2012 (SB-10)

2) Incremental upgrade of building envelope components

3) Airtightness upgrades and

4) Comprehensive Building Envelope Retrofit and Airtightness

Table 5-1 illustrates base case and the details of each BERM.

Table 5-1 Building envelope retrofit measures

\begin{tabular}{|c|c|c|c|}
\hline Groups & Element Retrofit & Base Case & Retrofit Range \\
\hline \multirow{11}{*}{ Group 1* } & BERM 1-Roof & $1.40\left(\mathrm{~m}^{2} \mathrm{C} / \mathrm{W}\right)$ & $5.20\left(\mathrm{~m}^{2} \mathrm{C} / \mathrm{W}\right)$ \\
\hline & BERM 2-Fenestrations & $0.20\left(\mathrm{~m}^{2} \mathrm{C} / \mathrm{W}\right)$ & $0.50\left(\mathrm{~m}^{2} \mathrm{C} / \mathrm{W}\right)$ \\
\hline & BERM 3-Exterior Walls & $0.6\left(\mathrm{~m}^{2} \mathrm{C} / \mathrm{W}\right)$ & $3.50\left(\mathrm{~m}^{2} \mathrm{C} / \mathrm{W}\right)$ \\
\hline & BERM 4-Balcony/Slab Edges & $0.16\left(\mathrm{~m}^{2} \mathrm{C} / \mathrm{W}\right)$ & $3.50\left(\mathrm{~m}^{2} \mathrm{C} / \mathrm{W}\right)$ \\
\hline & BERM 5-Ground Floor Slab & $0.16\left(\mathrm{~m}^{2} \mathrm{C} / \mathrm{W}\right)$ & $3.50\left(\mathrm{~m}^{2} \mathrm{C} / \mathrm{W}\right)$ \\
\hline & BERM 6-Exterior Walls & $0.6\left(\mathrm{~m}^{2} \mathrm{C} / \mathrm{W}\right)$ & $3.50\left(\mathrm{~m}^{2} \mathrm{C} / \mathrm{W}\right)$ \\
\hline & and Balcony/Slab & $0.16\left(\mathrm{~m}^{2} \mathrm{C} / \mathrm{W}\right)$ & $3.50\left(\mathrm{~m}^{2} \mathrm{C} / \mathrm{W}\right)$ \\
\hline & BERM 7-Exterior Walls & $0.6\left(\mathrm{~m}^{2} \mathrm{C} / \mathrm{W}\right)$ & $3.50(\mathrm{~m} 2 \mathrm{C} / \mathrm{W})$ \\
\hline & and Balcony/Slab & $0.16\left(\mathrm{~m}^{2} \mathrm{C} / \mathrm{W}\right)$ & $3.50(\mathrm{~m} 2 \mathrm{C} / \mathrm{W})$ \\
\hline & and Fenestrations & $0.20\left(\mathrm{~m}^{2} \mathrm{C} / \mathrm{W}\right)$ & $0.50\left(\mathrm{~m}^{2} \mathrm{C} / \mathrm{W}\right)$ \\
\hline & $\begin{array}{l}\text { BERM 8-Comprehensive building } \\
\text { envelope retrofit }\end{array}$ & . & - \\
\hline \multirow{6}{*}{ Group $2^{* *}$} & BERM 9- 14 Roof Upgrades & $1.40\left(\mathrm{~m}^{2} \mathrm{C} / \mathrm{W}\right)$ & $\begin{array}{l}2.11,3.17,4.24 \\
5.28,7.39 \\
\left(\mathrm{~m}^{2} \mathrm{C} / \mathrm{W}\right)\end{array}$ \\
\hline & BERM 15- 21 Exterior wall Upgrades & $0.6\left(\mathrm{~m}^{2} \mathrm{C} / \mathrm{W}\right)$ & $\begin{array}{l}1.05,1.58,2.11, \\
2.46,3.17,3.69, \\
4.2\left(\mathrm{~m}^{2} \mathrm{C} / \mathrm{W}\right)\end{array}$ \\
\hline & & & $\begin{array}{l}\text { Double-glazed } \\
0.36,0.44,0.55, \\
0.65\left(\mathrm{~m}^{2} \mathrm{C} / \mathrm{W}\right) \\
\text { Triple Glazed }\end{array}$ \\
\hline & $\begin{array}{l}\text { BERM 22- } 29 \text { Window Upgrades with } \\
\text { Aluminum frame with no thermal break }\end{array}$ & $0.20\left(\mathrm{~m}^{2} \mathrm{C} / \mathrm{W}\right)$ & $\begin{array}{l}0.46,0.48,0.56 \\
0.83\left(\mathrm{~m}^{2} \mathrm{C} / \mathrm{W}\right) /\end{array}$ \\
\hline & & & $\begin{array}{l}\text { Aluminum } \\
\text { window frame } \\
\text { with no thermal } \\
\text { break }\end{array}$ \\
\hline & BERM 30- 37 Window Upgrades with & $0.20\left(\mathrm{~m}^{2} \mathrm{C} / \mathrm{W}\right)$ & Double-glazed \\
\hline
\end{tabular}




\begin{tabular}{|c|c|c|c|}
\hline & Aluminum frame with thermal break & & $\begin{array}{l}0.36,0.44,0.55, \\
0.65\left(\mathrm{~m}^{2} \mathrm{C} / \mathrm{W}\right) \\
\text { Triple Glazed } \\
0.46,0.48,0.56, \\
0.83\left(\mathrm{~m}^{2} \mathrm{C} / \mathrm{W}\right) / \\
\text { Aluminum } \\
\text { window frame } \\
\text { with insulated } \\
\text { thermal break }\end{array}$ \\
\hline & $\begin{array}{l}\text { BERM 38- } 45 \text { Window Upgrades with } \\
\text { Insulated fiberglass frame with thermal } \\
\text { break }\end{array}$ & $0.20\left(\mathrm{~m}^{2} \mathrm{C} / \mathrm{W}\right)$ & $\begin{array}{l}\text { Double-glazed } \\
0.36,0.44,0.55, \\
0.65\left(\mathrm{~m}^{2} \mathrm{C} / \mathrm{W}\right) \\
\text { Triple Glazed } \\
0.46,0.48,0.56, \\
0.83\left(\mathrm{~m}^{2} \mathrm{C} / \mathrm{W}\right) / \\
\text { Insulated } \\
\text { fiberglass } \\
\text { window frame } \\
\text { with insulated } \\
\text { thermal break }\end{array}$ \\
\hline & $\begin{array}{l}\text { BERM 46- } 52 \text { Ground Floor Slab } \\
\text { Upgrades }\end{array}$ & $0.16\left(\mathrm{~m}^{2} \mathrm{C} / \mathrm{W}\right)$ & $\begin{array}{l}0.7,1.4,2.1 \\
2.8,3.5,4.2,4.9 \\
\left(m^{2} \mathrm{C} / W\right)\end{array}$ \\
\hline Group 3** & BERM 53- 58 & $2.04 \mathrm{l} /\left(\mathrm{sm}^{2}\right)$ & $\begin{array}{l}1.53,1.02,0.51 \\
0.255,0.127 \\
0.06, \mathrm{l} /\left(\mathrm{sm}^{2}\right)^{\star * *}\end{array}$ \\
\hline Group $4^{* * * *}$ & BERM 59- 61 & $\begin{array}{l}\text { Existing } \\
\text { Building }\end{array}$ & $\begin{array}{l}\text { Upgrade of all } \\
\text { components and } \\
\text { airtightness }\end{array}$ \\
\hline
\end{tabular}

* OBC 2012 (SB-10)/ANSI/ASHRAE/IESNA Standard 90.1. Energy Efficiency Design After December 31, 2011 (Applies to construction for which a permit has been applied for after December 31, 2011)

* In group 1, some BERMs include the upgrade of one building envelope component only, yet some include the upgrade of more than one component.

${ }^{* *}$ In groups 2 and 3, all upgraded values are revealed in the retrofit range.

*** The lowest airtightness measures are only considered to evaluate the impact of airtightness measures and in practice these measures are very hard to achieve.

${ }^{* * * *}$ In group 4, comprehensive building envelope retrofit is combined with airtightness. More details about the specific upgrade values of this group are provided in section 6.4. 


\section{Study Results}

The following sections detail how each retrofit measure was analyzed in reference to their impact on energy consumption of the building using eQUEST energy modelling software. In the annual energy consumption analysis, modelling results are presented in terms of energy intensity so that the building can be directly compared to other study results. Further, electricity and natural gas intensities are separated so that the impact of a retrofit measure on a particular utility can be determined. For each retrofit measure, percentage improvement levels for energy intensity relative to the baseline are presented in the figures that follow.

\subsection{Building Envelope Upgrades Based On OBC 2012 (SB-10)}

This section attempts to estimate the impact of building envelope retrofit measures by upgrading all the components to the current standards. The building envelope regulations dictated by Ontario Building Code 2012 has formed the building envelope retrofit measures (BERM) for each assembly in the first group of upgrades.

In BERM1 the existing $1.40\left(\mathrm{~m}^{2} \mathrm{C} / \mathrm{W}\right) \mathrm{RSI}$ of the roof assembly has been upgraded to $5.2\left(\mathrm{~m}^{2} \mathrm{C} / \mathrm{W}\right)$ as OBC $2012(\mathrm{SB}-10)$ requires.

The e single-glazed windows and balcony doors with the RSI of $0.20\left(\mathrm{~m}^{2} \mathrm{C} / \mathrm{W}\right)$. The existing windows are considered aluminum frame operable windows with no thermal break, shading coefficient (SC) of 0.5 , visible transmission (VT) of 0.8 and no coating. The window-to-wall ratio (WWR) of this building is $26.5 \%$. OBC requires a building with WWR of $0 \%-40 \%$ and max SHGC of 0.4 to have minimum RSI of $0.50\left(\mathrm{~m}^{2} \mathrm{C} / \mathrm{W}\right)$. The replaced windows in BERM 2 are modelled as double-glazed, air infill, operable 
windows with clear glass, low-e coating and aluminum frame.

BERM 3 improves the RSI of the existing exterior walls of the archetype from no insulation to RSI $3.5\left(\mathrm{~m}^{2} \mathrm{C} / \mathrm{W}\right)$ as required by code. The study building was modelled improving the RSI of existing exposed slab edges similar to exterior walls. Insulating only the slab edges would not be considered a typical retrofit option but the associated impacts on energy intensity reductions are included in BERM4. This BERM clarifies the importance of avoiding thermal bridges in buildings.

BERM5 represents the improvement of slab insulation by RSI of $3.5\left(\mathrm{~m}^{2} \mathrm{C} / \mathrm{W}\right)$ as $\mathrm{OBC}$ 2012 (SB-10) requires.

In order to evaluate the impact of some of the retrofit options compounded together, some BERMs represent the upgrade of more than one assembly at the building envelope. BERM6 includes the retrofit of exterior wall assembly and slab edges/balcony, and BERM7 addresses the retrofit of exterior wall assembly, balcony and slab edges, and fenestration. Finally, BERM 9 represents a comprehensive building envelope retrofit in reference to current standards and regulations.

Both the baseline energy intensity and the difference in energy intensity between the baseline and the retrofit cases are illustrated in Figure 6-1. The percentage values indicate the improvement levels from the baseline. 


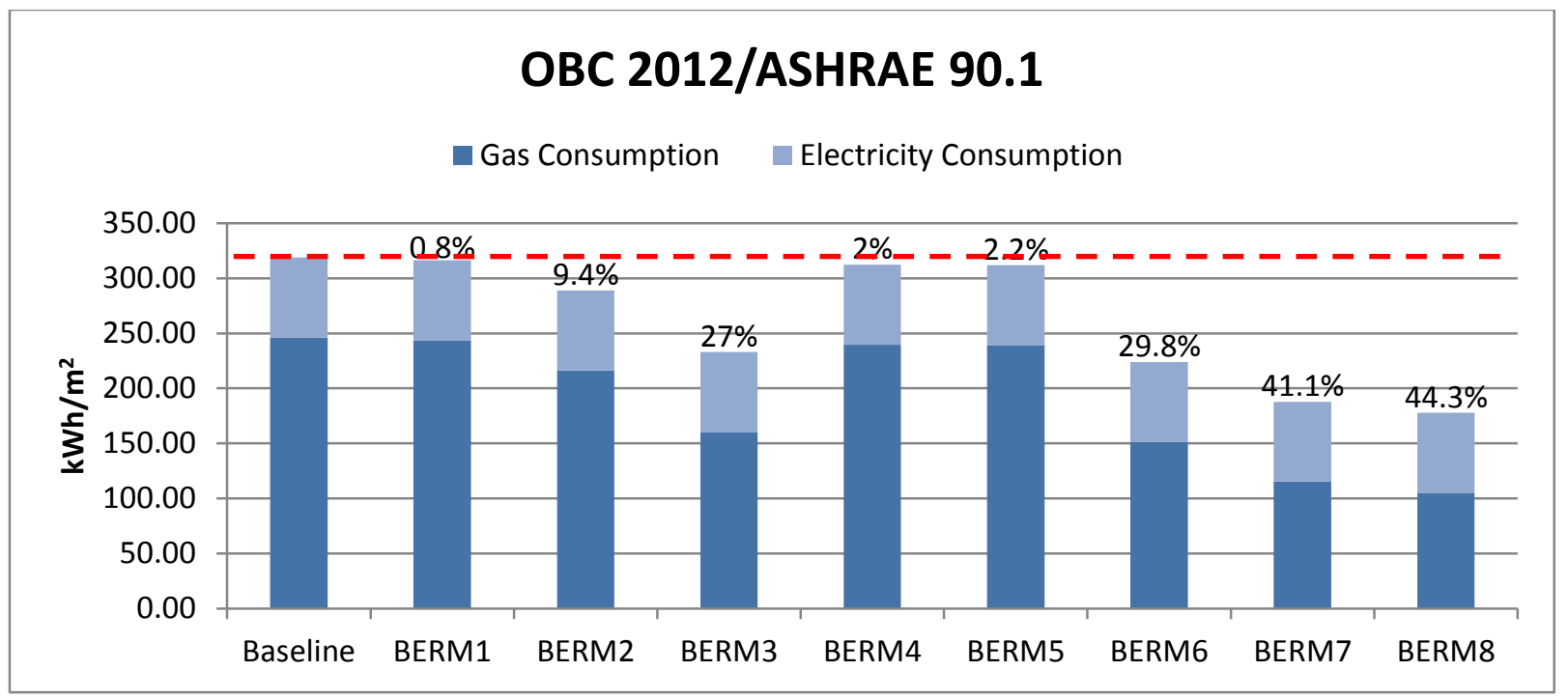

Figure 6-1 Annual energy consumption intensity analysis of upgrades of building envelope components based on OBC 2012

Most of the energy savings shown in Figure 6-1 can be attributed to a reduction in natural gas space heating. Electricity savings are negligible in comparison to natural gas savings since their impact on energy intensity was found to be less than $0.4 \%$ (refer to Appendix D for results). The reduction in electricity consumption is due to the decrees of fan and motor operation since the heating demand declines.

Aside from comprehensive building envelope retrofit (BERM8) with $44.3 \%$ reduction in energy intensity, (BERM 3) with $27 \%$ reduction has the most energy conservation benefit. The impact of window and door upgrades (BERM2) follows (BERM3) with a 9.4\% reduction. The roof upgrade (BERM1) has the least impact on energy intensity, which is $0.8 \%$, because roof heat losses make up a smaller proportion of the total building heat losses in the base case. The same scenario applies to ground floor slabs (BERM5), however, the ground floor insulation has more impact on energy efficiency than the roof with a $2.2 \%$ reduction. 
Figure 6-1 demonstrates how thermal bridges are significant components of building heat loss. Assuming the slab edge makes up $5 \%$ of a building envelope, by insulating slab edges (BERM4) of a building, a $2 \%$ reduction in total building heat loss results.

The compound BERM options also have a great impact on energy efficiency. An exterior wall and balcony/slab edge over-cladding (BERM6) have the potential to reduce energy consumption of the building by $29.8 \%$. If an exterior over-cladding coupled with window replacement (BERM7) is applied on the archetype building, this retrofit option can drop the energy consumption of the building by $41.1 \%$. A comprehensive building envelope retrofit based on $\mathrm{OBC} 12$ requirements can result in energy savings of $44.3 \%$.

\subsubsection{Annual $\mathrm{CO}_{2}$ Credit}

This section summarizes the energy savings associated with each measure and presents the associated greenhouse gas (GHG) emissions reductions. The GHG emission calculations are based on the following factors (City of Toronto, 2012):

- Electricity: $0.15 \mathrm{~kg} / \mathrm{kWh}$ (accounting for peak energy)

- Natural gas: $1.879 \mathrm{~kg} / \mathrm{m}^{3}$

The energy content of natural gas was assumed to be $10.3 \mathrm{ekWh} / \mathrm{m}^{3}$ resulting in a natural gas emission factor of $0.182 \mathrm{~kg} / \mathrm{kWh}$ (Touchie, Pressnail, \& Binkley, 2012).

Table 6-1 below summarizes the annual $\mathrm{CO}_{2}$ credit as a result of building envelope retrofits based on OBC 2012 (SB-10): 
Table 6-1 Annual CO2 credit

\begin{tabular}{ccc}
\hline BERMs & Energy Saving (\%) & Annual $\mathrm{CO}_{2}$ Credit $(\mathrm{kg})$ \\
\hline BERM1 & & 10850.17 \\
BERM2 & $0.80 \%$ & 127247.83 \\
BERM3 & $9.39 \%$ & 365051.94 \\
BERM4 & $26.93 \%$ & 27537.04 \\
BERM5 & $2.03 \%$ & 29446.19 \\
BERM6 & $2.17 \%$ & 404054.05 \\
BERM7 & $29.81 \%$ & 556975.08 \\
BERM8 & $41.09 \%$ & 600051.89 \\
\hline
\end{tabular}

The annual $\mathrm{CO}_{2}$ credit follows the same pattern as energy efficiency. The greater the influence of a BERM on energy efficiency, the more annual $\mathrm{CO}_{2}$ credit will result. Generally, building envelope retrofits based on OBC 2012 (SB-10) can reduce the $\mathrm{CO}_{2}$ emission from 10.8 tons from roof insulation up to 600 tons from a comprehensive building envelope retrofit.

\subsection{Incremental Upgrade of Building Envelope Components}

Since the OBC (2012 SB-10) does not stipulate the thermal resistance values for the upgrade of building envelopes in retrofit projects, the options available are endless. The RSI values selected for each assembly must result in a reasonable amount of saving. Increasing the thermal resistance value reduces the heat transfer, which results in energy efficiency. However, an important fact to remember is that the performance benefit of insulation is reduced beyond a certain thickness. As a result, if the thermal resistance of insulation is beyond its optimal point, the cost of the project increases without achieving a significant increase in energy efficiency. This also increases the payback period. Thus it is essential to identify the optimal thermal resistance values for each component of the building envelope to ensure that the project accomplishes 
energy savings and cost effectiveness (Kesik \& Saleff, 2009).

Another important fact to consider is the limitations with regards to the thickness for the application of over-cladding. The insulation needs to be mechanically fastened to the existing wall assembly or by means of adhesion. The higher RSI values are thus hard to achieve as they require thicker insulation, unless some advanced insulation materials are incorporated. An example is vacuum insulation; however, incorporating these materials is very costly and also has limitations in terms of application (One Journal, 2010).

To evaluate the impact, the RSI value of each component was gradually increased from the baseline up to a reasonably high value by equal intervals. Since the upgrade is from a low to a high value, consequently the impact range of each component on energyefficiency measures is also identified along with the inflection points in the RSI value of each component.

The influences of BERMs are evaluated relative to the baseline. The figures that follow represent baseline energy intensity as well as the difference in energy intensity between the baseline and the retrofit cases. The percentage values indicate the improvement levels from the baseline.

\subsubsection{Roof Upgrades}

The typical RSI value of the roof in Canadian high-rises is about $3.5\left(\mathrm{~m}^{2} \mathrm{C} / \mathrm{W}\right)$. These values are much lower than $\mathrm{OBC}$ requirements for roof assembly (CMHC, 2006).

In this study, the RSI of the existing roof of the archetype tower increased from the 
original $\mathrm{RSI}$ value of $1.4\left(\mathrm{~m}^{2} \mathrm{C} / \mathrm{W}\right)$ to $2.11,3.17,4.24,5.28,6.34$ and $7.39\left(\mathrm{~m}^{2} \mathrm{C} / \mathrm{W}\right)$.

BERMs 9 to 14 represent the upgrades to the roof assembly; Table 6-2 shows RSI values of roof upgraded BERMs, and Figure 6-2 illustrates the improvement on energy consumption as a result of such upgrades on the postwar archetype building.

Table 6-2 RSI values of roof upgrade BERMs

\begin{tabular}{ccccccc}
\hline BERMs & BERM9 & BERM10 & BERM11 & BERM12 & BERM13 & BERM14 \\
\hline $\begin{array}{c}\text { RSI } \\
\left(\mathrm{m}^{2} \mathrm{C} / \mathrm{W}\right)\end{array}$ & 2.11 & 3.17 & 4.24 & 5.28 & 6.34 & 7.39 \\
\hline
\end{tabular}

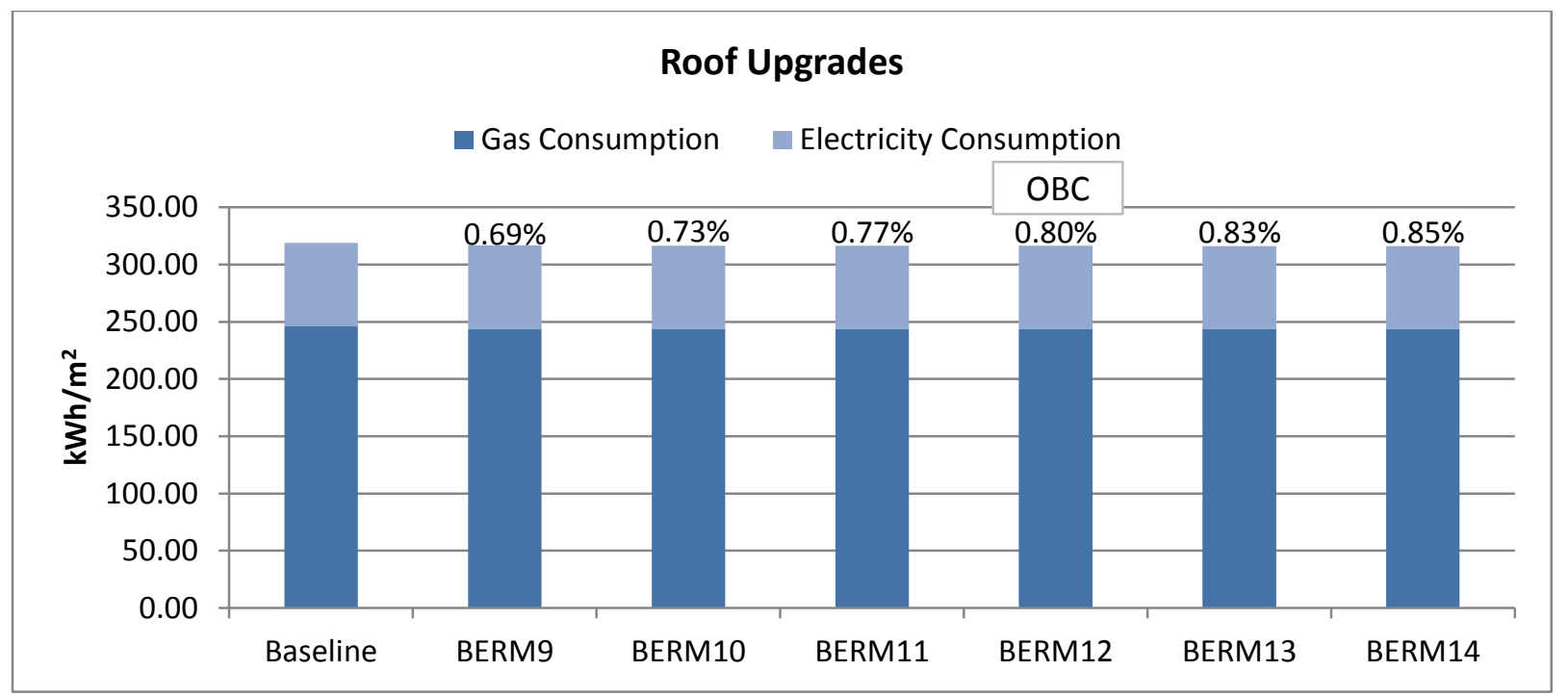

Figure 6-2 Roof upgrades

As demonstrated in Figure 6-2, the impact of roof insulation on the archetype tower is very small and can be increased up to $0.85 \%$ via superinsulating the roof. The impact margin of roof insulation on energy efficiency of this building is from $0.69 \%$ to $0.85 \%$ based on the minimum and maximum RSI values defined in this study.

Figure 6-3 below shows the roof RSI upgrade curve. The first inflection point is observed to be the first upgrade from the baseline. BERM 10 with RSI value of 
$2.11\left(\mathrm{~m}^{2} \mathrm{C} / \mathrm{W}\right)$ has a very low $\mathrm{RSI}$ value compared to the OBC 2012 (SB-10) requirement for roof assembly. Up to BERM11 the increase in energy efficiency from one BERM to the other is above $0.04 \%$, but from BERM11 this value starts to drop to $0.0 .03 \%$. Though the impact of roof upgrades is found to be negligible, the second inflection point was found to be on RSI $4.24\left(\mathrm{~m}^{2} \mathrm{C} / \mathrm{W}\right)$, which is slightly lower than what the code standard is. The RSI values between inflection point 1 and 2 are the most optimal values for roof insulation as the improvement achieved from these values are more prominent than the values after inflection point 2 (BERM 9 to 11). Moreover, since these values are less or equal to code standard, their application is practical and thus cost effective. Both inflection points are marked with a red arrow on the curve below with the location of OBC RSI standard.

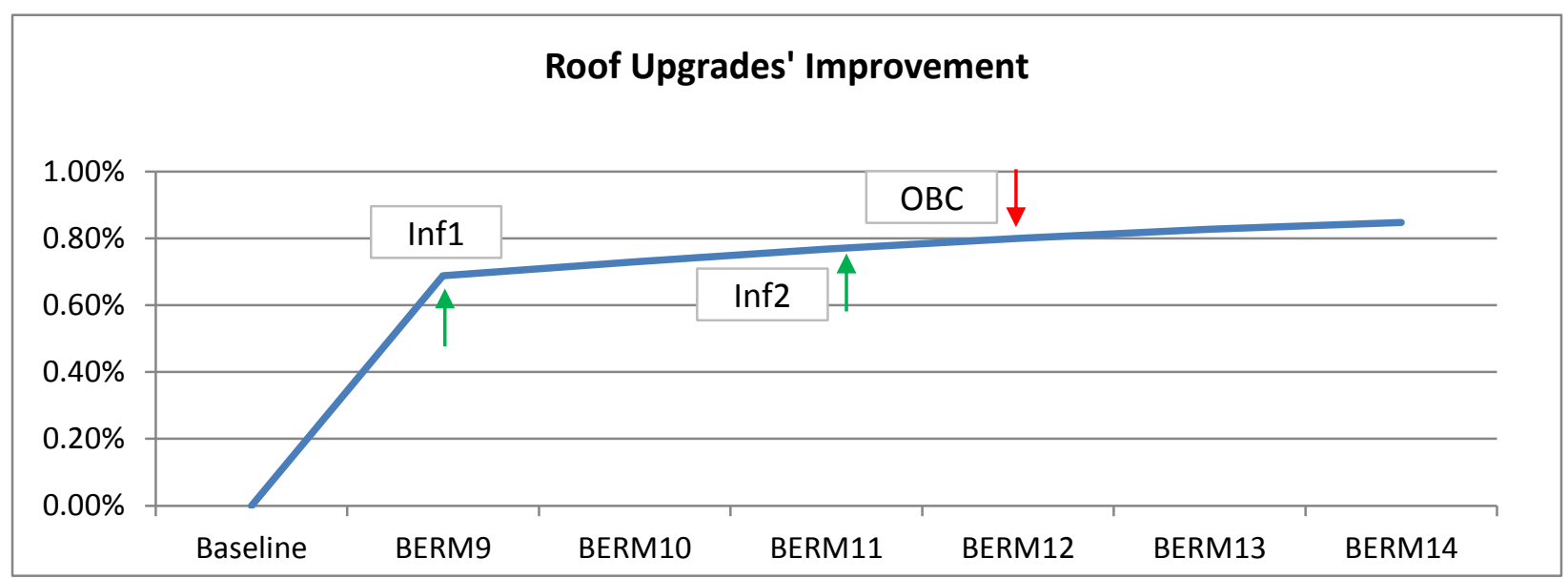

Figure 6-3 Roof upgrade curve

\subsubsection{Exterior Wall and Slab/Balcony Edges Upgrades}

The most common RSI value for the exterior wall of high-rise buildings in Canada ranges from 1.5 to $2.5\left(\mathrm{~m}^{2} \mathrm{C} / \mathrm{W}\right)(\mathrm{CMHC}, 2006)$. 
The RSI value of exterior walls and slab/balcony edges are increased from the baseline, with an RSI of $0.6\left(\mathrm{~m}^{2} \mathrm{C} / \mathrm{W}\right)$ for exterior walls and $0.16\left(\mathrm{~m}^{2} \mathrm{C} / \mathrm{W}\right)$ for slab/balcony edges, to $1.05,1.58,2.11,2.46,3.17,3.5$ and $4.2\left(\mathrm{~m}^{2} \mathrm{C} / \mathrm{W}\right)$.

Based on the National Energy Code for Buildings' recommendations, the RSI value of 4.2 is beyond the suggested margin (CMHC, 2006). This value is only selected to evaluate the impact of a value beyond code standards.

RCM 15 to 21 represents the upgrades to the exterior wall assembly and slab/balcony edges. Table 6-3 shows the RSI values of over-cladding exterior walls and slab/balcony edges. Figure 6-4 illustrates the result of exterior wall assembly and slab/balcony edges upgrades and its impact on energy efficiency (These values represents the upgrade of both exterior wall and slab/balcony edges).

Table 6-3 RSI Values of over-cladding exterior wall and balcony slab upgrade BERMs

\begin{tabular}{cccccccc}
\hline BERM S & BERM15 & BERM16 & BERM17 & BERM18 & BERM19 & BERM20 & BERM21 \\
\hline $\begin{array}{c}\text { RSI } \\
\left(\mathrm{m}^{2} \mathrm{C} / \mathrm{W}\right)\end{array}$ & 1.05 & 1.58 & 2.11 & 2.46 & 3.17 & 3.69 & 4.2 \\
\hline
\end{tabular}

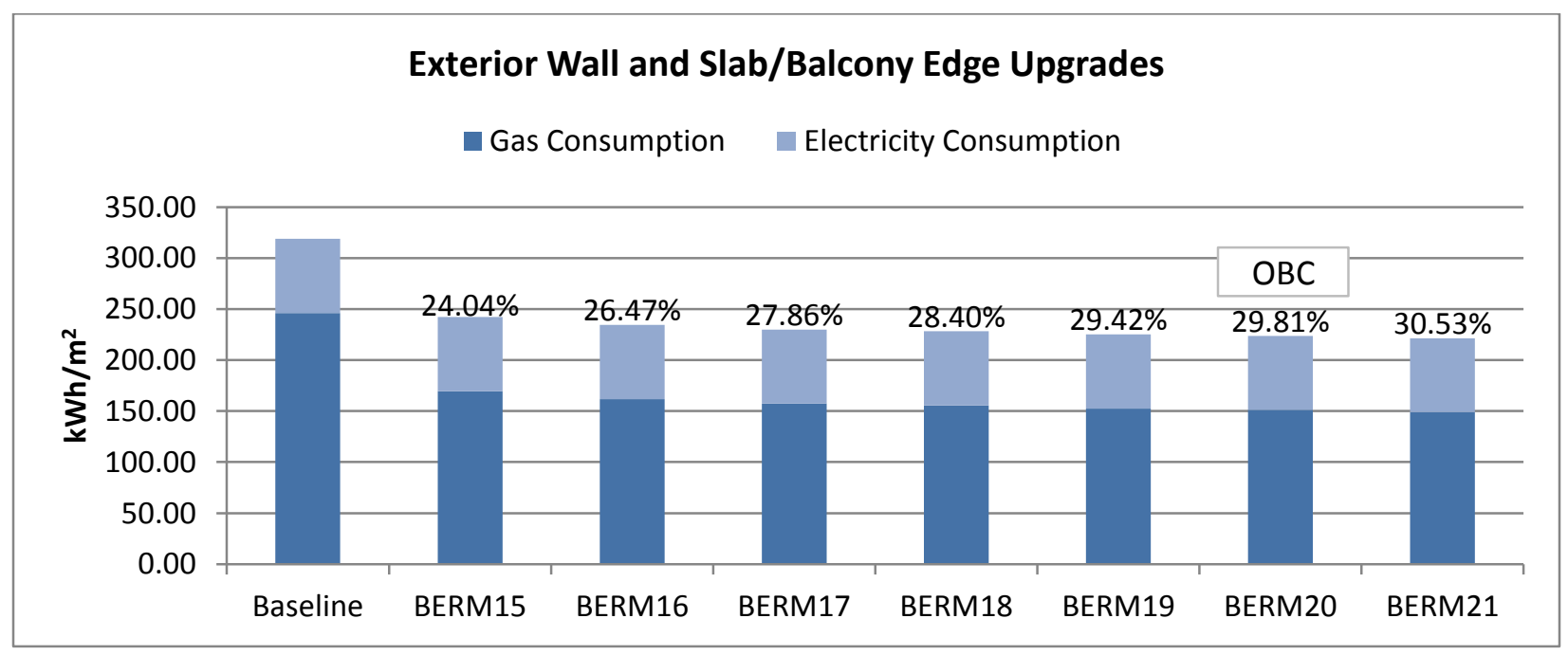

Figure 6-4 Exterior wall and balcony/slab edges upgrades 
From Figure 6-4, it can be concluded that based on the minimum and maximum values introduced by this study for the upgrade of the exterior wall assembly and slab/balcony edges, an impact range of $24.04 \%$ to $35.53 \%$ on energy efficiency is expected from this strategy.

Figure 6-5 below shows the RSI upgrade curve of the exterior wall and balcony/slab edges. Since the exterior wall lacks insulation in the existing assembly, the first upgrade with an RSI of $1.4\left(\mathrm{~m}^{2} \mathrm{C} / \mathrm{W}\right)$ (inflection point 1) has the most impact on energy use. Additionally, over-cladding the exposed balcony/slab edges minimizes the existing thermal bridges and heat loss. Nevertheless, RSI 1.4 is below the requirements of OBC 2012 (SB-10), and with the high cost associated with over-cladding, it is only reasonable to achieve higher energy-saving measures to make the project worthwhile.

From BERM 15 up to BERM 19, energy efficiency improves by $1 \%$ from each upgrade. From BERM 19 to BERM 20, the increase in energy efficiency drops to $0.4 \%$. As a result, the second inflection point in the exterior wall and balcony/slab edges upgrades curve is BERM19 with an RSI value of $3.17(\mathrm{~m} 2 \mathrm{C} / \mathrm{W})$, which is slightly below what OBC 2012 (SB-10) demands for exterior wall assembly. The optimal RSI values for exterior wall over-cladding are then found to be the values up $3.17\left(\mathrm{~m}^{2} \mathrm{C} / \mathrm{W}\right)$. These RSI values can be obtained via application of conventional insulation materials.

The inflection points are identified with red arrows on the curve below along with a green arrow representing the OBC 2012 (SB-10) RSI value for exterior wall assembly. 


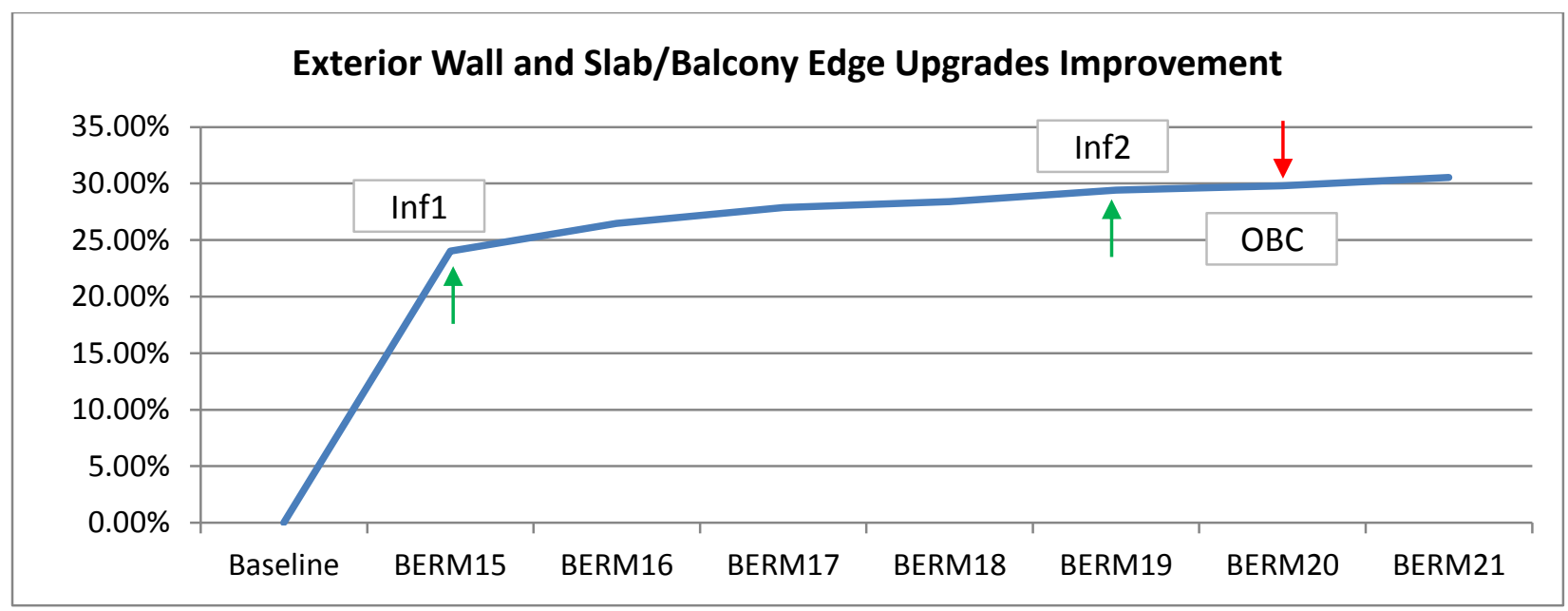

Figure 6-5 Exterior wall and balcony/slab edges upgrades curve

\subsubsection{Window Upgrades}

Windows are usually the weak points of the envelope since they have the lowest RSI value compared to other components. The overall RSI or USI value of the window depends on both the glass area and the frame. The factors that impact the USI of the glass area are the number of glass panes, the thickness of the gap between the panes, the gas infill, as well as the low e coating. The features that determine the RSI value of the frame are the material, insulation and thermal breaks in the frame. In this research, 3 types of window frames are considered with 8 different RSI values for the glass area in which the values are gradually improving from the baseline.

The 3 types of window frames are categorized as follows:

1) Aluminum window frame without a thermal break (BERM 22-29)

2) Aluminum window frame with insulated thermal break (BERM 30-37) and

3) Insulated fiberglass window frame with insulated thermal break (BERM 38-45) 
Each of these window frames is modelled with 8 different options of window glasses. The window glass RSI gradually increases from the existing single-glazed with an RSI of $0.2\left(\mathrm{~m}^{2} \mathrm{C} / \mathrm{W}\right)$ to double-glazed window with an RSI of $0.36,0.44,0.55,0.65\left(\mathrm{~m}^{2} \mathrm{C} / \mathrm{W}\right)$ and triple-glazed window with an RSI of $0.46,0.48,0.56,0.83\left(\mathrm{~m}^{2} \mathrm{C} / \mathrm{W}\right)$.

Figure 6-6 illustrates the aluminum frame window without thermal break upgrades, Figure 6-7 represents the upgrades on aluminum frame with insulated thermal break window and Figure 6-8 shows the upgrades on insulated fiberglass frame with insulated thermal break window. Table 6-4, Table 6-5 and Table 6-6 show the RSI values associated with each BERM in the window upgrade strategy.

Both the baseline energy and the difference in energy intensity between the baseline and the retrofit cases are illustrated in the figures that follow. The percentage values indicate the improvement levels from the baseline.

From Figure 6-6, Figure 6-7 and Figure 6-8, it can be concluded that based on the minimum and maximum RSI values incorporated in this study, an impact margin of $7.33 \%$ to $13.22 \%$ on energy efficiency is achievable via window replacement for the archetype tower building.

Figure 6-6 demonstrates that upgrading the glass area of the windows with the basic window frame, which is similar to the existing window frames of the building, can result in savings of $7.33 \%$ to $11.44 \%$. BERM 22 to 25 represents double-glazed windows and BERM 26 to 29 represents triple-glazed windows. Comparing the double-glazed with triple-glazed windows, on average there is about a $1 \%$ increase in energy efficiency by incorporation of triple-glazed windows. 
Table 6-4 RSI values of window upgrade BERMs with aluminum frame window without thermal break

\begin{tabular}{ccccccccc}
\hline \multirow{2}{*}{ BERMs } & BERM & BERM & BERM & BERM & BERM & BERM & BERM & BERM \\
& 22 & 23 & 24 & 25 & 26 & 27 & 28 & 29 \\
\hline \multirow{2}{*}{ RSI } & Double- & Double- & Double- & Double- & Triple- & Triple- & Triple- & Triple- \\
$\left(\mathrm{m}^{2} \mathrm{C} / \mathrm{W}\right)$ & glazed & glazed & glazed & glazed & glazed & glazed & glazed & glazed \\
& 0.36 & 0.44 & 0.55 & 0.65 & 0.46 & 0.48 & 0.56 & 0.83 \\
\hline
\end{tabular}

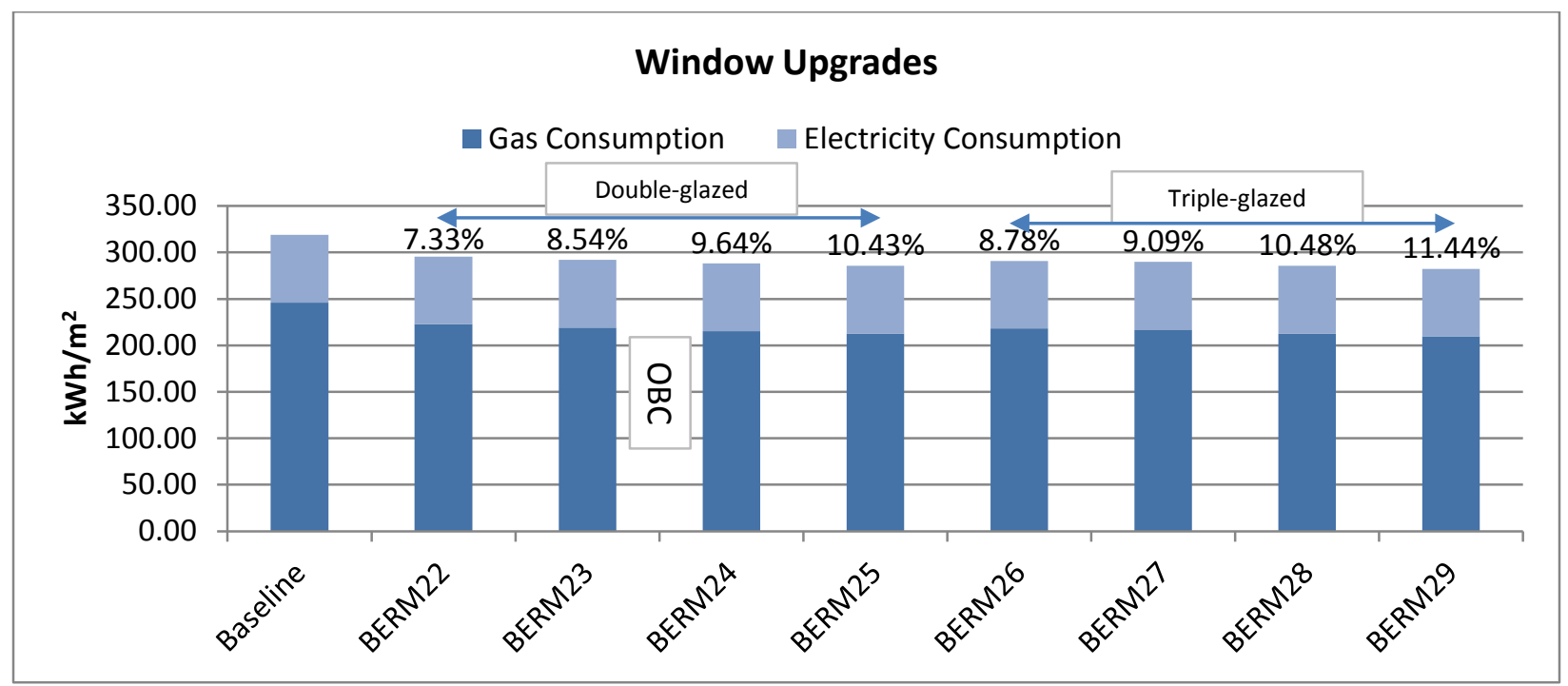

Figure 6-6 Aluminum frame without thermal break window upgrades

Figure 6-7 reveals that utilizing aluminum frame windows with insulated thermal break can result in energy savings ranging between $8.39 \%$ and $12.62 \%$. Comparing these measures with the savings in Figure 6-6, it is evident that the insulated thermal break in the aluminum window frame can increase energy efficiency by about $1 \%$, which quite significant.

Table 6-5 RSI values of window upgrade BERMs with aluminum frame window with thermal break

\begin{tabular}{ccccccccc}
\hline \multirow{2}{*}{ BERMs } & BERM & BERM & BERM & BERM & BERM & BERM & BERM & BERM \\
& 30 & 31 & 32 & 33 & 34 & 35 & 36 & 37 \\
\hline RSI & Double- & Double- & Double- & Double- & Triple- & Triple- & Triple- & Triple- \\
$\left(\mathrm{m}^{2} \mathrm{C} / \mathrm{W}\right)$ & glazed & glazed & glazed & glazed & glazed & glazed & glazed & glazed \\
& 0.36 & 0.44 & 0.55 & 0.65 & 0.46 & 0.48 & 0.56 & 0.83 \\
\hline
\end{tabular}




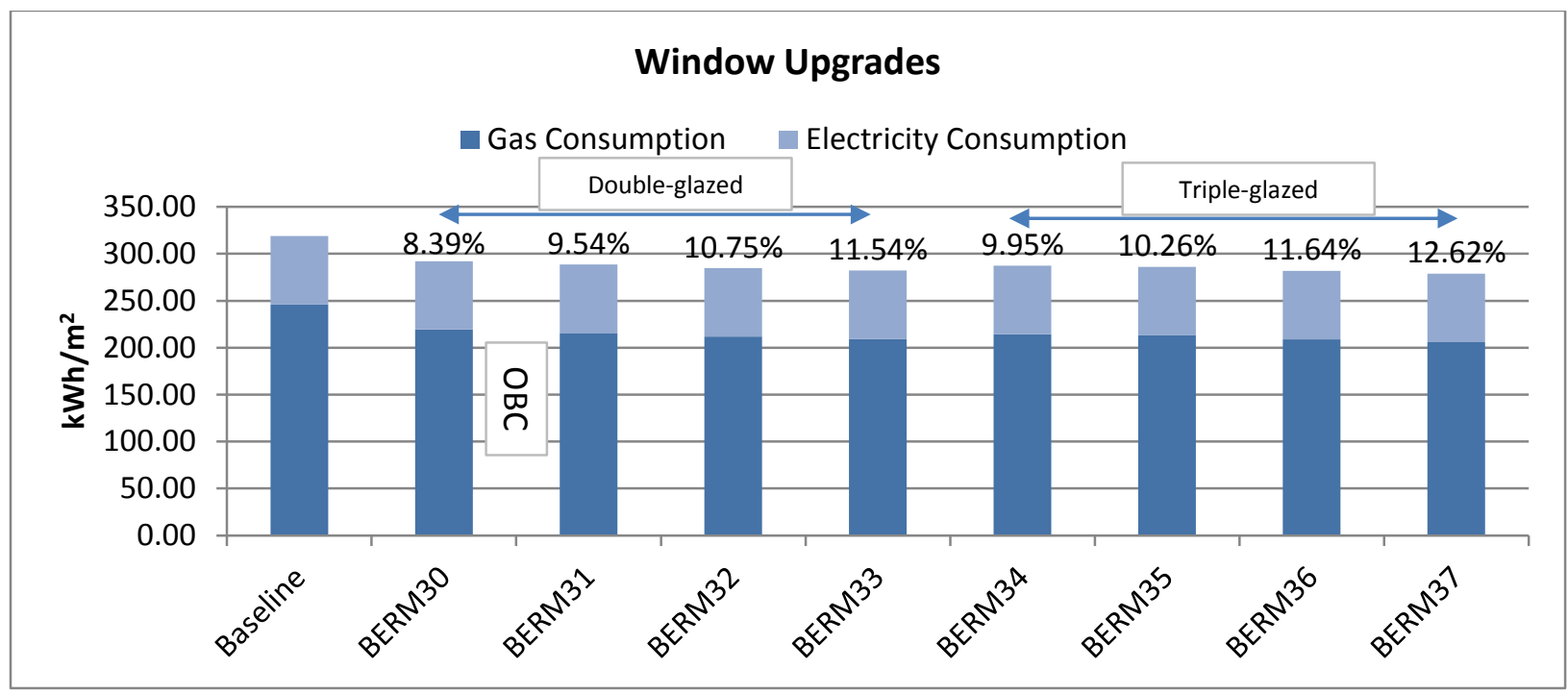

Figure 6-7 Aluminum frame with insulated thermal break window upgrades

Figure 6-8 illustrates the incorporation of the most efficient window frame of the three options introduced in this study. As can be seen from this figure, BERMs 38 to 45 can help to achieve $9 \%$ to $13.22 \%$ energy efficiency. Comparing Figure 6-8 with Figure 6-7, it is clear that insulated fiberglass windows with insulated thermal break will improve the energy efficiency of the building by an average $0.6 \%$.

Table 6-6 RSI Values of window upgrade BERMs with insulated fiberglass frame with insulated thermal break

\begin{tabular}{ccccccccc}
\hline \multirow{2}{*}{ BERMs } & BERM & BERM & BERM & BERM & BERM & BERM & BERM & BERM \\
& 38 & 39 & 40 & 41 & 42 & 43 & 44 & 45 \\
\hline \multirow{2}{*}{$\mathrm{RSI}$} & Double- & Double- & Double- & Double- & Triple- & Triple- & Triple- & Triple- \\
$\left(\mathrm{m}^{2} \mathrm{C} / \mathrm{W}\right)$ & glazed & glazed & glazed & glazed & glazed & glazed & glazed & glazed \\
& 0.36 & 0.44 & 0.55 & 0.65 & 0.46 & 0.48 & 0.56 & 0.83 \\
\hline
\end{tabular}




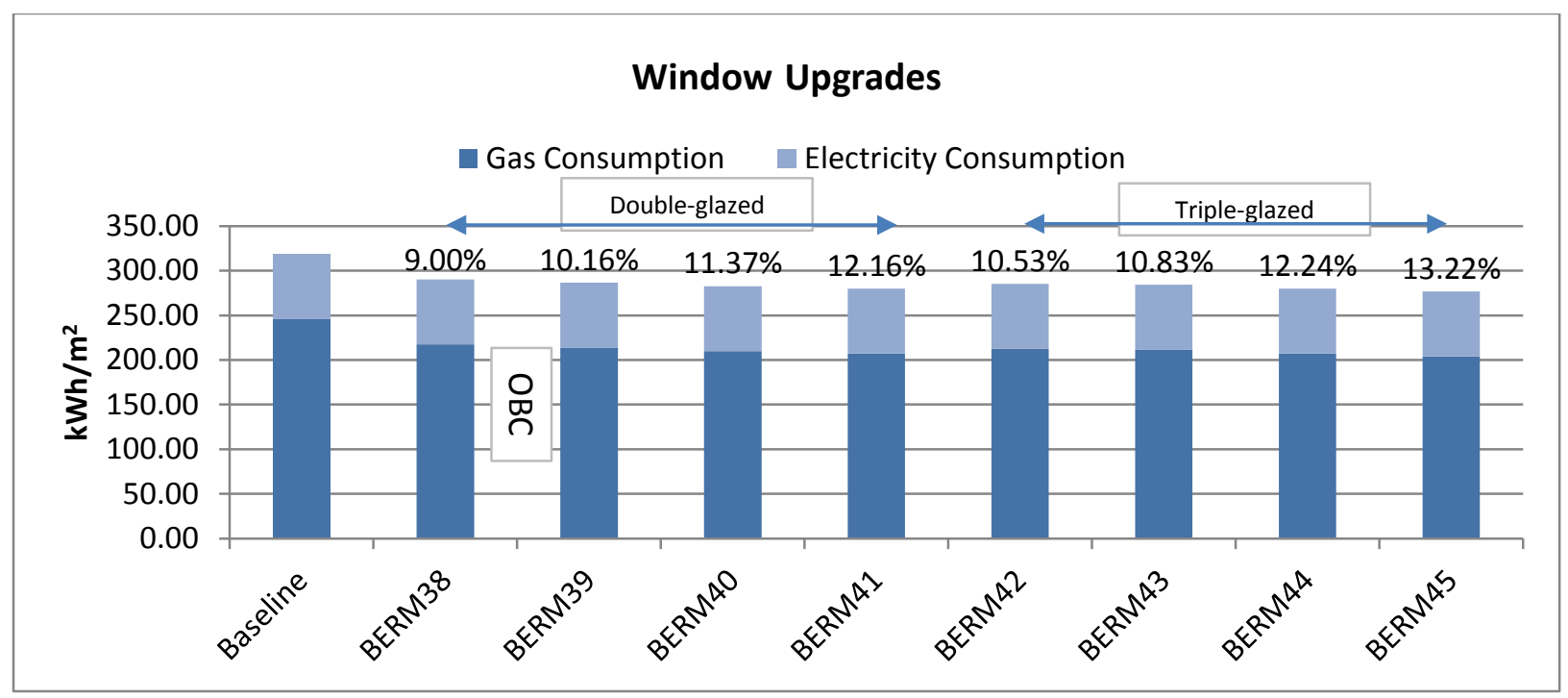

Figure 6-8 Insulated fiberglass frame with insulated thermal break window upgrades

Figure 6-9 below demonstrates the window RSI upgrade curve in all three window frame options. The existing windows of the archetype tower building are amongst the most inefficient options since it's a single-glazed window with aluminum frame; as such, the first upgrade has the most impact on energy consumption of the building. Depending on the option, the first upgrade has the potential to reduce energy consumption of the archetype tower from $7.33 \%$ up to $9 \%$.

Upgrading existing single-glazed with double-glazed window options presented in this study can result in energy conservation of $7.33 \%$ to $12.16 \%$ (considering both the window frames and glass area). Relatively, upgrading the existing single-glazed with triple-glazed windows utilized in this research has an outcome of $8.78 \%$ to $13.22 \%$ savings in building energy use. Therefore, the impact of upgrading single-glazed windows to double-glazed are more prominent than upgrading single-glazed to tripleglazed windows.

These results reveal that the number of glass panes influences energy efficiency more 
than the thermal break, which is more effective than window frame material in reference to energy conservation.

The first inflection point in window upgrades is the first upgrade from single- to doubleglazed in all window frame options. However, this point with an $R S I$ of $0.36\left(\mathrm{~m}^{2} \mathrm{C} / \mathrm{W}\right)$ is below the requirements of OBC 2012 (SB-10). At BERMs 24, 32 and 40, the increase in energy efficiency to the next BERMs starts to drop to below $1 \%$. Consequently, the second inflection points in window upgrades are BERMs 24, 32 and 40 (depending on window frames) with an $\mathrm{RSI}$ value of $0.55\left(\mathrm{~m}^{2} \mathrm{C} / \mathrm{W}\right)$, which is slightly above the requirement of $\mathrm{OBC} 2012$ (SB-10) $\left(0.50 \mathrm{~m}^{2} \mathrm{C} / \mathrm{W}\right)$ for window assembly. These BERMs represent double-glazed window options. It can be concluded that double-glazed windows are the optimal option in a window replacement strategy. If there was a need to increase the impact of window replacement, then triple-glazed window options, insulated thermal break in the frame and more effective window frame material is recommended, respectively (BERMs 22 to 25,30 to 33 and 38 to 41 are the doubleglazed window options with different window frame choices, representing the optimal points). 


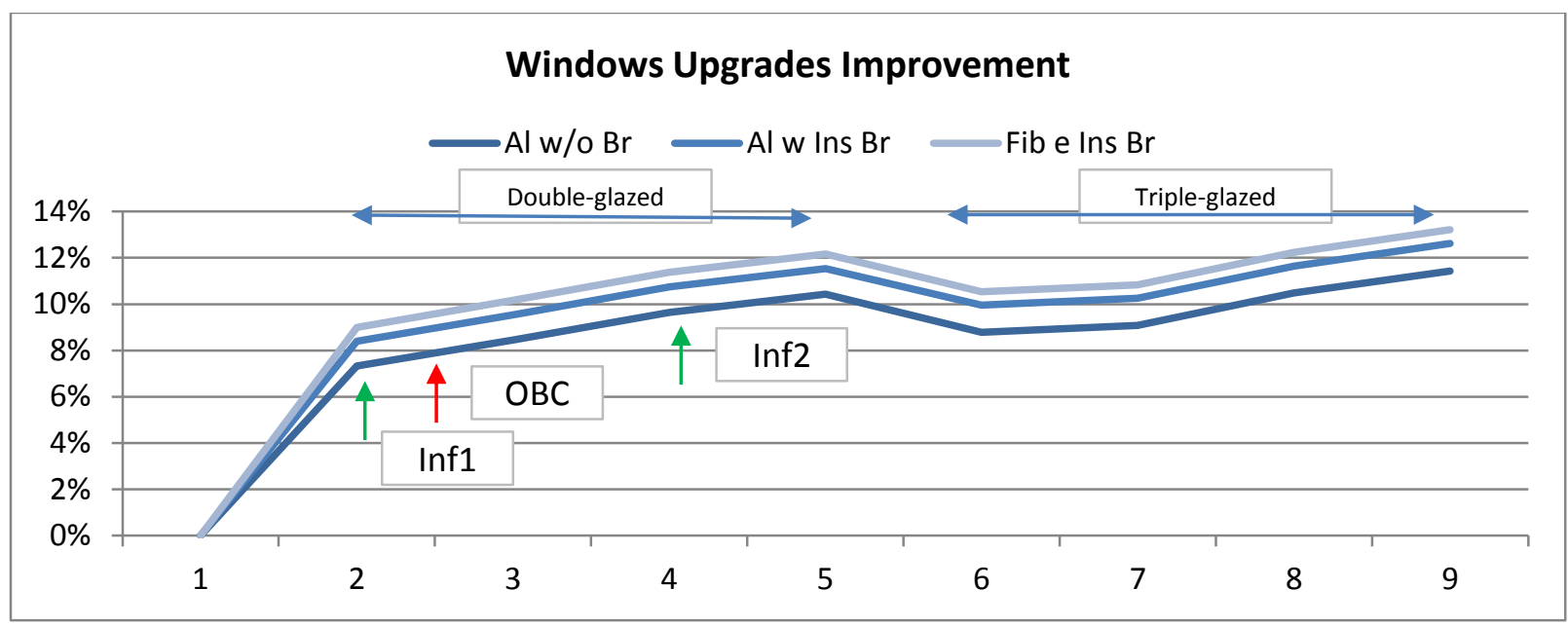

Figure 6-9 Window upgrades curves

\subsubsection{Ground Floor Slab Upgrades}

Similar to other components, the RSI value of ground floor slabs is upgraded from the baseline with an RSI of $0.16\left(\mathrm{~m}^{2} \mathrm{C} / \mathrm{W}\right)$ to an RSI of $0.7,1.41,2.11,2.81,3.5,4.2$ and 4.9 $\left(\mathrm{m}^{2} \mathrm{C} / \mathrm{W}\right)$.

The RSI value of $4.9(\mathrm{~m} 2 \mathrm{C} / \mathrm{W})$ is very hard to achieve due to thickness limitations for the application on the ground floor slab. Since this study evaluates the impact of the values beyond code standards, it has been chosen as the maximum upgrade level. BERM 46 to 52 represents the upgrades to the ground floor slab.

Figure 6-10 illustrates the results of the upgrades and its influence on energy saving. Table 6-7 demonstrates the RSI value with BERMs in the ground floor upgrade strategy.

As can be seen in Figure 6-10, based on the minimum and the maximum values incorporated in this study, an impact range of $1.37 \%$ to $2.19 \%$ on energy efficiency is expected with the application of this strategy. 
Table 6-7 RSI values of ground floor slab upgrade BERMs

\begin{tabular}{cccccccc}
\hline BERMs & BERM 46 & BERM 47 & BERM 48 & BERM 49 & BERM 50 & BERM 51 & BERM 52 \\
\hline $\begin{array}{c}\text { RSI } \\
\left(\mathrm{m}^{2} \mathrm{C} / \mathrm{W}\right)\end{array}$ & 0.7 & 1.41 & 2.11 & 2.81 & 3.5 & 4.2 & 4.9 \\
\hline
\end{tabular}

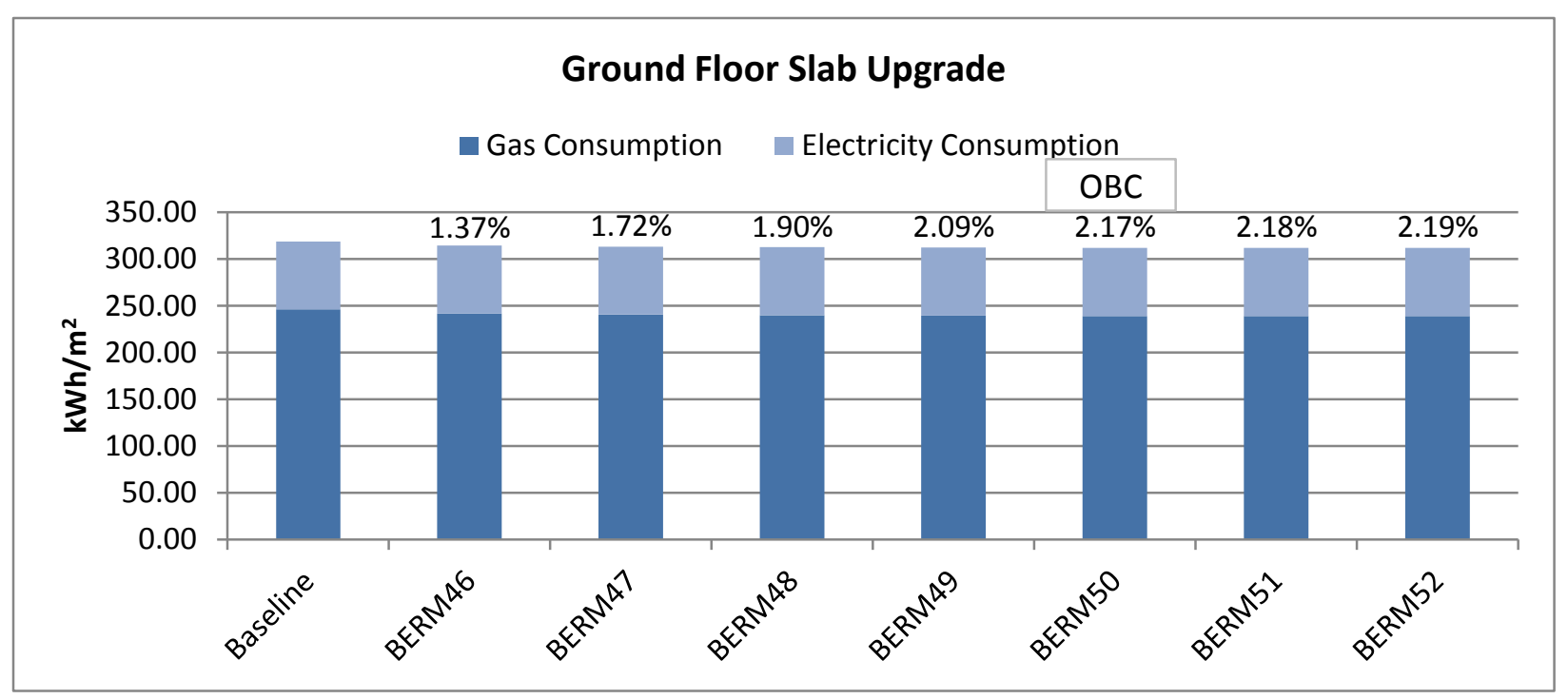

Figure 6-10 Ground floor slab upgrades

Figure 6-11 represents the Ground Floor Slab Upgrade Curve. Similar to other building envelope components, the first inflection point is the first upgrade from no insulation and the RSI value of $0.16\left(\mathrm{~m}^{2} \mathrm{C} / \mathrm{W}\right)$ to a small upgrade of $\mathrm{RSI} 0.7\left(\mathrm{~m}^{2} \mathrm{C} / \mathrm{W}\right)$. This value is much less than the RSI value required by OBC 2012 (SB-10). At BERM 50, the increase in energy efficiency to the next BERMs start to drop to $0.01 \%$ and stay that way for the next upgrade. Consequently, the second inflection point is BERM 50 with an $\mathrm{RSI}$ value of $3.5\left(\mathrm{~m}^{2} \mathrm{C} / \mathrm{W}\right)$, which is exactly the required value by OBC 2012 (SB-10). All the RSI values up to $3.5\left(\mathrm{~m}^{2} \mathrm{C} / \mathrm{W}\right)$ represent energy-efficient options for the ground floor slab upgrades, which are practical to achieve. 


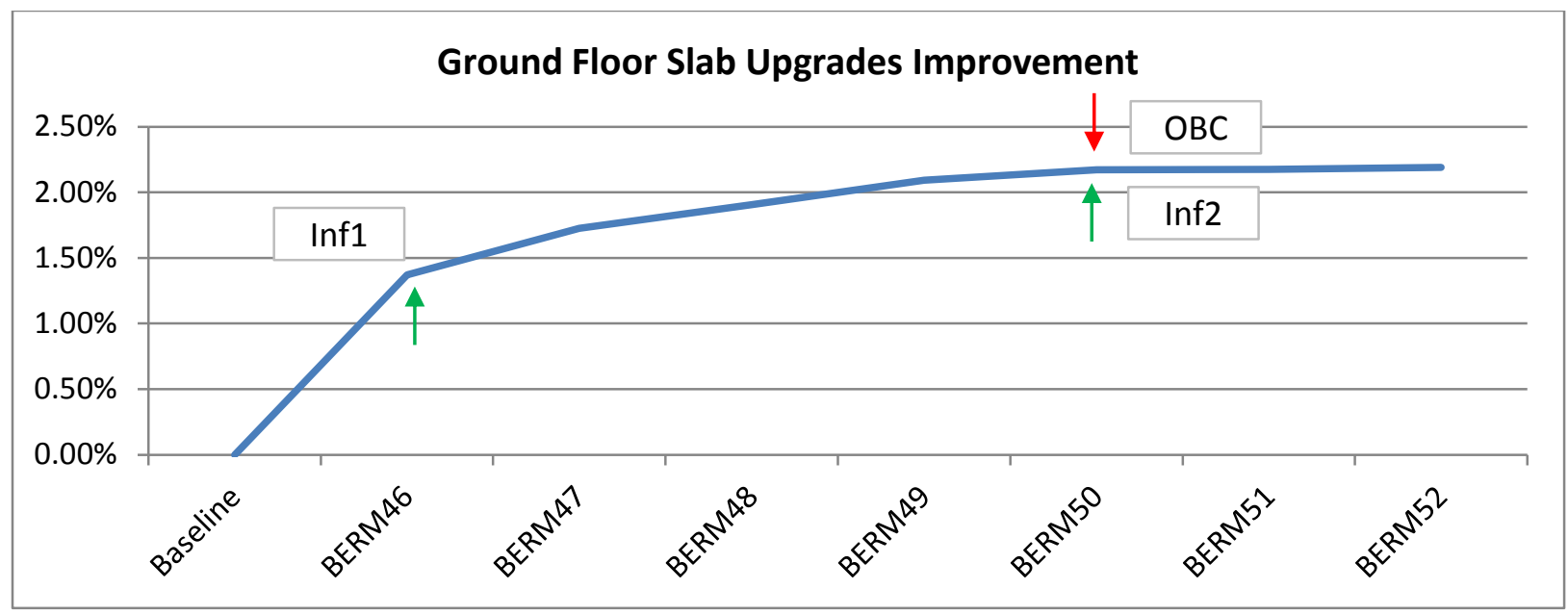

Figure 6-11 Ground floor slab upgrades curve

\subsection{Airtightness Improvement}

It is a fact that building envelope retrofits improve the airtightness of a building via overcladding and window replacement. Careful detailing and execution effort plays a major role on how airtight an envelope is. The actual improvement in airtightness is only identifiable via on-site tests, before and after the building envelope retrofit is applied. Ontario Building Code 2012 (SB-10) does not state any requirement for the airtightness of the entire building envelope but deals with the requirements that apply to individual components.

Since the actual airtightness improvement measures are unknown, the airtightness of the building was improved gradually from the baseline value up to a relatively tight envelope in order to evaluate the impact of airtightness on energy consumption of the building.

The original airtightness value of $2.04 \mathrm{l} / \mathrm{s} . \mathrm{m}^{2}$ was improved to $1.53,1.02,0.51,0.255$, 0.127 and $0.06 \mathrm{l} / \mathrm{s} \cdot \mathrm{m}^{2}$. The value of $0.06 \mathrm{l} / \mathrm{s} . \mathrm{m}^{2}$ is very hard to achieve in practice and is 
only used in the evaluation to find the inflection point in airtightness. BERMs 53 to 58 represent the upgrades on the airtightness of the building envelope. Table 6-8 shows the airtightness value associated with each BERM. Figure 6-12 Airtightness upgrade illustrates the baseline energy intensity as well as the difference in energy intensity between the baseline and the airtightness retrofit cases. The percentage values indicate the improvement levels from the baseline.

Based on the minimum and maximum values incorporated in this study, an impact range of $5.32 \%$ to $22.59 \%$ on energy efficiency is expected. Accordingly, airtightness upgrades have a wide impact range and depending on how well the airtightness of the building envelope is addressed with careful design, detailing and construction, its impact on energy efficiency could be either minimal or significant.

Table 6-8 Airtightness upgrade BERMs

\begin{tabular}{ccccccc}
\hline RCMs & BERM53 & BERM54 & BERM55 & BERM56 & BERM57 & BERM58 \\
\hline $\begin{array}{c}\text { Airtightness } \\
\text { l/s.m }{ }^{2}\end{array}$ & 1.53 & 1.02 & 0.51 & 0.255 & 0.127 & 0.06 \\
\hline
\end{tabular}

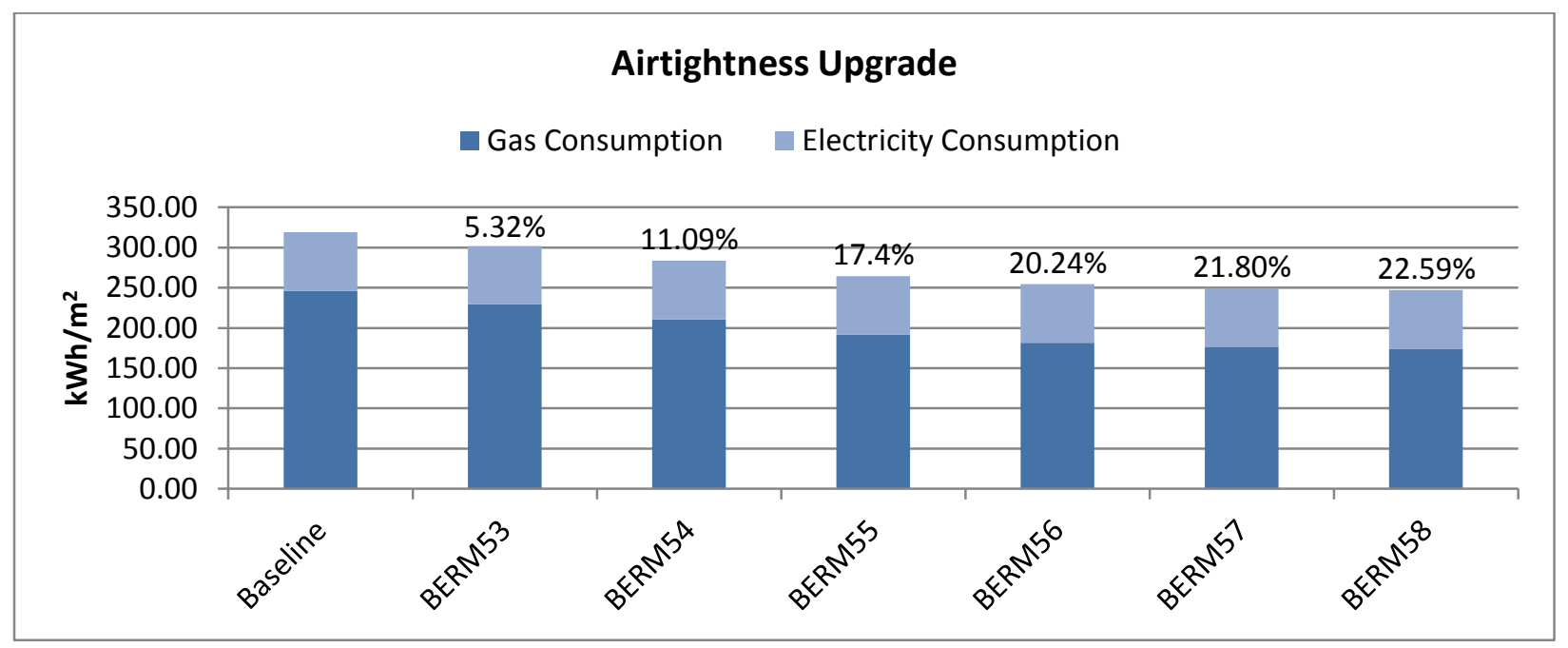

Figure 6-12 Airtightness upgrade 
Figure 6-13 represents the airtightness upgrades curve. Unlike building envelope components, the first inflection point is not the first upgrade from the baseline. The first inflection point is BERM 56 with an airtightness value of $0.255 \mathrm{l} / \mathrm{s} . \mathrm{m}^{2}$, which represents an airtight envelope (Hanam, Finch, \& Hepting, N/A). The improvement from one BERM to the next is above $3 \%$ up to BERM 56 , while the upgrade from BERM 56 to 58 drops to $1.5 \%$.

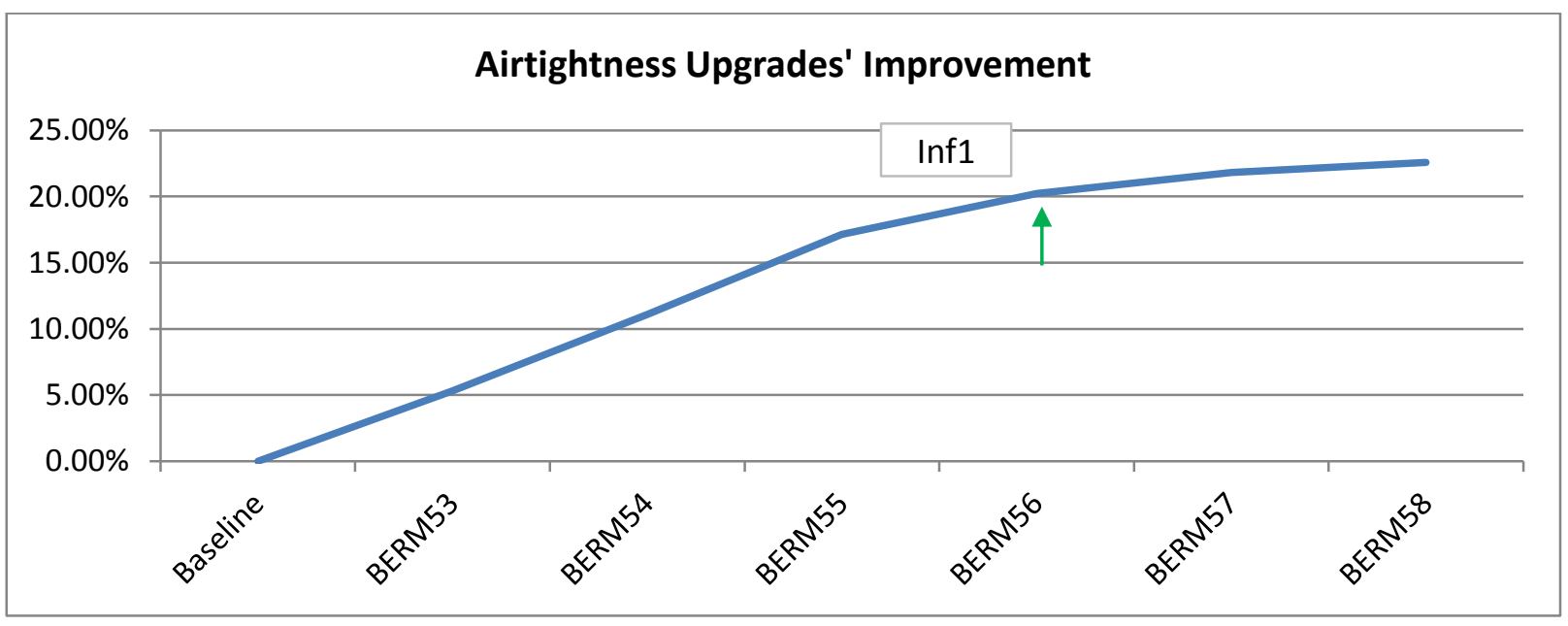

Figure 6-13 Airtightness upgrades curve

Improving the airtightness in a building has many benefits including reducing the heating demand and associated cost, building envelope durability, occupants' health and comfort, and performance upgrade of the HVAC system. Generally, air leakage highly impacts the building's heating and cooling demand.

\subsection{Combined Comprehensive Building Envelope Retrofit and Airtightness Upgrades}

This section evaluates the impact of building envelope upgrades based on optimal RSI and airtightness values. A comprehensive building envelope retrofit based on inflection point 1 and 2 RSI values has been simulated on the eQUEST model and the results are 
compared with comprehensive retrofits based on OBC 2012 (SB-10). The airtightness value for all three models was considered the optimal value found in section 6.3. BERM 59 represents the comprehensive building envelope retrofit based on inflection point 1 . BERM 60 reflects on inflection point $2 \mathrm{RSI}$ values and BERM 61 denotes a comprehensive building envelope retrofit based on OBC 2012 (SB-10). Table 6-9 below summarizes the RSI values of each component for the BERMs.

Table 6-9 Details of BERM 61 to 63

\begin{tabular}{cccccc}
\hline BERMs & Roof RSI & $\begin{array}{c}\text { Exterior Wall } \\
\text { and balcony } \\
\text { slab RSI }\end{array}$ & Window RSI & $\begin{array}{c}\text { Ground } \\
\text { Floor Slab } \\
\text { RSI }\end{array}$ & $\begin{array}{c}\text { Airtightness } \\
\text { RSI }\end{array}$ \\
\hline $\begin{array}{c}\text { BERM 59 } \\
\text { Inflection 1 } \\
\text { BERM 60 } \\
\text { Inflection 2 } \\
\text { BERM 61 }\end{array}$ & $2.11 \mathrm{~m}^{2} \mathrm{C} / \mathrm{W}$ & $1.4 \mathrm{~m}^{2} \mathrm{C} / \mathrm{W}$ & $0.35 \mathrm{~m}^{2} \mathrm{C} / \mathrm{W}$ & $0.7 \mathrm{~m}^{2} \mathrm{C} / \mathrm{W}$ & $0.255 \mathrm{l} / \mathrm{s} . \mathrm{m}^{2}$ \\
$\begin{array}{c}\text { OBC 2012 } \\
(\mathrm{SB}-10)\end{array}$ & $5.28 \mathrm{~m}^{2} \mathrm{C} / \mathrm{W}$ & $3.17 \mathrm{~m}^{2} \mathrm{C} / \mathrm{W}$ & $0.55 \mathrm{~m}^{2} \mathrm{C} / \mathrm{W}$ & $3.5 \mathrm{~m}^{2} \mathrm{C} / \mathrm{W}$ & $0.255 \mathrm{l} / \mathrm{s} . \mathrm{m}^{2}$ \\
\hline
\end{tabular}

Figure 6-14 below illustrates the impact of BERMs 59 to 60 on energy consumption of the archetype tower. As can be seen from the image below, a comprehensive building envelope retrofit based on inflection point 1 reduces energy consumption of the building by $56.8 \%$. The impact of BERM 60 can also result in a reduction of $60.3 \%$. At last, a retrofit based on OBC 2012 (SB-10) along with airtightness upgrade results in savings of $60.6 \%$ in energy consumption of the archetype tower.

These results show that based on the optimal range between inflection points 1 and 2 , savings of $56.8 \%$ to $60.3 \%$ is achievable.

Comparing these results with BERM 61 reveals that the savings from inflection point 1 
RSI values are lower than the OBC 2012 (SB-10); however, savings achieved from inflection point 2 RSI values are closer to code standards.

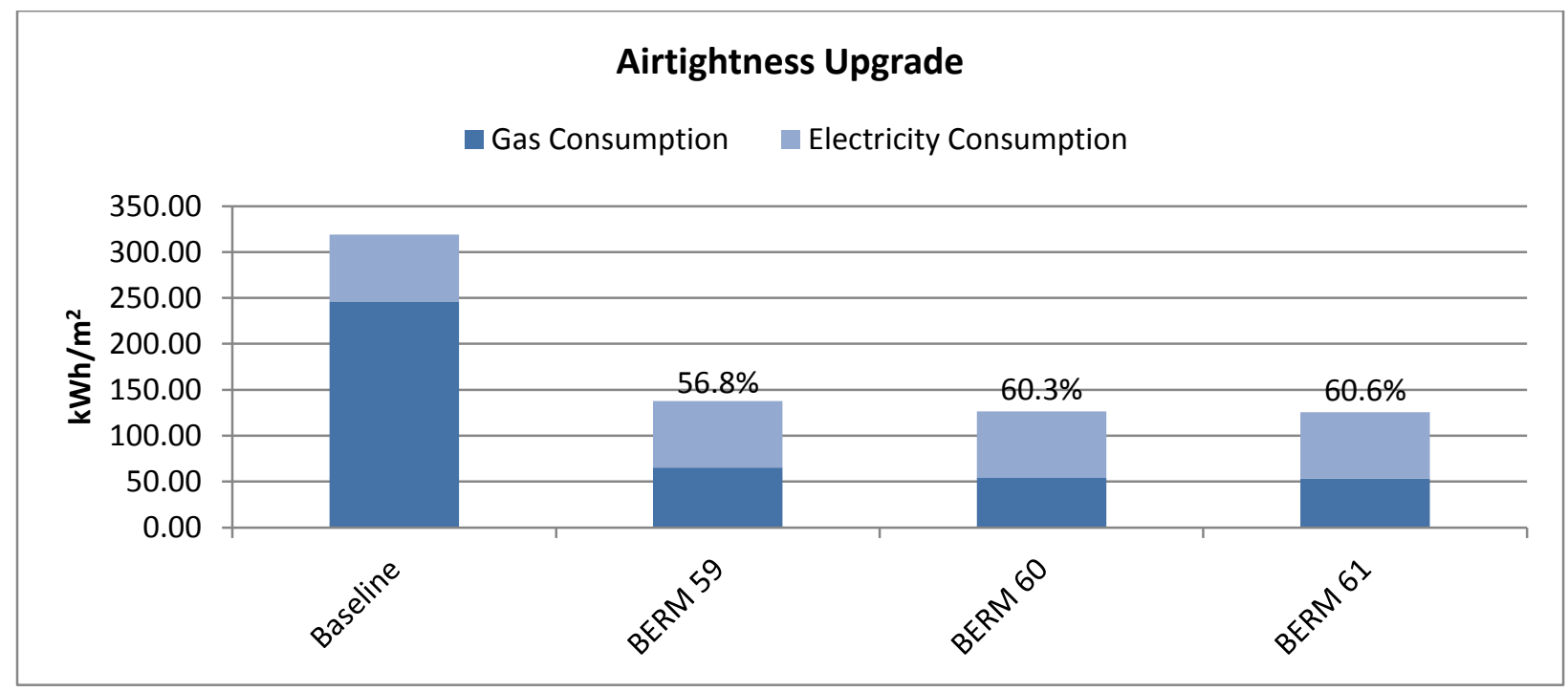

Figure 6-14 Impact of comprehensive building envelope retrofit and airtightness upgrade on energy consumption of the archetype tower 


\section{Comparison of Building Envelope Retrofit Strategies}

Upgrading the RSI value of each assembly, it was observed that the first upgrade has the most impact on energy conservation. This is due to the lack of insulation in the opaque parts of the building envelope and the most inefficient window type that was incorporated in the existing building. Since the upgrade measures for the first upgrades are below the requirements of OBC 2012(SB-10), the second inflection points were also found on the upgrade curves for each assembly. The increase in RSI values also revealed that after inflection point 2, the energy-saving enhancement is negligible. Hence, the optimal RSI values for the upgrade of each component were found to be between inflection points 1 and 2 .

Since achieving the OBC 2012 (SB-10) RSI values are practiced more commonly in the industry, obtaining RSI values up to code and standards are conventional and cost effective. In the case of building envelope retrofits, it was realized that the optimal points are equal or less than OBC 2012 (SB-10) values, which also makes them cost effective.

However, the airtightness upgrade is the only strategy in which the first upgrade is not its inflection point. In airtightness upgrades, the value that represents a relatively tight envelope is where the inflection point is located.

Figure 7-1 below shows the upgrades' curves of building envelope components and airtightness. The range of impact of each component and the first inflection points are also shown in the figure below. It should be noted that the impact range of each component or airtightness could possibly upsurge if the RSI or airtightness values are improved, but the rise in energy efficiency will be insignificant. 
As can be seen, roof insulation has the least impact amongst the building envelope retrofit strategies with an impact range of $0.7 \%$ to $0.85 \%$. Ground floor insulation has the second least impact on energy savings, which ranges from approximately $1.4 \%$ to $2.2 \%$. Window upgrades are in the middle with an impact range of $7.3 \%$ to $13.2 \%$. Exterior wall and balcony over-cladding is the most effective option with an impact range of approximately $24 \%$ to $30.5 \%$. Airtightness upgrade is also the second most effective strategy with the widest impact range of $5.33 \%$ to $22.6 \%$. The airtightness is a co-benefit of application of other building envelope strategies.

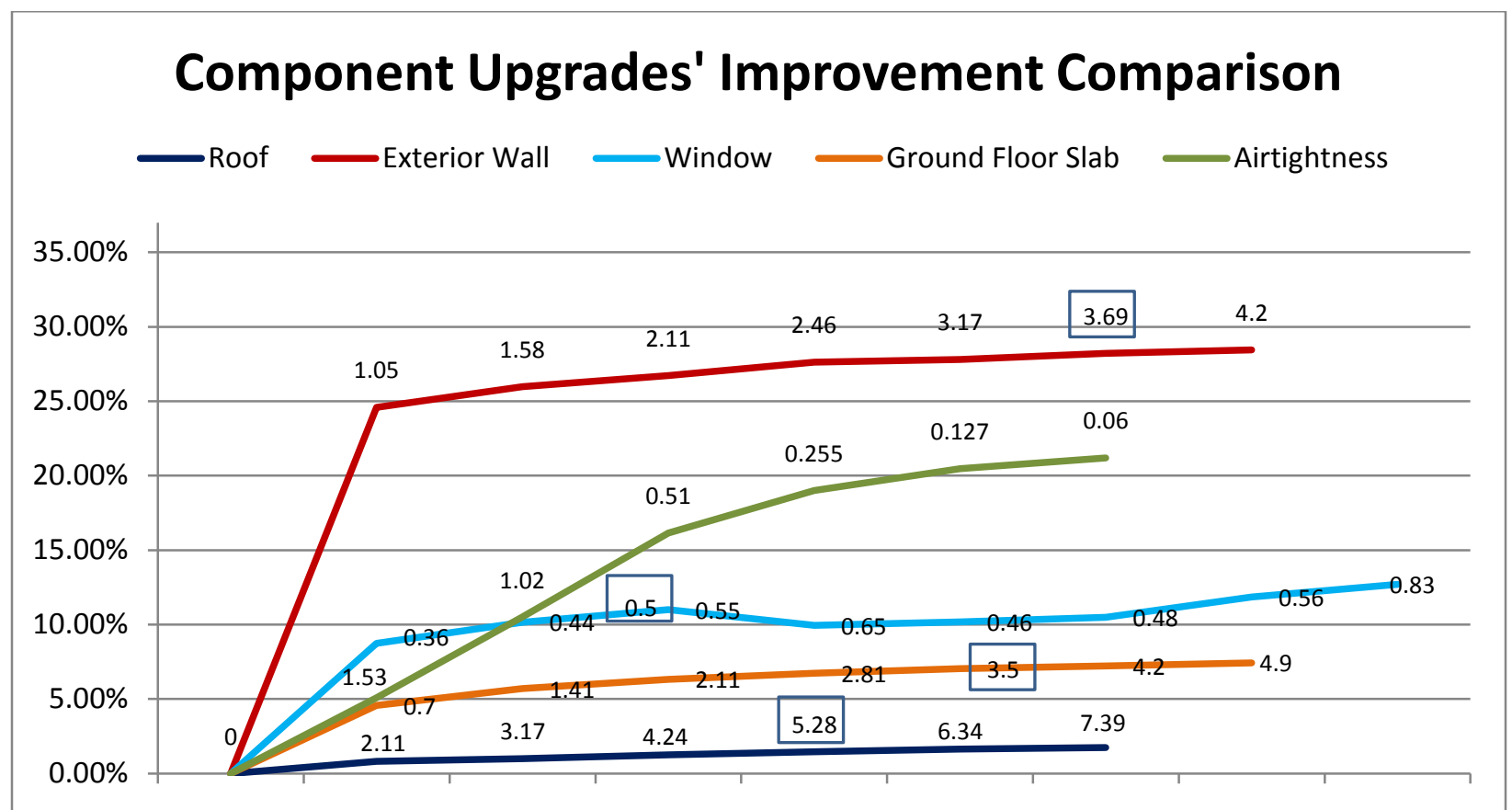

Figure 7-1 Components upgrades' improvement comparison (horizontal axis represents the upgrade in RSI values and airtightness which has been shown in the figure above. The OBC RSI value are outlined on figure above) 


\section{Ranking Building Envelope Retrofit Strategies Based on Energy Efficiency, Initial Capital Cost and Payback Period}

Before the implementation of building envelope retrofit strategies on a postwar tower, it is important to optimize the RSI value of the insulation or the windows by forecasting the energy savings over the life of the building. From previous sections, it was concluded that building envelope retrofit strategies from the highest to the lowest impact on energy consumption are exterior wall and balcony over-cladding, window replacement, ground floor insulation, and roof insulation, respectively.

Airtightness is considered a co-benefit of building envelope retrofit and thus is not considered as a separate strategy. It should be noted that airtightness is a factor that relies on careful detailing and execution effort of the wall assembly and window replacement and therefore building envelope retrofit strategies must consider these factors to be able to achieve an airtight envelope.

In addition to energy-efficiency analysis, it is very important for a retrofit strategy to also be cost effective. As discussed in section 2.7, Kesik and Saleff's report presents a detailed analysis on the building envelope retrofit cost of the archetype tower selected for this research, revealing the initial capital cost and payback time of different strategies.

These results show that over-cladding walls and balconies are the most expensive projects and have the longest payback period, followed by window replacement with the highest initial cost and payback time. Additionally, roof insulation is the most inexpensive option with the shortest payback period (Kesik \& Saleff, 2009). 
It is important to keep in mind that this study does not evaluate the impact of ground floor insulation. However, it's a fair assumption to consider that the cost associated with roof and ground floor insulation are very similar since they both have identical square meters of area if the same insulation material is applied to both assemblies. The cost of insulating the ground floor could also be less since the roof retrofit requires more protective layers to be installed. If the cost of insulating both assemblies are considered the same (or even if the cost of ground floor insulation is less than roof insulation), ground floor slab insulation will have a shorter payback period because its energysaving factor and energy cost saving is higher than the roof insulation strategy (based on the energy modelling results of this study).

This study attempts to rank the 4 building envelope retrofit strategies (roof, exterior wall and slab/balconies edges, windows, and ground floor slab) based on their energyefficiency measure, initial capital cost, and payback time.

This ranking identifies the most effective or optimal strategy to be applied on the archetype postwar MURB. The ranking systems of these three categories are as follows:

Energy saving (it should be noted that the strategies consider the whole range of savings as a result of all BERMs):

- $0 \%-5 \%$ energy saving $=1$

- $5 \%-10 \%$ energy saving $=2$

- $10 \%-15 \%$ energy saving $=3$

- $15 \%-20 \%$ energy saving $=4$ 
- $20 \%-25 \%$ energy saving $=5$

- $25 \%-20 \%$ energy saving $=6$

Payback Period (Based on the results of Kesik and Saleff's study as illustrated in Table 2-5):

- $0-10$ years $=3$

- $10-20$ years $=2$

- $20-30$ years $=1$

Capital Cost

- Most expensive $=1$

- Medium (to high) expensive $=2$

- Medium (to low) expensive $=3$

- Least expensive $=4$

The result of this ranking system is summarized in Table 8-1 below:

Table 8-1 Building envelope strategy ranking

\begin{tabular}{ccccc}
\hline Retrofit Strategy & $\begin{array}{c}\text { Energy-Saving } \\
\text { Measure }\end{array}$ & $\begin{array}{c}\text { Payback } \\
\text { Period }\end{array}$ & $\begin{array}{c}\text { Initial Capital } \\
\text { Cost }\end{array}$ & Total \\
\hline Roof Insulation & 1 & 2 & 3 & $\mathbf{6}$ \\
Window Replacement & 3 & 2 & 2 & $\mathbf{7}$ \\
Over-cladding walls and & 6 & 1 & 1 & $\mathbf{8}$ \\
balconies & 1 & 3 & 4 & $\mathbf{8}$ \\
\hline Ground Floor Insulation & 1 & & & \\
\hline
\end{tabular}

As can be seen from Table 8-1 above, ground floor insulation and over-cladding walls and slab/balcony edges are the highest rankings. Ground floor insulation is a very costeffective strategy just like roof insulation, but the result of energy-saving analysis shows 
that savings achieved is $1.4 \%$ to $2.2 \%$. Over-cladding walls and slab/balcony edges has the highest impact on energy savings, which is $24 \%$ to $30.5 \%$ even though it has the highest capital cost and the longest payback period. Window replacement is ranked in second place. Window replacement has the second highest impact on energy saving $(7.3 \%-13.2 \%)$, it also has the second highest capital cost and second lowest payback period. In contrast with over-cladding walls and balconies is the roof insulation strategy. The roof insulation strategy has the lowest ranking due to its minimal impact on energy saving $(0.7 \%-0.85 \%)$ and relatively higher payback period.

This ranking system considers all three factors as equally important. If energy-efficiency measures are considered more important, the results will change. Energy conservation also impacts on the reduction of greenhouse gas emissions, reducing the environmental impact of the strategies. If the ranking of energy-efficiency measures are considered to be twice as important as initial capital cost and payback period, the results will be as follows (Table 8-2):

Table 8-2 Building envelope strategy ranking with energy efficiency having priority over other factors

\begin{tabular}{ccccc}
\hline Retrofit Strategy & $\begin{array}{c}\text { Energy Saving } \\
\text { Measure }\end{array}$ & $\begin{array}{c}\text { Payback } \\
\text { Period }\end{array}$ & $\begin{array}{c}\text { Initial Capital } \\
\text { Cost }\end{array}$ & Total \\
\hline Roof Insulation & $1 \times 2$ & 2 & 3 & $\mathbf{7}$ \\
Window Replacement & $3 \times 2$ & 2 & 2 & 10 \\
Over-cladding walls and & $6 \times 2$ & 1 & 1 & $\mathbf{1 4}$ \\
balconies & $1 \times 2$ & 3 & 4 & $\mathbf{9}$ \\
\hline Ground Floor Insulation & $1 \times 2$ & & & \\
\hline
\end{tabular}

Table 8-2 above illustrates the result of the ranking of building envelope retrofit strategies based on energy efficiency, initial capital cost, and payback period with energy efficiency having priority over the other factors. As can be seen from the table 
above, over-cladding walls and balconies has the highest ranking since this strategy has the highest impact on energy conservation. After that, window replacement has the second highest ranking since energy efficiency achieved from this strategy is also relatively high and the cost is moderate and not as high as the over-cladding strategy. Just like the previous ranking system, roof insulation is the least effective due to its minimal impact on energy saving as well as ground floor slab insulation.

Table 8-1 and Table 8-2 are examples of the impact priorities in projects on the results of the rankings. It is evident that the requirements of projects can be different and thus the ranking system must be adjusted based on the priorities of each project to get an accurate result. 


\section{Discussion}

This section explores the contrast between the research results of this study and previous studies done on building envelope retrofits of postwar MURBs. This section focuses on the comparison between the results of building envelope upgrades based on OBC 2012 (SB-10) of this study with those of Kesik and Saleff, Arup Group, and Touchie.

As previously mentioned, this research studies the impact of building envelope retrofit measures on a 1960 archetype postwar tower that was also used in Kesik and Saleff's study. Their study introduces 8 different building envelope RCMs. Comparing the RSI values incorporated in these 8 RCMs with OBC 2012 (SB-10), it became apparent that the RSI values are below the OBC 2012 (SB-10) requirements. The comparison of the RCMs in Kesik and Saleff's study is based on the payback time of the RCMs. However, while the report does include the gas and electricity consumption values after the implementation of retrofit measures on NRCan Screening Tool, the percentage improvement in energy conservation is not calculated. (Kesik \& Saleff, 2009). Based on the gas and electricity consumption values reported in their study, the energy saving was calculated.

Table 9-1 shows the retrofit in each RCM, and Figure 9-1 below shows a comparison between the energy saving results of the NRCan Screening Tool (Kesik and Saleff study) and eQUEST modelling based on OBC 2012 (SB-10) RSI values (this MRP). As can be seen, the results of the two models are very different from each other even though they both have the same baseline $\left(310 \mathrm{ekWh} / \mathrm{m}^{2}\right)$. This is due to the 
incorporation of different software and RSI values. But one factor that these two results have in common is the order of impact of each component on energy savings. Both results show that roof insulation has the least impact and compound retrofits have the most impact on energy savings. The only result that is in contrast with the eQUEST model is the influence of window replacement. NRCan Screening Tool results show that window replacement's impact on energy savings is more than exterior wall overcladding. Overall the results of Kesik and Saleff's study shows higher energy savings than the results of eQUEST model.

Table 9-1 The retrofit in each RCM in Kesik and Saleff's Study

\begin{tabular}{|l|l|l|l|l|l|l|l|l|}
\hline RCMs & RCM1 & RCM2 & RCM3 & RCM4 & RCM5 & RCM6 & RCM7 & RCM8 \\
\hline \multirow{4}{*}{ Retrofit } & \multirow{3}{*}{ Roof } & $\begin{array}{l}\text { Exterior } \\
\text { Wall }\end{array}$ & $\begin{array}{l}\text { Exterior } \\
\text { Wall }\end{array}$ & Windows & $\begin{array}{l}\text { Balcony } \\
\text { Enclosure }\end{array}$ & $\begin{array}{l}\text { Exterior } \\
\text { Wall } \\
\text { and } \\
\text { Balcony }\end{array}$ & $\begin{array}{l}\text { Exterior } \\
\text { Wall and } \\
\text { Balcony } \\
\text { and } \\
\text { Windows }\end{array}$ & $\begin{array}{l}\text { Exterior } \\
\text { Wall and } \\
\text { Balcony } \\
\text { Enclosure } \\
\text { and } \\
\text { Windows }\end{array}$ \\
\hline
\end{tabular}

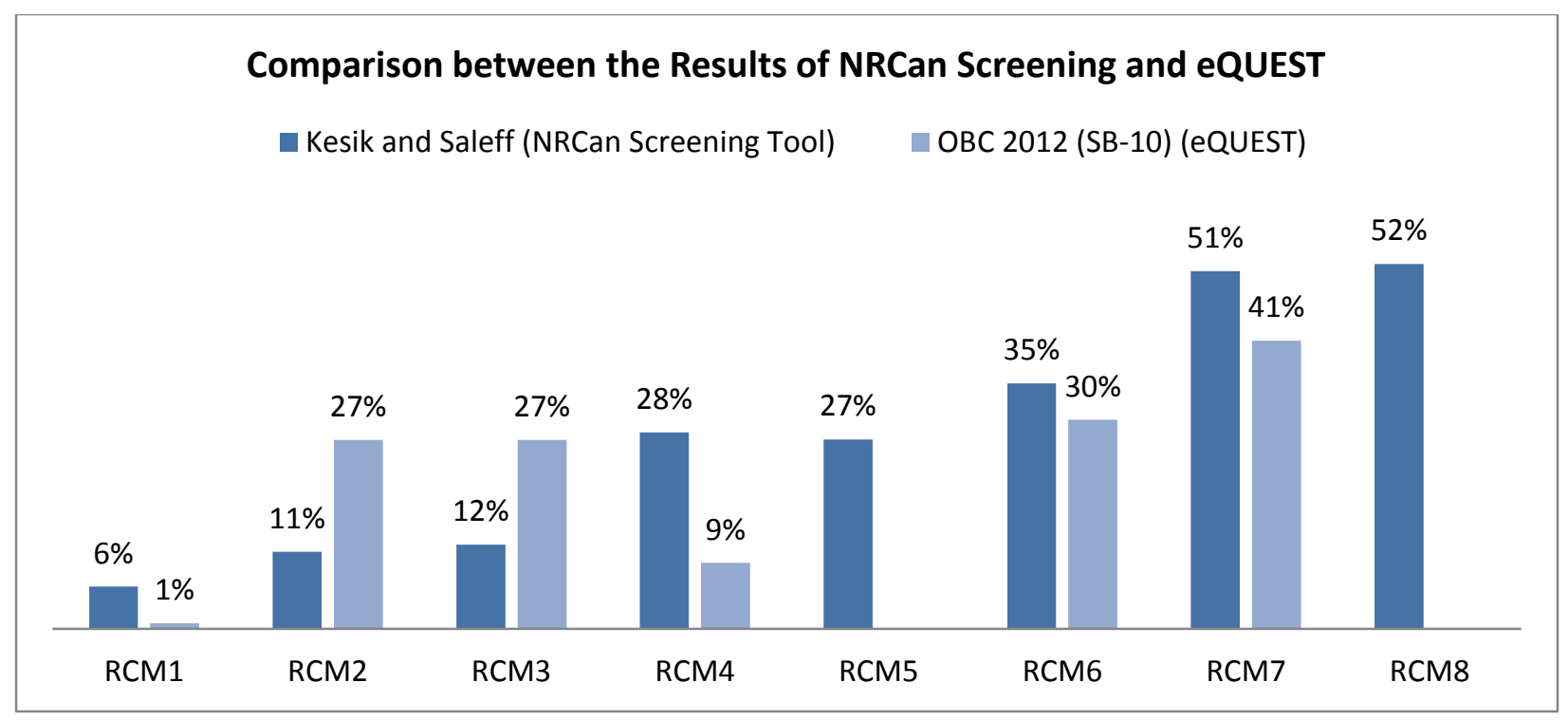

Figure 9-1 Comparison between the energy saving results of NRCan screening (Kesik and Saleff's study) and eQUEST (OBC 2012 (SB-10) RSI values of this MRP) 
The Arup Group study results show that over-cladding has the most impact on energy savings with savings of $36 \%, 30 \%$, and $15 \%$ on 3 different postwar towers. Their study also shows that upgrading single-glazed windows with double glazed can reduce energy consumption by $8 \%, 3 \%$, and $4 \%$ on the same postwar MURBs. These results are approximately in the same margin as the results of this MRP (ARUP Group, 2010).

In Touchie's research, a building built during the 1960s was also studied and the RSI value of all the building envelope components was upgraded, except for the ground floor slab (Touchie, Pressnail, \& Binkley, 2012). Table 9-2 below represents the result of building envelope RCMs on the 1960s building in Touchie's study.

Table 9-2 Touchie's building envelope RCM results (Touchie, Pressnail, \& Binkley, 2012)

\begin{tabular}{|c|c|c|c|c|c|}
\hline Element Retrofit & Base Case & Retrofit 1 & Saving 1 & Retrofit 2 & Saving 2 \\
\hline RCM1- Roof & $0.7\left(\mathrm{~m}^{2} \mathrm{C} / \mathrm{W}\right)$ & $2.11\left(\mathrm{~m}^{2} \mathrm{C} / \mathrm{W}\right)$ & $2.2 \%$ & $2.81\left(\mathrm{~m}^{2} \mathrm{C} / \mathrm{W}\right)$ & $2.8 \%$ \\
\hline $\begin{array}{l}\text { RCM 2- Exterior } \\
\text { Walls }\end{array}$ & $0.7\left(\mathrm{~m}^{2} \mathrm{C} / \mathrm{W}\right)$ & $1.4\left(\mathrm{~m}^{2} \mathrm{C} / \mathrm{W}\right)$ & $5 \%$ & $2.11\left(\mathrm{~m}^{2} \mathrm{C} / \mathrm{W}\right)$ & $7 \%$ \\
\hline RCM 3- Slab Edge & $0.7\left(\mathrm{~m}^{2} \mathrm{C} / \mathrm{W}\right)$ & $1.4\left(\mathrm{~m}^{2} \mathrm{C} / \mathrm{W}\right)$ & $1.3 \%$ & & \\
\hline $\begin{array}{l}\text { RCM 4- } \\
\text { Fenestration }\end{array}$ & Single-glazed & Double-glazed & $6.8 \%$ & Triple-glazed & $7.2 \%$ \\
\hline
\end{tabular}

As can be seen from the table above, the RSI upgrades of the building envelope are much less than the $\mathrm{OBC}$ requirements, which is also reflected on the saving measures. In addition, the existing roof insulation in Touchie's study is less than the existing roof insulation of the archetype tower of this research, but the existing exterior wall and slab edge insulation of Touchie's study building is more than the archetype tower of this research. That's why the impact of roof insulation in Touchie's study is about $2 \%$ to $3 \%$ and the impact of exterior wall over-cladding is about $5 \%$ to $7 \%$. Other factors that cause contrast in the results are building shape, height, and window-to-wall ratio. Overall window replacement and over-cladding are proven to have the highest impact 
on energy efficiency compared to other components (Touchie, Pressnail, \& Binkley, 2012).

Touchie also upgraded the RSI value of each component and analyzed its impact on energy efficiency of the building. It was concluded from her research that the first upgrade has the most impact on energy efficiency. (Touchie, Pressnail, \& Binkley, 2012). However, the additional upgrades were limited to one or two options and the RSI values incorporated were relatively low and even below the requirements of OBC 2012 (SB-10).

Figure 9-2 below summarizes the results of all the studies and compares the percentage savings as a result of upgrades to building envelope components on 1960's buildings in all four studies. It should be noted that all the buildings and the upgrade levels (RSI values) are different.
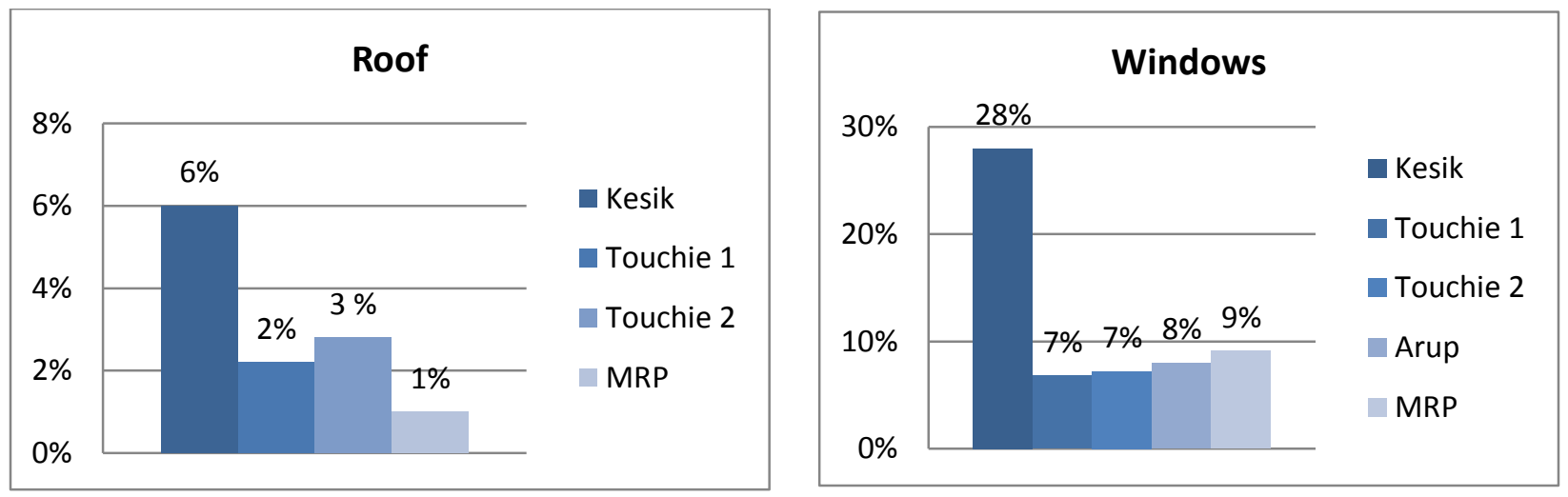

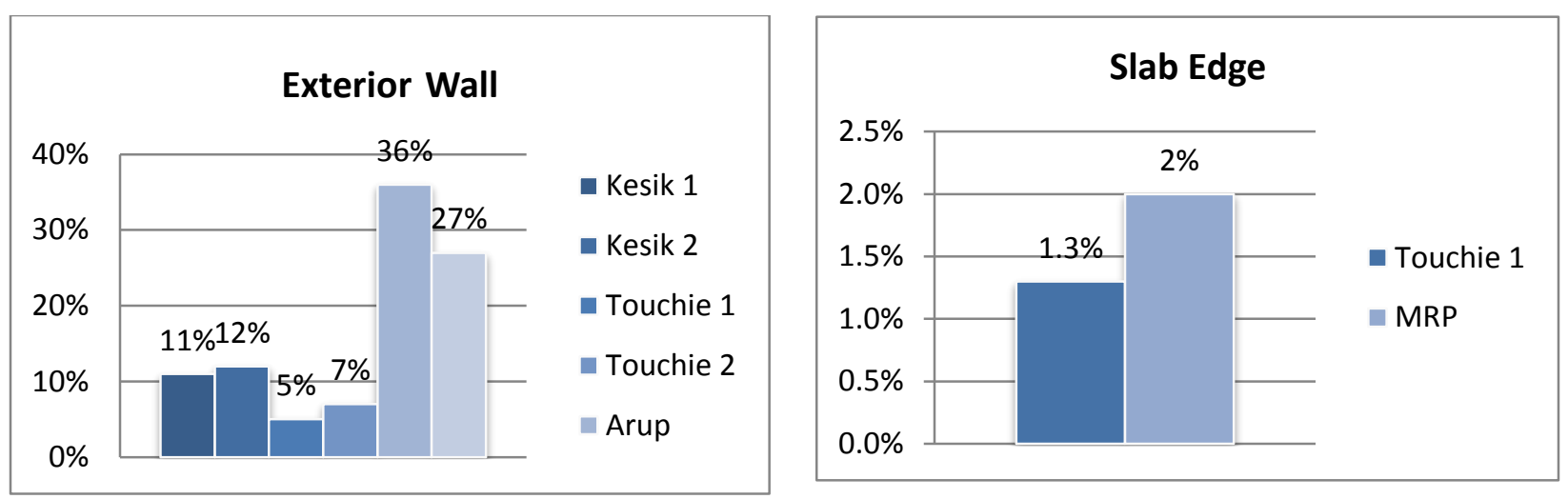

Figure 9-2 Comparison between the results of the studies

Other than the evaluation of the impact of upgrades in RSI value, the influence of airtightness on energy savings is also evaluated in the other studies such as Arup Group and Touchie's.

The Arup Group study results show that re-caulking around the windows to reduce infiltration will result in savings of $5 \%, 8 \%$, and $6 \%$ on 3 different postwar towers (ARUP Group, 2010).

In Touchie's study, the existing airtightness value of the 1960's building was improved from $2.04 \mathrm{l} / \mathrm{s} . \mathrm{m}^{2}$ to $1.53,1.02,0.76,0.51$ and $0.255 \mathrm{l} / \mathrm{s} . \mathrm{m}^{2}$. The resulting energy savings from these upgrades is reported to be $7 \%, 14 \%, 17 \%, 21 \%$, and $24 \%$, respectively. The result of Touchie's study with reference to impact of airtightness on energy consumption of a 1960 postwar building is very close to the result of this study. Figure 9-3 below compares the result of Touchie's study and this MRP for the same airtightness values. 


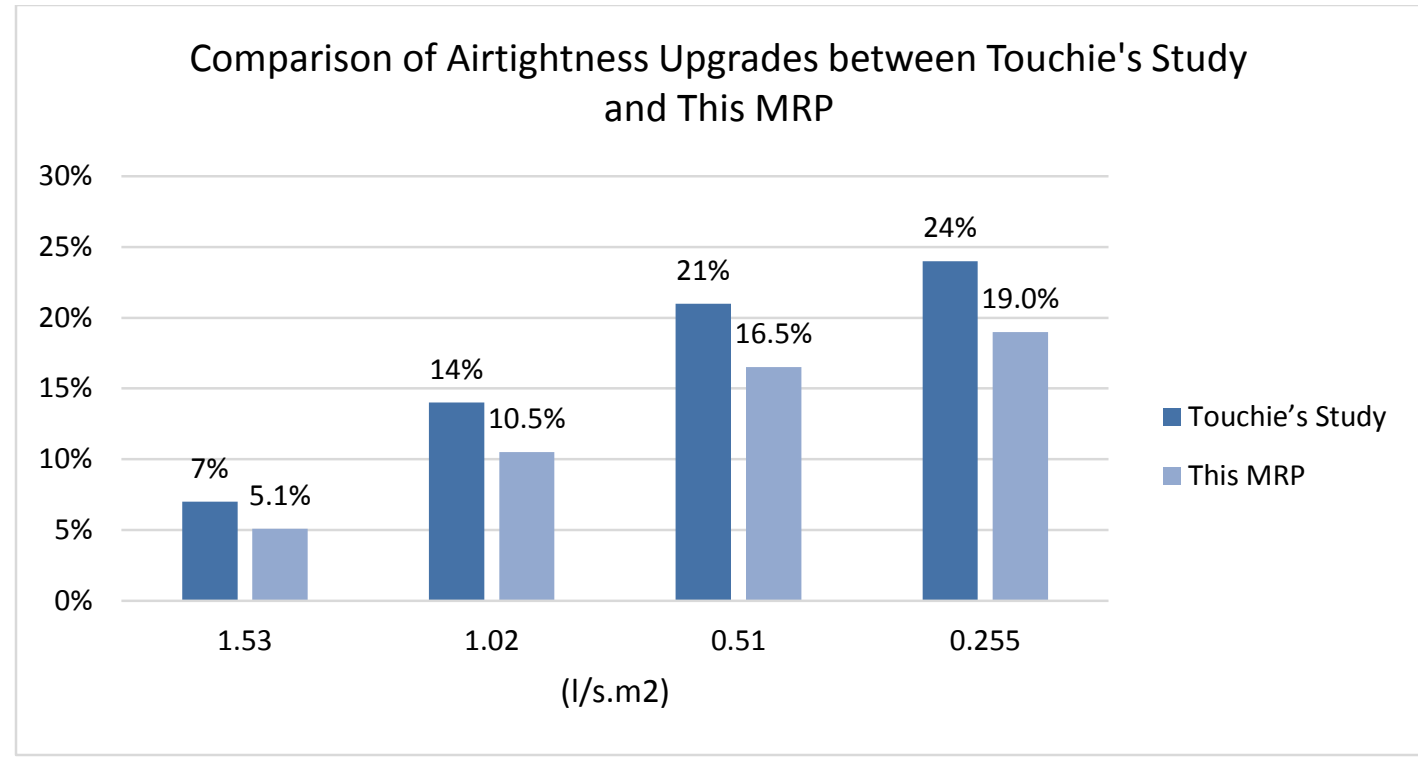

Figure 9-3 Comparison of airtightness upgrades between Touchie's Study and this MRP

All in all, the studies above highlighted the impact of building envelope retrofits on energy consumption of the existing MURB stock. The results show that a building envelope retrofit is an effective option to reduce the energy demands of postwar MURBs. However, the postwar MURBs in the city of Toronto are different from each other and this diversity is evident from the results of studies on different buildings.

Table 9-3 below summarizes all the study results with the existing and improved measures for better comparison.

Table 9-3 Summary of all study results

\begin{tabular}{|c|c|c|c|c|c|}
\hline Study & $\mathrm{RCM}$ & & Existing & Improved & Energy Saving \\
\hline \multirow{9}{*}{$\begin{array}{c}\text { Tower } \\
\text { Renewal } \\
\text { Guideline }\end{array}$} & RCM1 & Roof & 1.4(m2C/W) & $3.5(\mathrm{~m} 2 \mathrm{C} / \mathrm{W})$ & $6 \%$ \\
\hline & RCM2 & Exterior Wall & $0.6(\mathrm{~m} 2 \mathrm{C} / \mathrm{W})$ & $2.1(\mathrm{~m} 2 \mathrm{C} / \mathrm{W})$ & $11 \%$ \\
\hline & $\mathrm{RCM} 3$ & Exterior Wall & $0.6(\mathrm{~m} 2 \mathrm{C} / \mathrm{W})$ & $2.8(\mathrm{~m} 2 \mathrm{C} / \mathrm{W})$ & $12 \%$ \\
\hline & RCM4 & Window & $0.2(\mathrm{~m} 2 \mathrm{C} / \mathrm{W})$ & $0.44(\mathrm{~m} 2 \mathrm{C} / \mathrm{W})$ & $28 \%$ \\
\hline & \multirow{2}{*}{ RCM5 } & $\begin{array}{c}\text { Balcony } \\
\text { Enclosure }\end{array}$ & $0(\mathrm{~m} 2 \mathrm{C} / \mathrm{W})$ & $0.44(\mathrm{~m} 2 \mathrm{C} / \mathrm{W})$ & \multirow{2}{*}{$27 \%$} \\
\hline & & Guard & $0(\mathrm{~m} 2 \mathrm{C} / \mathrm{W})$ & $2.64(\mathrm{~m} 2 \mathrm{C} / \mathrm{W})$ & \\
\hline & \multirow{2}{*}{ RCM6 } & Exterior Wall & $0.88(\mathrm{~m} 2 \mathrm{C} / \mathrm{W})$ & $2.8(\mathrm{~m} 2 \mathrm{C} / \mathrm{W})$ & \multirow{2}{*}{$35 \%$} \\
\hline & & Balcony & $0.88(\mathrm{~m} 2 \mathrm{C} / \mathrm{W})$ & $1.76(\mathrm{~m} 2 \mathrm{C} / \mathrm{W})$ & \\
\hline & RCM7 & Exterior Wall & $0.88(\mathrm{~m} 2 \mathrm{C} / \mathrm{W})$ & $2.6(\mathrm{~m} 2 \mathrm{C} / \mathrm{W})$ & $51 \%$ \\
\hline
\end{tabular}




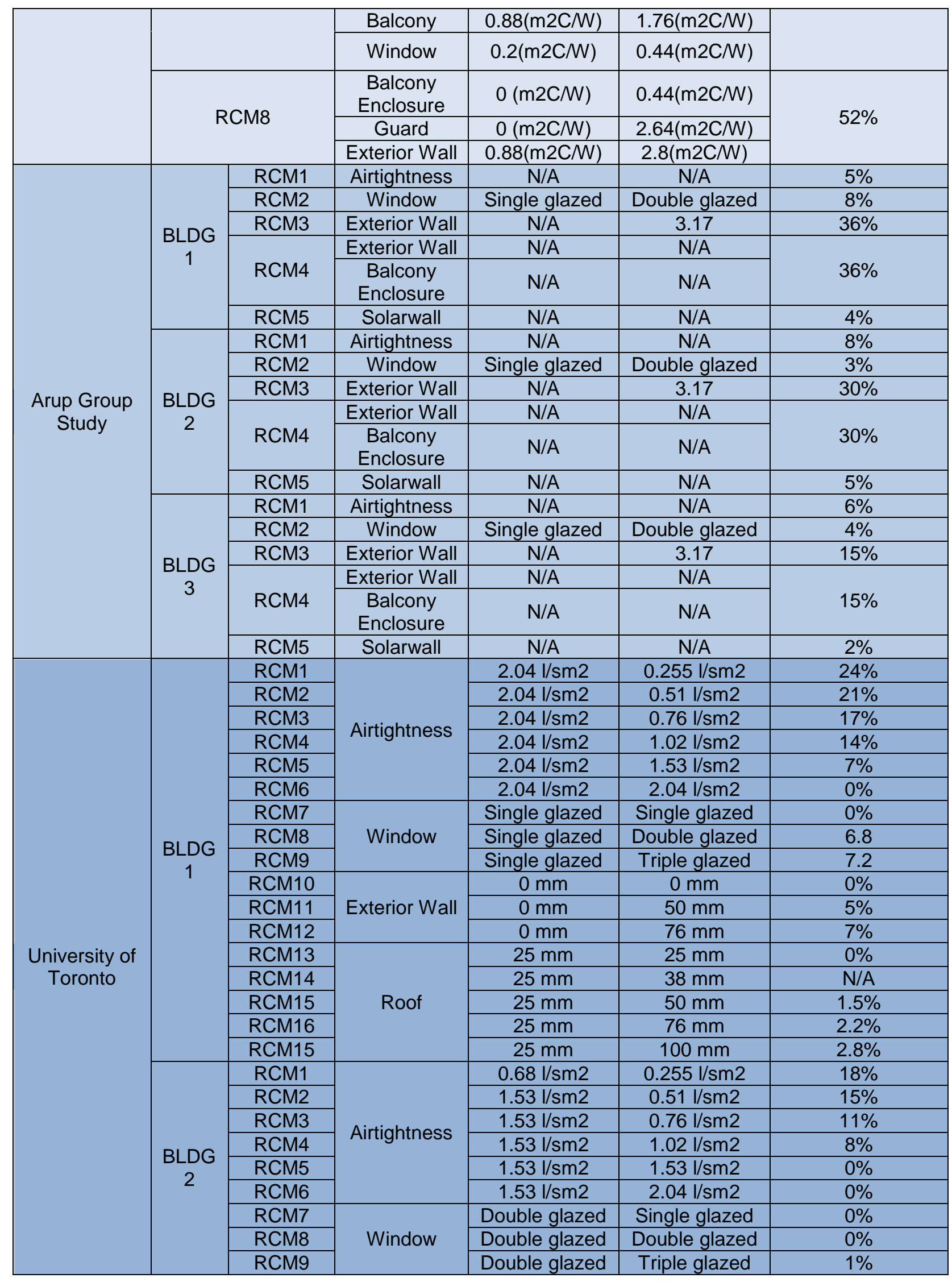




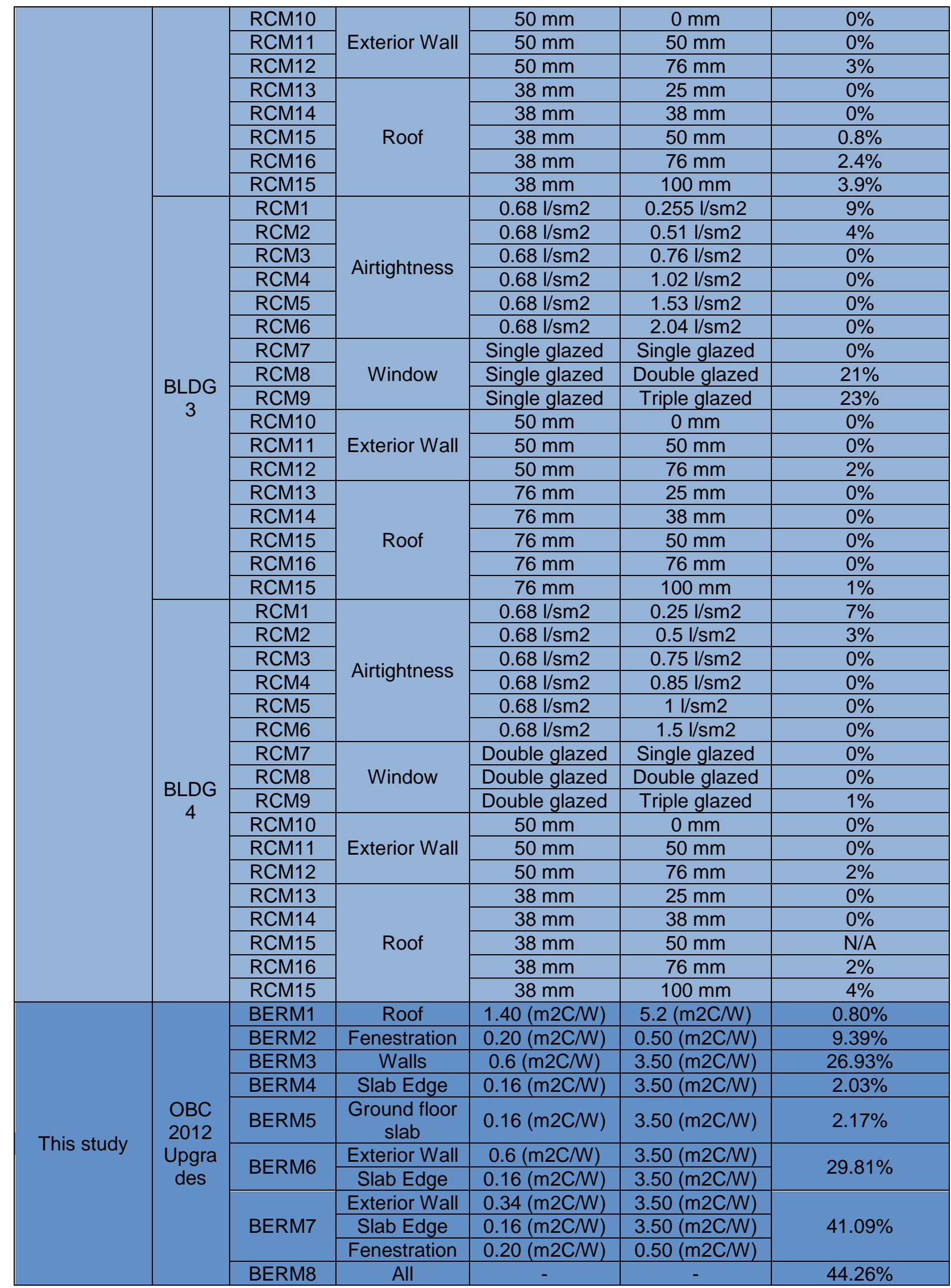




\begin{tabular}{|c|c|c|c|c|c|}
\hline & & Assemblies & & & \\
\hline \multirow{6}{*}{$\begin{array}{l}\text { Roof } \\
\text { Upgra } \\
\text { des }\end{array}$} & BERM9 & Roof & $1.40(\mathrm{~m} 2 \mathrm{C} / \mathrm{W})$ & $2.11(\mathrm{~m} 2 \mathrm{C} / \mathrm{W})$ & $0.69 \%$ \\
\hline & BERM10 & Roof & $1.40(\mathrm{~m} 2 \mathrm{C} / \mathrm{W})$ & $3.17(\mathrm{~m} 2 \mathrm{C} / \mathrm{W})$ & $0.73 \%$ \\
\hline & BERM11 & Roof & $1.40(\mathrm{~m} 2 \mathrm{C} / \mathrm{W})$ & $4.24(\mathrm{~m} 2 \mathrm{C} / \mathrm{W})$ & $0.77 \%$ \\
\hline & BERM12 & Roof & $1.40(\mathrm{~m} 2 \mathrm{C} / \mathrm{W})$ & $5.28(\mathrm{~m} 2 \mathrm{C} / \mathrm{W})$ & $0.80 \%$ \\
\hline & BERM13 & Roof & $1.40(\mathrm{~m} 2 \mathrm{C} / \mathrm{W})$ & $6.34(\mathrm{~m} 2 \mathrm{C} / \mathrm{W})$ & $0.83 \%$ \\
\hline & BERM14 & Roof & $1.40(\mathrm{~m} 2 \mathrm{C} / \mathrm{W})$ & $7.39(\mathrm{~m} 2 \mathrm{C} / \mathrm{W})$ & $0.85 \%$ \\
\hline \multirow{7}{*}{$\begin{array}{c}\text { Ext } \\
\text { Wall + } \\
\text { Blc } \\
\text { Slb } \\
\text { Upgra } \\
\text { de }\end{array}$} & BERM15 & Ext wall+Blc & $0.6(\mathrm{~m} 2 \mathrm{C} / \mathrm{W})$ & $1.40(\mathrm{~m} 2 \mathrm{C} / \mathrm{W})$ & $24.04 \%$ \\
\hline & BERM16 & Ext wall+Blc & $0.6(\mathrm{~m} 2 \mathrm{C} / \mathrm{W})$ & $1.93(\mathrm{~m} 2 \mathrm{C} / \mathrm{W})$ & $26.47 \%$ \\
\hline & BERM17 & Ext wall+Blc & $0.6(\mathrm{~m} 2 \mathrm{C} / \mathrm{W})$ & $2.46(\mathrm{~m} 2 \mathrm{C} / \mathrm{W})$ & $27.86 \%$ \\
\hline & BERM18 & Ext wall+Blc & $0.6(\mathrm{~m} 2 \mathrm{C} / \mathrm{W})$ & $3.17(\mathrm{~m} 2 \mathrm{C} / \mathrm{W})$ & $28.40 \%$ \\
\hline & BERM19 & Ext wall+Blc & $0.6(\mathrm{~m} 2 \mathrm{C} / \mathrm{W})$ & $3.52(\mathrm{~m} 2 \mathrm{C} / \mathrm{W})$ & $29.42 \%$ \\
\hline & BERM20 & Ext wall+Blc & $0.6(\mathrm{~m} 2 \mathrm{C} / \mathrm{W})$ & $3.87(\mathrm{~m} 2 \mathrm{C} / \mathrm{W})$ & $29.81 \%$ \\
\hline & BERM21 & Ext wall+Blc & $0.6(\mathrm{~m} 2 \mathrm{C} / \mathrm{W})$ & $4.40(\mathrm{~m} 2 \mathrm{C} / \mathrm{W})$ & $30.53 \%$ \\
\hline \multirow{8}{*}{$\begin{array}{l}\text { Windo } \\
\text { w } \\
\text { Upgra } \\
\text { de (Al } \\
\text { Fr w/o } \\
\text { br) }\end{array}$} & BERM22 & Window & $0.20(\mathrm{~m} 2 \mathrm{C} / \mathrm{W})$ & $\begin{array}{l}\text { D-g } 0.36 \\
(\mathrm{~m} 2 \mathrm{C} / \mathrm{W})\end{array}$ & $7.33 \%$ \\
\hline & BERM23 & Window & $0.20(\mathrm{~m} 2 \mathrm{C} / \mathrm{W})$ & $\begin{array}{c}\mathrm{D}-\mathrm{g} 0.4 \\
(\mathrm{~m} 2 \mathrm{C} / \mathrm{W})\end{array}$ & $8.45 \%$ \\
\hline & BERM24 & Window & $0.20(\mathrm{~m} 2 \mathrm{C} / \mathrm{W})$ & $\begin{array}{l}\mathrm{D}-\mathrm{g} 0.55 \\
(\mathrm{~m} 2 \mathrm{C} / \mathrm{W})\end{array}$ & $9.64 \%$ \\
\hline & BERM25 & Window & $0.20(\mathrm{~m} 2 \mathrm{C} / \mathrm{W})$ & $\begin{array}{l}\text { D-g } 0.65 \\
(m 2 C / W)\end{array}$ & $10.43 \%$ \\
\hline & BERM26 & Window & $0.20(\mathrm{~m} 2 \mathrm{C} / \mathrm{W})$ & $\begin{array}{l}\text { T-g } 0.46 \\
(\mathrm{~m} 2 \mathrm{C} / \mathrm{W})\end{array}$ & $8.78 \%$ \\
\hline & BERM27 & Window & $0.20(\mathrm{~m} 2 \mathrm{C} / \mathrm{W})$ & $\begin{array}{l}\mathrm{T}-\mathrm{g} 0.48 \\
(\mathrm{~m} 2 \mathrm{C} / \mathrm{W})\end{array}$ & $9.09 \%$ \\
\hline & BERM28 & Window & $0.20(\mathrm{~m} 2 \mathrm{C} / \mathrm{W})$ & $\begin{array}{l}\mathrm{T}-\mathrm{g} 0.56 \\
(\mathrm{~m} 2 \mathrm{C} / \mathrm{W})\end{array}$ & $10.48 \%$ \\
\hline & BERM29 & Window & $0.20(\mathrm{~m} 2 \mathrm{C} / \mathrm{W})$ & $\begin{array}{l}\mathrm{T}-\mathrm{g} 0.83 \\
(\mathrm{~m} 2 \mathrm{C} / \mathrm{W})\end{array}$ & $11.44 \%$ \\
\hline \multirow{8}{*}{$\begin{array}{l}\text { Windo } \\
\text { w } \\
\text { Upgra } \\
\text { de (Al } \\
\text { Fr w } \\
\text { th br) }\end{array}$} & BERM30 & Window & $0.20(\mathrm{~m} 2 \mathrm{C} / \mathrm{W})$ & $\begin{array}{l}\text { D-g } 0.36 \\
(\mathrm{~m} 2 \mathrm{C} / \mathrm{W})\end{array}$ & $8.39 \%$ \\
\hline & BERM31 & Window & $0.20(\mathrm{~m} 2 \mathrm{C} / \mathrm{W})$ & $\begin{array}{c}\text { D-g } 0.4 \\
(\mathrm{~m} 2 \mathrm{C} / \mathrm{W}) \\
\end{array}$ & $9.54 \%$ \\
\hline & BERM32 & Window & $0.20(\mathrm{~m} 2 \mathrm{C} / \mathrm{W})$ & $\begin{array}{l}\text { D-g } 0.55 \\
(\mathrm{~m} 2 \mathrm{C} / \mathrm{W})\end{array}$ & $10.75 \%$ \\
\hline & BERM33 & Window & $0.20(\mathrm{~m} 2 \mathrm{C} / \mathrm{W})$ & $\begin{array}{l}\text { D-g } 0.65 \\
(m 2 C / W)\end{array}$ & $11.54 \%$ \\
\hline & BERM34 & Window & $0.20(\mathrm{~m} 2 \mathrm{C} / \mathrm{W})$ & $\begin{array}{l}\mathrm{T}-\mathrm{g} 0.46 \\
(\mathrm{~m} 2 \mathrm{C} / \mathrm{W})\end{array}$ & $9.95 \%$ \\
\hline & BERM35 & Window & $0.20(\mathrm{~m} 2 \mathrm{C} / \mathrm{W})$ & $\begin{array}{l}\text { T-g } 0.48 \\
(\mathrm{~m} 2 \mathrm{C} / \mathrm{W})\end{array}$ & $10.26 \%$ \\
\hline & BERM36 & Window & $0.20(\mathrm{~m} 2 \mathrm{C} / \mathrm{W})$ & $\begin{array}{l}\mathrm{T}-\mathrm{g} 0.56 \\
(\mathrm{~m} 2 \mathrm{C} / \mathrm{W})\end{array}$ & $11.64 \%$ \\
\hline & BERM37 & Window & $0.20(\mathrm{~m} 2 \mathrm{C} / \mathrm{W})$ & $\begin{array}{l}\text { T-g } 0.83 \\
(\mathrm{~m} 2 \mathrm{C} / \mathrm{W}) \\
\end{array}$ & $12.62 \%$ \\
\hline \multirow{4}{*}{$\begin{array}{l}\text { Windo } \\
\text { w } \\
\text { Upgra } \\
\text { de } \\
\text { (Ins } \\
\text { Fib Fr } \\
\text { w th } \\
\text { br) }\end{array}$} & BERM38 & Window & $0.20(\mathrm{~m} 2 \mathrm{C} / \mathrm{W})$ & $\begin{array}{l}\mathrm{D}-\mathrm{g} 0.36 \\
(\mathrm{~m} 2 \mathrm{C} / \mathrm{W})\end{array}$ & $9.00 \%$ \\
\hline & BERM39 & Window & $0.20(\mathrm{~m} 2 \mathrm{C} / \mathrm{W})$ & $\begin{array}{c}\mathrm{D}-\mathrm{g} 0.4 \\
(\mathrm{~m} 2 \mathrm{C} / \mathrm{W})\end{array}$ & $10.16 \%$ \\
\hline & BERM40 & Window & $0.20(\mathrm{~m} 2 \mathrm{C} / \mathrm{W})$ & $\begin{array}{l}\mathrm{D}-\mathrm{g} 0.55 \\
(\mathrm{~m} 2 \mathrm{C} / \mathrm{W})\end{array}$ & $11.37 \%$ \\
\hline & BERM41 & Window & $0.20(\mathrm{~m} 2 \mathrm{C} / \mathrm{W})$ & $\begin{array}{l}\mathrm{D}-\mathrm{g} 0.65 \\
(\mathrm{~m} 2 \mathrm{C} / \mathrm{W})\end{array}$ & $12.16 \%$ \\
\hline
\end{tabular}




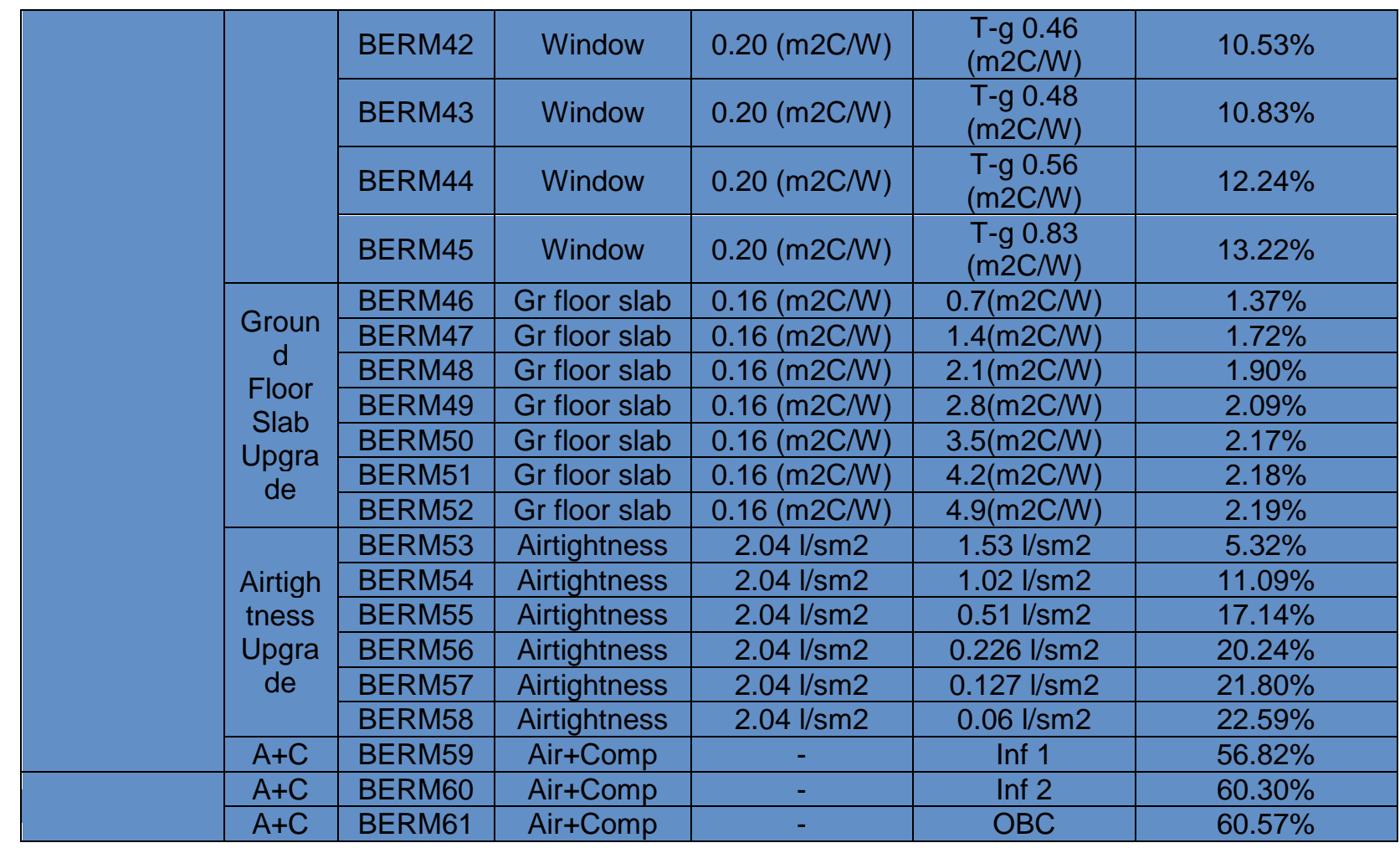




\section{Conclusion}

This section concludes a study in which the impact of building envelope retrofits on energy use of a postwar MURB in Toronto is investigated. The energy consumption analysis is done using energy simulation software called eQUEST.

This study attempts to investigate the energy savings that can be achieved from a building envelope retrofit meeting OBC 2012 (SB-10) requirements. The entire building envelope components are then upgraded individually based on the OBC 2012 (SB-10) standards to evaluate the impact of each component on energy consumption of the building. In addition, the influence of compound building envelope retrofit strategies and comprehensive building envelope retrofits are also evaluated.

The study results reveal that if roof, windows, exterior walls, balconies, slab edges, and ground floor slab of the archetype building are upgraded to meet building codes, the energy savings that can be achieved from each upgrade is $0.8 \%, 9.4 \%, 27 \%, 2 \%$, and $2.2 \%$, respectively. As such, exterior wall over-cladding will result in the most energy savings, followed by a window upgrade strategy. Ground floor and roof insulation are found to have less of an impact on energy efficiency, respectively. It is also evident that compound upgrade strategies (exterior walls and balcony/slab edges, exterior walls and balcony/slab edges and windows, and a comprehensive building envelope retrofit) result in higher energy savings. Comprehensive building envelope retrofit is found to have the highest impact, which is $44.3 \%$ reduction in energy use.

The next step in this MRP evaluates the impact of an incremental increase in the existing RSI value of each component up to a maximum RSI value that is practical to 
achieve. Such evaluation helps to understand the impact of further improvements to building envelope retrofits on energy efficiency and how the upgrades can be optimized.

The study results reveal that roof upgrades have the potential to reduce energy consumption of the archetype building by $0.7 \%-0.85 \%$. The optimal RSI values for such upgrades are those that are equal or less than $4.24\left(\mathrm{~m}^{2} \mathrm{C} / \mathrm{W}\right)$. The exterior wall and slab/balcony edge upgrades can reduce energy use by $24 \%$ to $30.5 \%$, and the optimal $\mathrm{RSI}$ values are those less than or equal to $3.17 \mathrm{~m}^{2} \mathrm{C} / \mathrm{W}$.

Windows upgrade can result in $7.3 \%$ to $13.2 \%$ energy efficiency. Double-glazed windows are found to be the most optimal option for window upgrades compared to triple-glazed windows. Triple glazed windows can increase the energy efficiency by about $1 \%$. The study results also indicates that the insulated thermal break in window frame and the use of a less conductive window frame material (insulated fiberglass window) reduces energy use of the archetype tower by $1 \%$ and $0.6 \%$ respectively.

1.4 to $2.2 \%$ reduction in energy use can result from slab upgrades and the RSI values of less or equal to $3.5\left(\mathrm{~m}^{2} \mathrm{C} / \mathrm{W}\right)$ are found to be the optimal option for this strategy.

With regards to airtightness, the results show that increasing airtightness helps to achieve energy savings of $5.3 \%-22.6 \%$, and the optimal value for this upgrade is 0.255 I/s. $\mathrm{m}^{2}$. (It should be noted that the study results are based on the measures that are incorporated in this study and only applies to the archetype tower that is used for the evaluations.)

The impact of comprehensive building envelope retrofits based on first and second inflection points, and OBC 2012 (SB-10) with optimal airtightness value are also studied 
on archetype tower buildings. The result reveals that comprehensive building envelope retrofits based on inflection points 1 and 2 along with airtightness upgrade, results in savings of $56.8 \%$ to $60.3 \%$ in energy consumption, and comprehensive building envelope retrofits based on OBC 2012 (SB-10) along with airtightness results in saving of $60.6 \%$.

Ranking the retrofit strategies can help the designer in decision making. Since building envelope retrofit is very costly, this study considers initial capital cost and payback period as essential factors in decision making, in addition to energy saving. Ranking the strategies based on these three factors, the best building envelope retrofit strategies are found to be ground floor slab insulation, and over-cladding exterior wall and slabs/balcony edges, followed by window replacement, and at last roof insulation, if all 3 factors are equally important. If energy efficiency has a higher priority than the other two factors, then over-cladding exterior walls and window replacement has the highest ranking, and ground floor slab and roof insulation has the lowest. Generally, the result of the rankings could vary based on the priorities of the projects.

This study highlights the energy performance in the existing MURB stock and the urgent need for building envelope retrofits in the highest-intensity buildings in the city of Toronto. However, postwar MURBs in Toronto are different from each other and this diversity is evident from the results of studies on different buildings, which are highlighted in the discussion section. Any retrofit strategy must recognize the diversity that exists in the postwar MURBs' building stock while encouraging energy retrofits that are critical to reducing energy consumption. This is why the evaluation of retrofit performance is vital before implementation of the strategy. 


\section{Appendices}

\section{1-1 Appendix A: Reference Building Drawings}

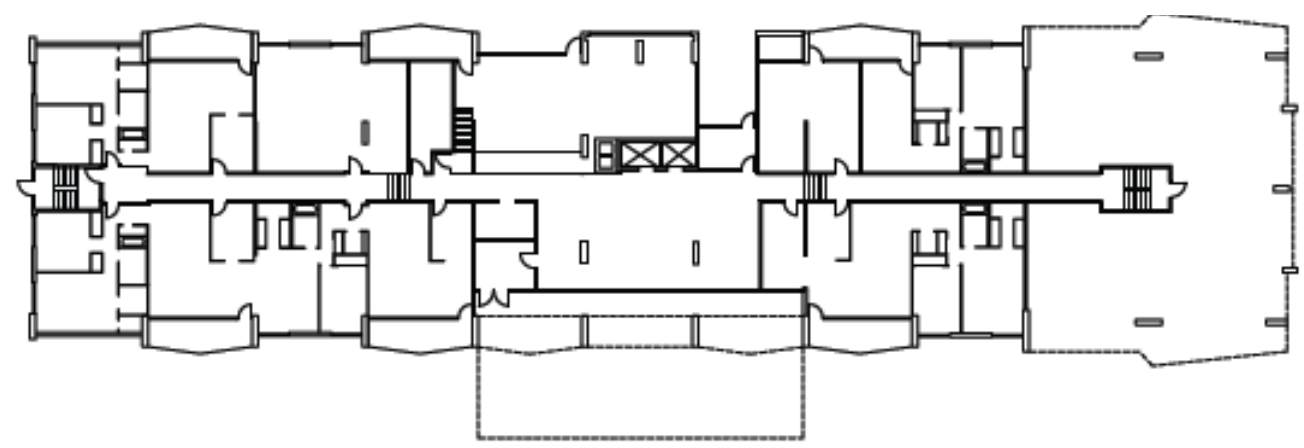

Figure 11-1 Ground Floor Plan (Kesik \& Saleff, 2009)

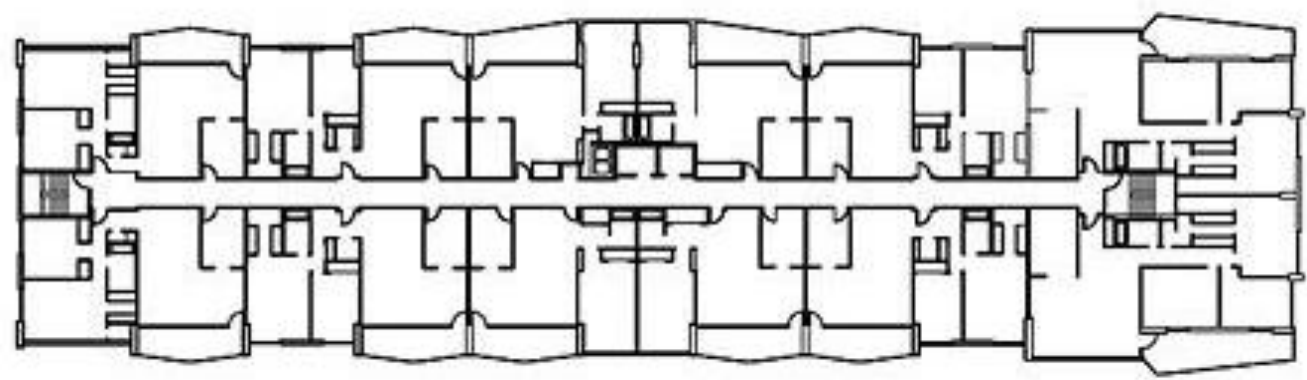

Figure 11-2 Typical Floor Plan (from 2nd to 20th Floor) (Kesik \& Saleff, 2009)

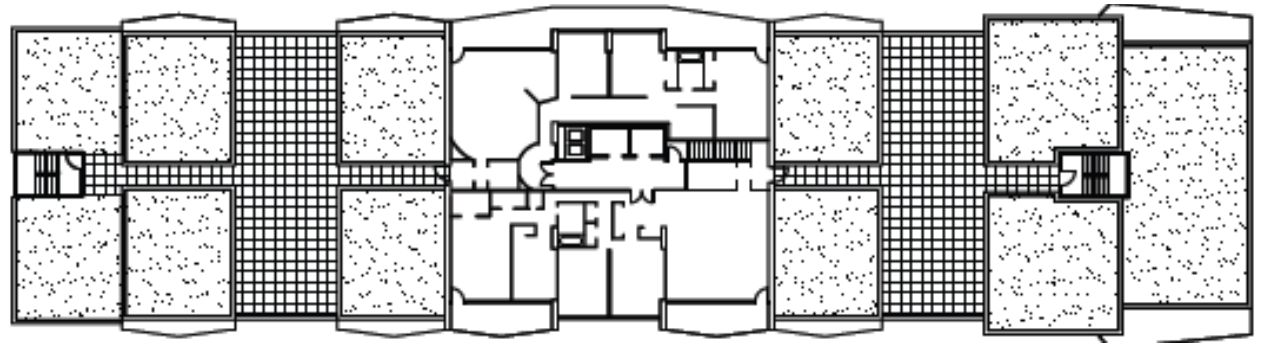

Figure 11-3 Roof Plan (Kesik \& Saleff, 2009)

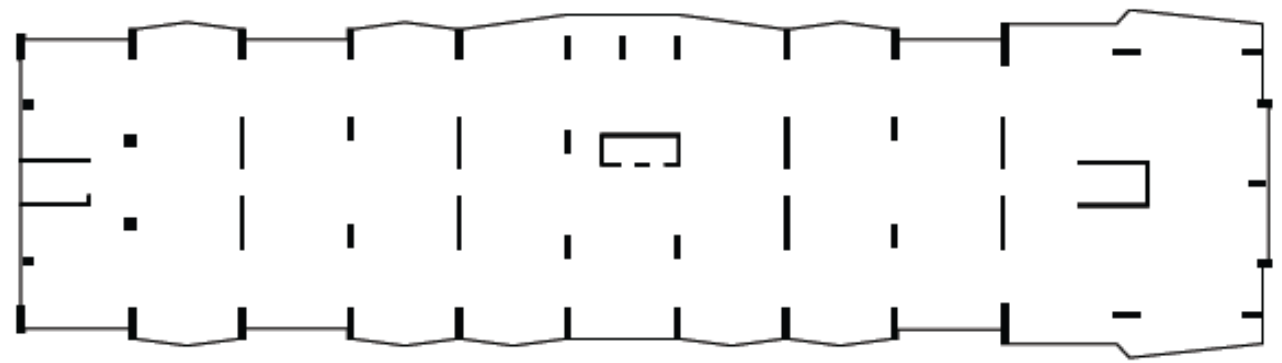

Figure 11-4 Structural Plan (Kesik \& Saleff, 2009) 


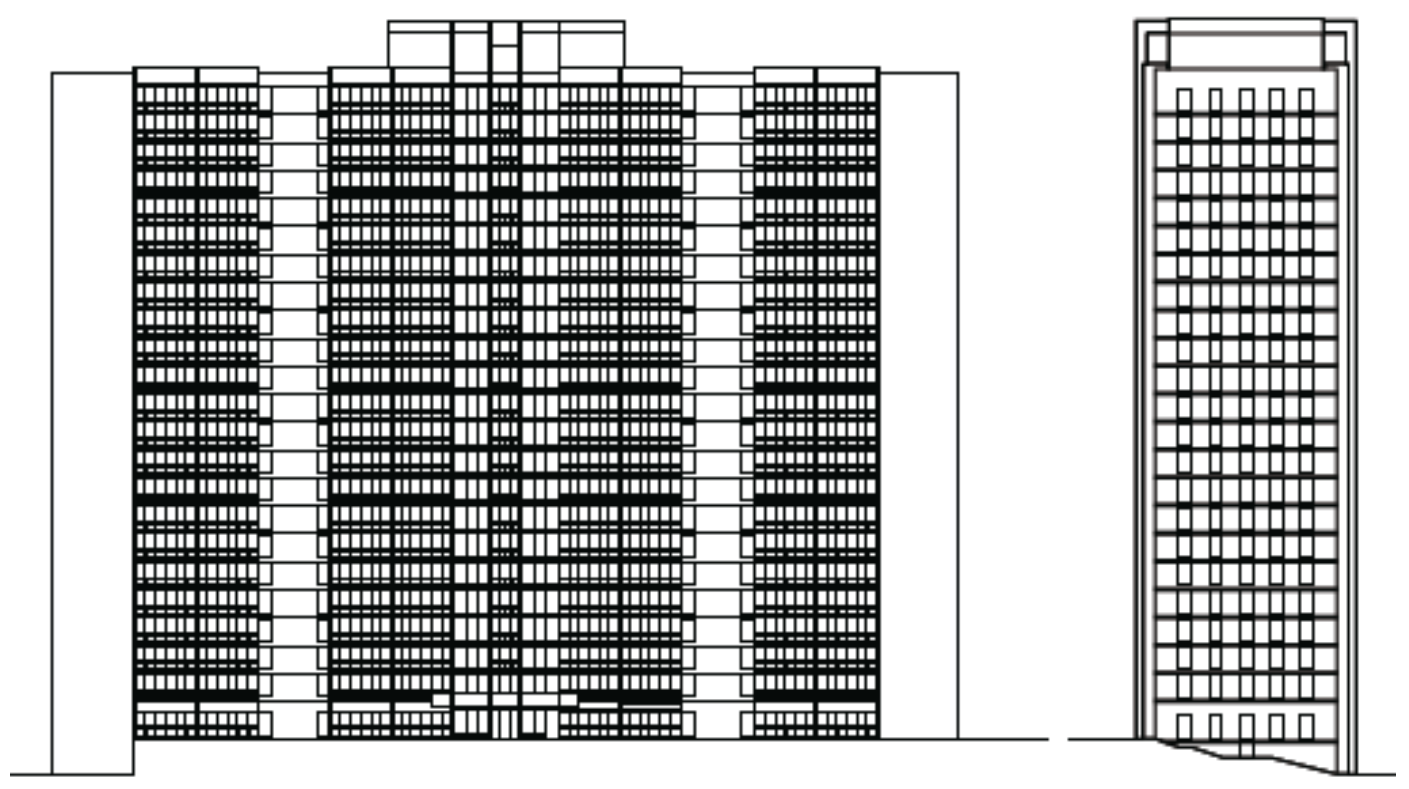

Figure 11-5 Front and Side Elevations (Kesik \& Saleff, 2009) 
11-2 Appendix B: Building Envelope Details

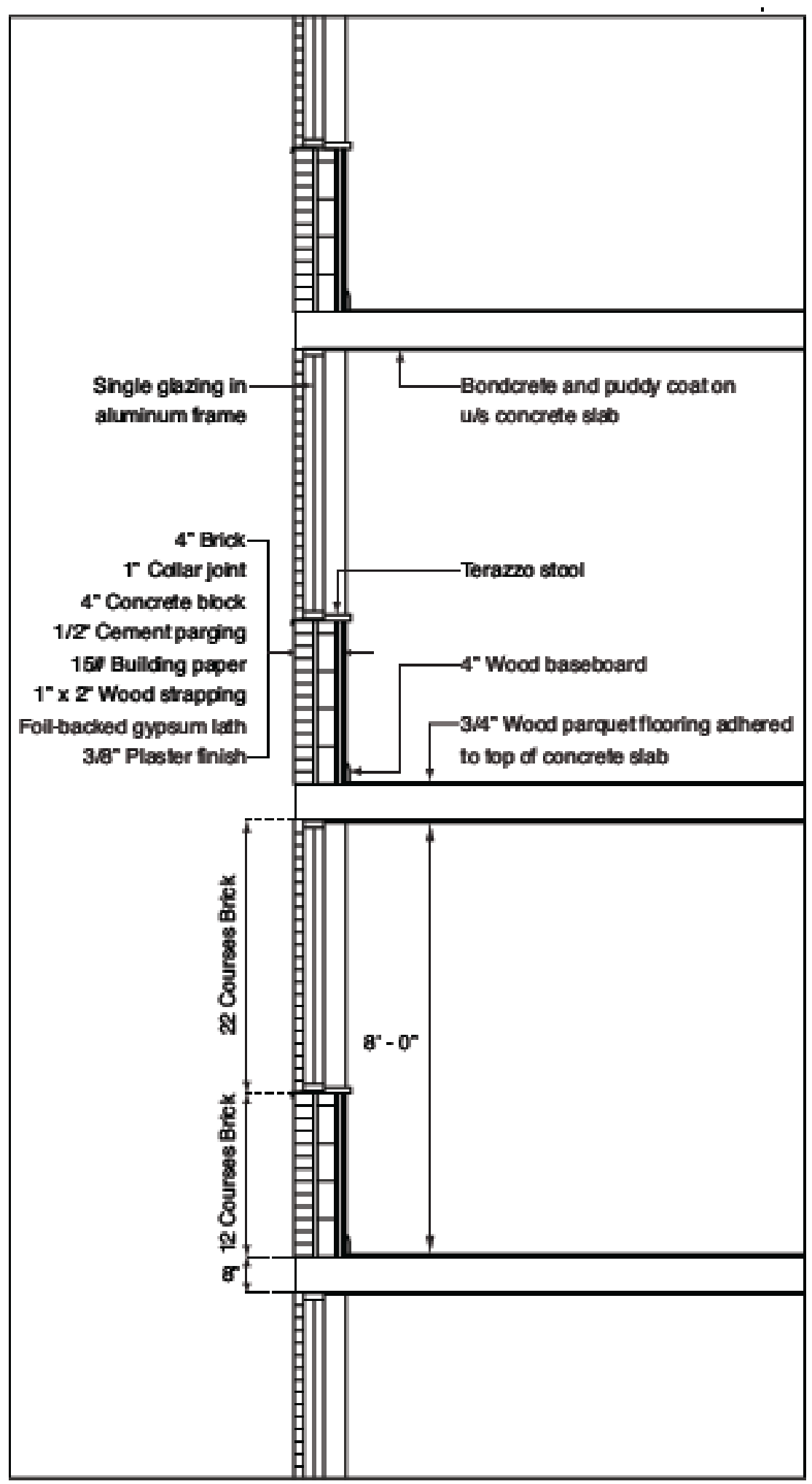

Figure 11-6 Wall Section (Kesik \& Saleff, 2009) 


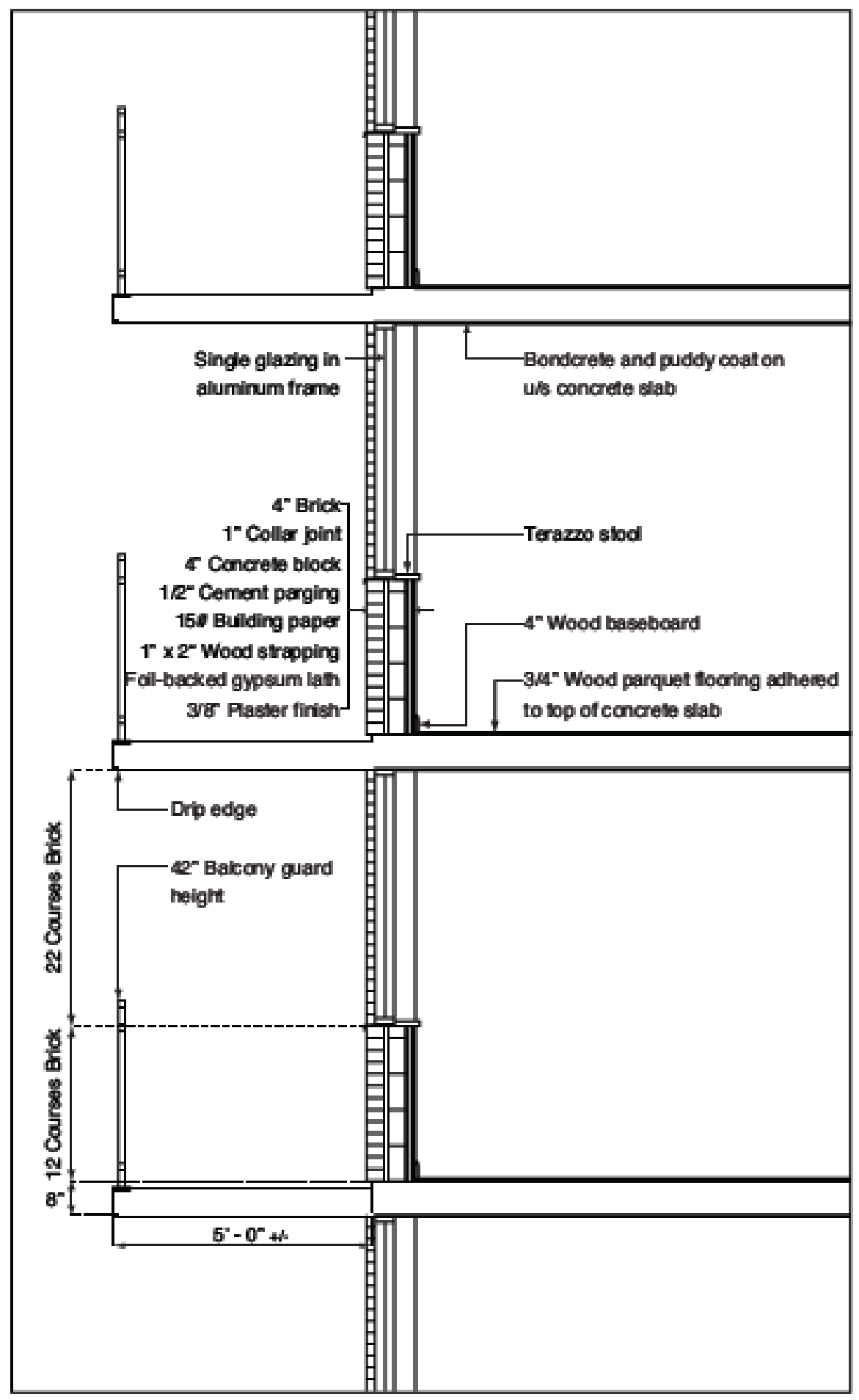

Figure 11-7 Balcony Section (Kesik \& Saleff, 2009) 


\section{1-3 Appendix C: Building Envelope Requirements of Ontario Building Code 2012}

Table 11-1 Climate Zone Numbers for Ontario (SB 10/OBC 2012/ASHRAE 90.1)

Table 5A (Cont'd)

Climatic Zone Numbers for Ontario Locations

(This Table is to be used in conjunction with Tables SB5.5-5 to SB5.5-7)

\begin{tabular}{|l|l|c|l|c|l|l|l|}
\hline No & \multicolumn{1}{|c|}{ Location } & No. & \multicolumn{1}{|c|}{ Location } & No. & \multicolumn{1}{|c|}{ Location } & No. & \multicolumn{1}{c|}{ Location } \\
\hline 6 & Penetanguishene & 7 & Rayside-Balfour & 6 & St. Thomas & 7 & Trout Creek \\
\hline 6 & Perth & 7 & Red Lake & 6 & Stirling & 6 & Uxbridge \\
\hline 7 & Petawawa & 6 & Renfrew & 6 & Strattord & 6 & Vaughan \\
\hline 6 & Peterborough & 6 & Richmond Hill & 5 & Strathroy & 5 & Vittoria \\
\hline 5 & Petrolia & 6 & Rockland & 7 & Sturgeon Falls & 6 & Walkerton \\
\hline 6 & Pickering & 5 & Samia & 7 & Sudbury & 5 & Wallaceburg \\
\hline 6 & Picton & 7 & Sault Ste-Marie & 7 & Sundridge & 6 & Waterloo \\
\hline 6 & Plattsville & 7 & Schreiber & 6 & Tavistock & 5 & Watford \\
\hline 7 & Point Alexander & 6 & Seaforth & 7 & Temagami & 7 & Wawa \\
\hline 6 & Port Burwell & 6 & Simooe & 6 & Thamesford & 5 & Welland \\
\hline 5 & Port Colborne & 7 & Sioux Lookout & 5 & Thedford & 5 & West Lorne \\
\hline 6 & Port Elgin & 6 & Smiths Falls & 7 & Thunder Bay & 6 & Whitby \\
\hline 6 & Port Hope & 5 & Smithville & 6 & Tilsonburg & 7 & White River \\
\hline 6 & Port Perry & 7 & Smooth Rock Falls & 7 & Timmins & 6 & Wiarton \\
\hline 6 & Port Stanley & 6 & Southampton & & Torontol Metropolitan & 5 & Windsor \\
\hline 6 & Prescott & 7 & South River & 6 & $\begin{array}{l}\text { Etobicoke } \\
\text { North York } \\
\text { Scarborough }\end{array}$ & 6 & Wingham \\
\hline 6 & Princeton & 5 & St. Catharines & & 6 & Woodstock \\
\hline 7 & Raith & 6 & St. Marys & 6 & Trenton & 5 & Wyoming \\
\hline
\end{tabular}


Table 11-2 Building Envelope Requirements for Toronto (SB 10/OBC 2012/ASHRAE 90.1)

TABLE SB5.5-6 (See Appendix A) (Supersedes Table 5.5-6 in ANSUASHRAE/IESNA Standard 90.1) Building Envelope Requirements for Climate Zone 6 (A, B) (SI)

\begin{tabular}{|c|c|c|c|c|c|c|}
\hline \multirow[b]{2}{*}{ Opaque Elements } & \multicolumn{2}{|c|}{ Nonresidential } & \multicolumn{2}{|c|}{ Residential } & \multicolumn{2}{|c|}{ Semiheated } \\
\hline & $\begin{array}{c}\text { Assembly } \\
\text { Max. U }\end{array}$ & $\begin{array}{c}\text { Insulation * } \\
\text { Min. RSFValue }\end{array}$ & $\begin{array}{c}\text { Assembly } \\
\text { Max. U }\end{array}$ & $\begin{array}{c}\text { Insulation " } \\
\text { Min. RSLValue }\end{array}$ & $\begin{array}{c}\text { Assembly } \\
\text { Max U }\end{array}$ & $\begin{array}{c}\text { Insulation* } \\
\text { Min. RSHValue }\end{array}$ \\
\hline \multicolumn{7}{|l|}{ Roofs } \\
\hline Insulation Enfrely above Deck & $\mathrm{U}=0.18$ & $5.3 \mathrm{ci}$ & $U-0.18$ & $5.3 \mathrm{~d}$ & $U=0.36$ & $2.6 \mathrm{ci}$ \\
\hline Metal Building & U -0.18 & $4.4+1.9 \mathrm{Ls}$ & U. 0.18 & $4.4+1.9 \mathrm{Ls}$ & $\mathrm{U}=0.39$ & $23+3.3$ \\
\hline Alfe and Other & $\mathrm{U} \cdot 0.12$ & 8.6 & $\mathrm{U}-0.12$ & 8.6 & $\mathrm{U}=0.15$ & 6.7 \\
\hline \multicolumn{7}{|l|}{ Wals, Above Grade } \\
\hline Mass & $U \cdot 0.40$ & $2.7 \mathrm{ci}$ & $\mathrm{U}-0.34$ & $3.5 \mathrm{~d}$ & $\mathrm{U}=0.59$ & $17 \mathrm{ci}$ \\
\hline Metal Builaing & $U=0.30$ & $2.3+2.3 \mathrm{ci}$ & $\mathrm{U} 0.30$ & $2.3+2.3 \mathrm{ci}$ & $\mathrm{U}-0.45$ & $2.3+1.1 \mathrm{~d}$ \\
\hline Sted Framed & $U=0.31$ & $2.3+1.8 \mathrm{ci}$ & $\mathrm{U}-0.31$ & $2.3+1.8 \mathrm{di}$ & $U=0.48$ & $2.3+0.7 \mathrm{~d}$ \\
\hline Wood Framed and Other & $\mathrm{U} \cdot 0.26$ & $2.3+1.8 \mathrm{ci}$ & $\mathrm{U}-0.26$ & $2.3+1.8 \mathrm{di}$ & $\mathrm{U}=0.38$ & $2.3+0.7 \mathrm{di}$ \\
\hline \multicolumn{7}{|l|}{ Wal, Below Grade } \\
\hline Below Grade Wall & $\mathrm{C}-0.52$ & $1.8 \mathrm{ci}$ & $\mathrm{C} .0 .52$ & $1.8 \mathrm{~d}$ & $C-0.68$ & $1.3 \mathrm{ci}$ \\
\hline \multicolumn{7}{|l|}{ Floors } \\
\hline Mass & $U \cdot 0.32$ & $2.6 \mathrm{ci}$ & 40.29 & $2.9 \mathrm{~d}$ & $U=0.61$ & $1.1 \mathrm{ci}$ \\
\hline Steel Joist ${ }^{4}$ & $U \cdot 0.18$ & 6.7 & $\mathrm{U}-0.13$ & $6.7+2.2 \mathrm{di}$ & $U=0.21$ & 5.3 \\
\hline Wood Framed and Other ${ }^{2}$ & $U \cdot 0.15$ & $5.3+1.3 \mathrm{ci}$ & $\cup-15$ & $5.3+1.3 \mathrm{ei}$ & $U=0.19$ & 5.3 \\
\hline \multicolumn{7}{|l|}{ Slab-On-Grade Floors } \\
\hline Unheated & $F=0.90$ & 2.6 for $600 \mathrm{~mm}$ & $F=0.88$ & 3.5 for $600 \mathrm{~mm}$ & $F=0.98$ & 1.8 for $600 \mathrm{~mm}$ \\
\hline Healed & $F=0.76$ & $\begin{array}{c}2.6 \text { for } 900 \mathrm{~mm}+ \\
0.9 \text { di below }\end{array}$ & $F=0.76$ & $\begin{array}{c}2.8 \text { for } 900 \mathrm{~mm}+ \\
0.9 \text { ai below }\end{array}$ & $F \cdot 1.56$ & 1.8 for $600 \mathrm{~mm}$ \\
\hline \multicolumn{7}{|l|}{ Opsque Doors } \\
\hline Swinging & $\mathrm{U} \cdot 2.27$ & & $\cup .2 .27$ & & U.3.41 & \\
\hline Non-Swirging & $\mathrm{U} .2 .27$ & & U.2.27 & & $U-2.84$ & \\
\hline Fenestration & $\begin{array}{c}\text { Assembly } \\
\text { Max. U }\end{array}$ & $\begin{array}{l}\text { Assembly } \\
\text { Max. SHGC }\end{array}$ & $\begin{array}{c}\text { Assembly } \\
\text { Max. U }\end{array}$ & $\begin{array}{l}\text { Assembly } \\
\text { Max. SHGC }\end{array}$ & $\begin{array}{l}\text { Assembly } \\
\text { Max U }\end{array}$ & $\begin{array}{l}\text { Assembly } \\
\text { Max. SHCC }\end{array}$ \\
\hline \multicolumn{7}{|l|}{ Vertical Fenestration, $0 \% \cdot 40 \%$ of Wad } \\
\hline Nonmetal faming al' & {$[0.1 .42$} & \multirow{4}{*}{2.40} & U. $1 . A 2$ & & U.2.56 & \multirow{4}{*}{ NR } \\
\hline Metal taming ourtainwail/ siorefront" & U.199 & & U.1.99 & O. & $U-2 . B 4$ & \\
\hline Metal faming entrance door ${ }^{c}$ & U.3.97 & & U.3.97 & 00,0 & $\mathrm{U}-4.54$ & \\
\hline Metal framing al other ${ }^{c}$ & U.2.56 & & 4.256 & & Uk 3.12 & \\
\hline \multicolumn{7}{|l|}{ Sinylight with Curb, Gloss, \% of Roof } \\
\hline $0 \%=5.0 \%$ & U.3.80 & 0.46 & 4.3 .80 & 0.46 & U.11.24 & NR \\
\hline \multicolumn{7}{|l|}{ Shylight weth Curb, Plasic, \% of Roof } \\
\hline $0 \%=5.0 \%$ & $\mathrm{U} .3 .92$ & 0.49 & U.3.92 & 0.49 & U.10.79 & NR \\
\hline \multicolumn{7}{|l|}{ Sibylight without Curb, $A$ A, \% of Roof } \\
\hline $0 \%=5.0 \%$ & $U \cdot 2.56$ & 0.46 & 4.256 & 0.39 & $\mathrm{U}=7.72$ & NR \\
\hline
\end{tabular}

Reproduced from ANSWSHRAENSGBCIES Standard 189.1-2009 with permission from ASHRAE. 


\section{1-4 Appendix D: Building Envelope Retroit Measures Analysis Resuluts}

\section{OBC 2012 RSI Measures}

Table 11-3 eQuest modeling results based on OBC 2012 RSI measures

\begin{tabular}{|c|c|c|c|c|c|c|c|c|c|c|c|}
\hline BERMs & $\begin{array}{l}\text { Gross } \\
\text { Floor } \\
\text { Area } \\
\left(\mathrm{m}^{2}\right)\end{array}$ & $\begin{array}{c}\text { Gas } \\
\text { Consumption } \\
\text { (Therms) }\end{array}$ & $\begin{array}{c}\text { Gas } \\
\text { Consumption } \\
\text { (kWh) }\end{array}$ & $\begin{array}{c}\text { Gas Consumption } \\
\text { Intensity } \\
\left(\mathrm{kWh} / \mathrm{m}^{2}\right)\end{array}$ & Improvement & $\begin{array}{l}\text { Electricity } \\
\text { Consumption } \\
\text { (kWh) }\end{array}$ & $\begin{array}{c}\text { Electricity } \\
\text { Consumption } \\
\text { Intensity } \\
\left(\mathrm{kWh} / \mathrm{m}^{2}\right)\end{array}$ & Improvement & $\begin{array}{l}\text { Total Energy } \\
\text { Consumption } \\
\text { (kWh) }\end{array}$ & $\begin{array}{c}\text { Energy } \\
\text { Intensity } \\
\left(\mathrm{kWh} / \mathrm{m}^{2}\right)\end{array}$ & Improvement \\
\hline Baseline & 23360.00 & 196,173 & 5749263.11 & 246.12 & & $1,700,870$ & 72.81 & & 7450133.11 & 318.93 & \\
\hline BERM1 & 23360.00 & 194,141 & 5689711.06 & 243.57 & $1.04 \%$ & $1,700,792$ & 72.81 & $0.00 \%$ & 7390503.06 & 316.37 & $0.80 \%$ \\
\hline BERM2 & 23360.00 & 172,343 & 5050874.75 & 216.22 & $12.15 \%$ & $1,699,929$ & 72.77 & $0.06 \%$ & 6750803.75 & 288.99 & $9.39 \%$ \\
\hline BERM3 & 23360.00 & 127,812 & 3745799.96 & 160.35 & $34.85 \%$ & $1,698,059$ & 72.69 & $0.17 \%$ & 5443858.96 & 233.04 & $26.93 \%$ \\
\hline BERM4 & 23360.00 & 191,016 & 5598126.35 & 239.65 & $2.63 \%$ & $1,700,669$ & 72.80 & $0.01 \%$ & 7298795.35 & 312.45 & $2.03 \%$ \\
\hline BERM5 & 23360.00 & 190,659 & 5587663.72 & 239.20 & $2.81 \%$ & $1,700,636$ & 72.80 & $0.01 \%$ & 7288299.72 & 312.00 & $2.17 \%$ \\
\hline BERM6 & 23360.00 & 120,508 & 3531740.85 & 151.19 & $38.57 \%$ & $1,697,770$ & 72.68 & $0.18 \%$ & 5229510.85 & 223.87 & $29.81 \%$ \\
\hline BERM7 & 23360.00 & 91,869 & 2692414.61 & 115.26 & $53.17 \%$ & $1,696,679$ & 72.63 & $0.25 \%$ & 4389093.61 & 187.89 & $41.09 \%$ \\
\hline BERM8 & 23360.00 & 83,802 & 2455994.18 & 105.14 & $57.28 \%$ & $1,696,357$ & 72.62 & $0.27 \%$ & 4152351.18 & 177.75 & $44.26 \%$ \\
\hline
\end{tabular}

\section{Roof Upgrades}

Table 11-4 eQUEST Modeling results for roof upgrade strategy

\begin{tabular}{|c|c|c|c|c|c|c|c|c|c|c|c|}
\hline BERMs & $\begin{array}{l}\text { Gross } \\
\text { Floor } \\
\text { Area } \\
\left(\mathrm{m}^{2}\right)\end{array}$ & $\begin{array}{c}\text { Gas } \\
\text { Consumption } \\
\text { (Therms) }\end{array}$ & $\begin{array}{c}\text { Gas } \\
\text { Consumption } \\
\text { (kWh) }\end{array}$ & $\begin{array}{c}\text { Gas Consumption } \\
\text { Intensity } \\
\left(\mathrm{kWh} / \mathrm{m}^{2}\right)\end{array}$ & Improvement & $\begin{array}{l}\text { Electricity } \\
\text { Consumption } \\
\text { (kWh) }\end{array}$ & $\begin{array}{l}\text { Electricity } \\
\text { Consumption } \\
\text { Intensity } \\
\left(\mathrm{kWh} / \mathrm{m}^{2}\right)\end{array}$ & Improvement & $\begin{array}{c}\text { Total Energy } \\
\text { Consumption } \\
\text { (kWh) }\end{array}$ & $\begin{array}{c}\text { Energy } \\
\text { Intensity } \\
\left(\mathrm{kWh} / \mathrm{m}^{2}\right)\end{array}$ & Improvement \\
\hline Baseline & 23360.00 & 196,173 & 5749263.11 & 246.12 & & $1,700,870$ & 72.81 & & 7450133.11 & 318.93 & \\
\hline BERM9 & 23360.00 & 194,425 & 5698034.28 & 243.92 & $0.89 \%$ & $1,700,807$ & 72.81 & $0.00 \%$ & 7398841.28 & 316.73 & $0.69 \%$ \\
\hline BERM10 & 23360.00 & 194,320 & 5694957.04 & 243.79 & $0.94 \%$ & $1,700,802$ & 72.81 & $0.00 \%$ & 7395759.04 & 316.60 & $0.73 \%$ \\
\hline BERM11 & 23360.00 & 194,224 & 5692143.55 & 243.67 & $0.99 \%$ & $1,700,796$ & 72.81 & $0.00 \%$ & 7392939.55 & 316.48 & $0.77 \%$ \\
\hline BERM12 & 23360.00 & 194,141 & 5689711.06 & 243.57 & $1.04 \%$ & $1,700,792$ & 72.81 & $0.00 \%$ & 7390503.06 & 316.37 & $0.80 \%$ \\
\hline BERM13 & 23360.00 & 194,074 & 5687747.49 & 243.48 & $1.07 \%$ & $1,700,788$ & 72.81 & $0.00 \%$ & 7388535.49 & 316.29 & $0.83 \%$ \\
\hline BERM14 & 23360.00 & 194,021 & 5686194.21 & 243.42 & $1.10 \%$ & $1,700,788$ & 72.81 & $0.00 \%$ & 7386982.21 & 316.22 & $0.85 \%$ \\
\hline
\end{tabular}


Over-Cladding Wall and Balcony Slab

Table 11-5 eQUEST Modelin results for over-cladding wall and balcony slab strategy

\begin{tabular}{|c|c|c|c|c|c|c|c|c|c|c|c|}
\hline BERMs & $\begin{array}{l}\text { Gross } \\
\text { Floor } \\
\text { Area } \\
\left(\mathrm{m}^{2}\right)\end{array}$ & $\begin{array}{c}\text { Gas } \\
\text { Consumption } \\
\text { (Therms) }\end{array}$ & $\begin{array}{c}\text { Gas } \\
\text { Consumption } \\
\text { (kWh) }\end{array}$ & $\begin{array}{c}\text { Gas Consumption } \\
\text { Intensity } \\
\left(\mathrm{kWh} / \mathrm{m}^{2}\right)\end{array}$ & Improvement & $\begin{array}{l}\text { Electricity } \\
\text { Consumption } \\
\text { (kWh) }\end{array}$ & $\begin{array}{l}\text { Electricity } \\
\text { Consumption } \\
\text { Intensity } \\
\left(\mathrm{kWh} / \mathrm{m}^{2}\right)\end{array}$ & Improvement & $\begin{array}{l}\text { Total Energy } \\
\text { Consumption } \\
\text { (kWh) }\end{array}$ & $\begin{array}{c}\text { Energy } \\
\text { Intensity } \\
\left(\mathrm{kWh} / \mathrm{m}^{2}\right)\end{array}$ & Improvement \\
\hline Baseline & 23360.00 & 196,173 & 5749263.11 & 246.12 & & $1,700,870$ & 72.81 & & 7450133.11 & 318.93 & \\
\hline BERM15 & 23360.00 & 135,152 & 3960914.13 & 169.56 & $31.11 \%$ & $1,698,356$ & 72.70 & $0.15 \%$ & 5659270.13 & 242.26 & $24.04 \%$ \\
\hline BERM16 & 23360.00 & 128,968 & 3779678.98 & 161.80 & $34.26 \%$ & $1,698,103$ & 72.69 & $0.16 \%$ & 5477781.98 & 234.49 & $26.47 \%$ \\
\hline BERM17 & 23360.00 & 125,444 & 3676400.73 & 157.38 & $36.05 \%$ & $1,697,962$ & 72.69 & $0.17 \%$ & 5374362.73 & 230.07 & $27.86 \%$ \\
\hline BERM18 & 23360.00 & 124,090 & 3636718.91 & 155.68 & $36.74 \%$ & $1,697,909$ & 72.68 & $0.17 \%$ & 5334627.91 & 228.37 & $28.40 \%$ \\
\hline BERM19 & 23360.00 & 121,501 & 3560842.81 & 152.43 & $38.06 \%$ & $1,697,806$ & 72.68 & $0.18 \%$ & 5258648.81 & 225.11 & $29.42 \%$ \\
\hline BERM20 & 23360.00 & 120,508 & 3531740.85 & 151.19 & $38.57 \%$ & $1,697,770$ & 72.68 & $0.18 \%$ & 5229510.85 & 223.87 & $29.81 \%$ \\
\hline BERM21 & 23360.00 & 118,667 & 3477786.47 & 148.88 & $39.51 \%$ & $1,697,707$ & 72.68 & $0.19 \%$ & 5175493.47 & 221.55 & $30.53 \%$ \\
\hline
\end{tabular}

\section{Window Upgrades (Aluminum Frame without Thermal Break)}

Table 11-6 eQUEST Modeling results for window replacement (Aluminum frame without thermal break) strategy

\begin{tabular}{|c|c|c|c|c|c|c|c|c|c|c|c|}
\hline BERMs & $\begin{array}{l}\text { Gross } \\
\text { Floor } \\
\text { Area } \\
\left(\mathrm{m}^{2}\right)\end{array}$ & $\begin{array}{c}\text { Gas } \\
\text { Consumption } \\
\text { (Therms) }\end{array}$ & $\begin{array}{c}\text { Gas } \\
\text { Consumption } \\
\text { (kWh) }\end{array}$ & $\begin{array}{c}\text { Gas Consumption } \\
\text { Intensity } \\
\left(\mathrm{kWh} / \mathrm{m}^{2}\right)\end{array}$ & Improvement & $\begin{array}{l}\text { Electricity } \\
\text { Consumption } \\
\text { (kWh) }\end{array}$ & $\begin{array}{l}\text { Electricity } \\
\text { Consumption } \\
\text { Intensity } \\
\left(\mathrm{kWh} / \mathrm{m}^{2}\right)\end{array}$ & Improvement & $\begin{array}{l}\text { Total Energy } \\
\text { Consumption } \\
\text { (kWh) }\end{array}$ & $\begin{array}{c}\text { Energy } \\
\text { Intensity } \\
\left(\mathrm{kWh} / \mathrm{m}^{2}\right)\end{array}$ & Improvement \\
\hline Baseline & 23360.00 & 196,173 & 5749263.11 & 246.12 & & $1,700,870$ & 72.81 & & 7450133.11 & 318.93 & \\
\hline BERM22 & 23360.00 & 177,567 & 5203975.07 & 222.77 & $9.48 \%$ & $1,700,154$ & 72.78 & $0.04 \%$ & 6904129.07 & 295.55 & $7.33 \%$ \\
\hline BERM23 & 23360.00 & 174,718 & 5120479.12 & 219.20 & $10.94 \%$ & $1,700,037$ & 72.78 & $0.05 \%$ & 6820516.12 & 291.97 & $8.45 \%$ \\
\hline BERM24 & 23360.00 & 171,690 & 5031737.20 & 215.40 & $12.48 \%$ & $1,699,898$ & 72.77 & $0.06 \%$ & 6731635.20 & 288.17 & $9.64 \%$ \\
\hline BERM25 & 23360.00 & 169,697 & 4973328.14 & 212.90 & $13.50 \%$ & $1,699,818$ & 72.77 & $0.06 \%$ & 6673146.14 & 285.67 & $10.43 \%$ \\
\hline BERM26 & 23360.00 & 173,872 & 5095685.31 & 218.14 & $11.37 \%$ & $1,700,001$ & 72.77 & $0.05 \%$ & 6795686.31 & 290.91 & $8.78 \%$ \\
\hline BERM27 & 23360.00 & 173,109 & 5073323.99 & 217.18 & $11.76 \%$ & $1,699,964$ & 72.77 & $0.05 \%$ & 6773287.99 & 289.95 & $9.09 \%$ \\
\hline BERM28 & 23360.00 & 169,577 & 4969811.29 & 212.75 & $13.56 \%$ & $1,699,813$ & 72.77 & $0.06 \%$ & 6669624.29 & 285.51 & $10.48 \%$ \\
\hline BERM29 & 23360.00 & 167,143 & 4898477.79 & 209.70 & $14.80 \%$ & $1,699,711$ & 72.76 & $0.07 \%$ & 6598188.79 & 282.46 & $11.44 \%$ \\
\hline
\end{tabular}


Window Upgrades (Aluminum Frame with Thermal Break)

Table 11-7 eQUEST Modeling results for window replacement (Aluminum frame with insulated thermal break) strategy

\begin{tabular}{|c|c|c|c|c|c|c|c|c|c|c|c|}
\hline BERMs & $\begin{array}{l}\text { Gross } \\
\text { Floor } \\
\text { Area } \\
\left(\mathrm{m}^{2}\right)\end{array}$ & $\begin{array}{c}\text { Gas } \\
\text { Consumption } \\
\text { (Therms) }\end{array}$ & $\begin{array}{c}\text { Gas } \\
\text { Consumption } \\
\text { (kWh) }\end{array}$ & $\begin{array}{c}\text { Gas Consumption } \\
\text { Intensity } \\
\left(\mathrm{kWh} / \mathrm{m}^{2}\right)\end{array}$ & Improvement & $\begin{array}{l}\text { Electricity } \\
\text { Consumption } \\
\text { (kWh) }\end{array}$ & $\begin{array}{l}\text { Electricity } \\
\text { Consumption } \\
\text { Intensity } \\
\left(\mathrm{kWh} / \mathrm{m}^{2}\right)\end{array}$ & Improvement & $\begin{array}{l}\text { Total Energy } \\
\text { Consumption } \\
(\mathrm{kWh})\end{array}$ & $\begin{array}{c}\text { Energy } \\
\text { Intensity } \\
\left(\mathrm{kWh} / \mathrm{m}^{2}\right)\end{array}$ & Improvement \\
\hline Baseline & 23360.00 & 196,173 & 5749263.11 & 246.12 & & $1,700,870$ & 72.81 & & 7450133.11 & 318.93 & \\
\hline BERM30 & 23360.00 & 174,868 & 5124875.19 & 219.39 & $10.86 \%$ & $1,700,043$ & 72.78 & $0.05 \%$ & 6824918.19 & 292.16 & $8.39 \%$ \\
\hline BERM31 & 23360.00 & 171,965 & 5039796.66 & 215.74 & $12.34 \%$ & $1,699,915$ & 72.77 & $0.06 \%$ & 6739711.66 & 288.52 & $9.54 \%$ \\
\hline BERM32 & 23360.00 & 168,890 & 4949677.30 & 211.89 & $13.91 \%$ & $1,699,785$ & 72.76 & $0.06 \%$ & 6649462.30 & 284.65 & $10.75 \%$ \\
\hline BERM33 & 23360.00 & 166,890 & 4891063.09 & 209.38 & $14.93 \%$ & $1,699,695$ & 72.76 & $0.07 \%$ & 6590758.09 & 282.14 & $11.54 \%$ \\
\hline BERM34 & 23360.00 & 170,913 & 5008965.58 & 214.42 & $12.88 \%$ & $1,699,868$ & 72.77 & $0.06 \%$ & 6708833.58 & 287.19 & $9.95 \%$ \\
\hline BERM35 & 23360.00 & 170,138 & 4986252.57 & 213.45 & $13.27 \%$ & $1,699,832$ & 72.77 & $0.06 \%$ & 6686084.57 & 286.22 & $10.26 \%$ \\
\hline BERM36 & 23360.00 & 166,613 & 4882945.02 & 209.03 & $15.07 \%$ & $1,699,687$ & 72.76 & $0.07 \%$ & 6582632.02 & 281.79 & $11.64 \%$ \\
\hline BERM37 & 23360.00 & 164,144 & 4810585.77 & 205.93 & $16.33 \%$ & $1,699,580$ & 72.76 & $0.08 \%$ & 6510165.77 & 278.69 & $12.62 \%$ \\
\hline
\end{tabular}

Window Upgrades (Insulated Fiberglass Frame with Thermal Break)

Table 11-8 eQUEST Modeling results for window replacement (Insulated fiberglass frame with insulated thermal break) strategy

\begin{tabular}{|c|c|c|c|c|c|c|c|c|c|c|c|}
\hline BERMs & $\begin{array}{l}\text { Gross } \\
\text { Floor } \\
\text { Area } \\
\left(\mathrm{m}^{2}\right)\end{array}$ & $\begin{array}{c}\text { Gas } \\
\text { Consumption } \\
\text { (Therms) }\end{array}$ & $\begin{array}{c}\text { Gas } \\
\text { Consumption } \\
\text { (kWh) }\end{array}$ & $\begin{array}{c}\text { Gas Consumption } \\
\text { Intensity } \\
\left(\mathrm{kWh} / \mathrm{m}^{2}\right)\end{array}$ & Improvement & $\begin{array}{l}\text { Electricity } \\
\text { Consumption } \\
\text { (kWh) }\end{array}$ & $\begin{array}{l}\text { Electricity } \\
\text { Consumption } \\
\text { Intensity } \\
\left(\mathrm{kWh} / \mathrm{m}^{2}\right)\end{array}$ & Improvement & $\begin{array}{l}\text { Total Energy } \\
\text { Consumption } \\
\text { (kWh) }\end{array}$ & $\begin{array}{c}\text { Energy } \\
\text { Intensity } \\
\left(\mathrm{kWh} / \mathrm{m}^{2}\right)\end{array}$ & Improvement \\
\hline Baseline & 23360.00 & 196,173 & 5749263.11 & 246.12 & & $1,700,870$ & 72.81 & & 7450133.11 & 318.93 & \\
\hline BERM38 & 23360.00 & 173,326 & 5079683.63 & 217.45 & $11.65 \%$ & $1,699,967$ & 72.77 & $0.05 \%$ & 6779650.63 & 290.22 & $9.00 \%$ \\
\hline BERM39 & 23360.00 & 170,376 & 4993227.67 & 213.75 & $13.15 \%$ & $1,699,842$ & 72.77 & $0.06 \%$ & 6693069.67 & 286.52 & $10.16 \%$ \\
\hline BERM40 & 23360.00 & 167,308 & 4903313.46 & 209.90 & $14.71 \%$ & $1,699,715$ & 72.76 & $0.07 \%$ & 6603028.46 & 282.66 & $11.37 \%$ \\
\hline BERM41 & 23360.00 & 165,312 & 4844816.48 & 207.40 & $15.73 \%$ & $1,699,631$ & 72.76 & $0.07 \%$ & 6544447.48 & 280.16 & $12.16 \%$ \\
\hline BERM42 & 23360.00 & 169,431 & 4965532.45 & 212.57 & $13.63 \%$ & $1,699,803$ & 72.77 & $0.06 \%$ & 6665335.45 & 285.33 & $10.53 \%$ \\
\hline BERM43 & 23360.00 & 168,671 & 4943259.05 & 211.61 & $14.02 \%$ & $1,699,776$ & 72.76 & $0.06 \%$ & 6643035.05 & 284.38 & $10.83 \%$ \\
\hline BERM44 & 23360.00 & 165,113 & 4838984.36 & 207.15 & $15.83 \%$ & $1,699,621$ & 72.76 & $0.07 \%$ & 6538605.36 & 279.91 & $12.24 \%$ \\
\hline BERM45 & 23360.00 & 162,615 & 4765775.21 & 204.01 & $17.11 \%$ & $1,699,514$ & 72.75 & $0.08 \%$ & 6465289.21 & 276.77 & $13.22 \%$ \\
\hline
\end{tabular}


Ground Floor Slab Upgrades

Table 11-9 eQUEST Modeling results for ground floor slab insulation strategy

\begin{tabular}{|c|c|c|c|c|c|c|c|c|c|c|c|}
\hline BERMs & $\begin{array}{l}\text { Gross } \\
\text { Floor } \\
\text { Area } \\
\left(\mathrm{m}^{2}\right)\end{array}$ & $\begin{array}{c}\text { Gas } \\
\text { Consumption } \\
\text { (Therms) }\end{array}$ & $\begin{array}{c}\text { Gas } \\
\text { Consumption } \\
\text { (kWh) }\end{array}$ & $\begin{array}{c}\text { Gas Consumption } \\
\text { Intensity } \\
\left(\mathrm{kWh} / \mathrm{m}^{2}\right)\end{array}$ & Improvement & $\begin{array}{l}\text { Electricity } \\
\text { Consumption } \\
\text { (kWh) }\end{array}$ & $\begin{array}{l}\text { Electricity } \\
\text { Consumption } \\
\text { Intensity } \\
\left(\mathrm{kWh} / \mathrm{m}^{2}\right)\end{array}$ & Improvement & $\begin{array}{l}\text { Total Energy } \\
\text { Consumption } \\
\text { (kWh) }\end{array}$ & $\begin{array}{c}\text { Energy } \\
\text { Intensity } \\
\left(\mathrm{kWh} / \mathrm{m}^{2}\right)\end{array}$ & Improvement \\
\hline Baseline & 23360.00 & 196,173 & 5749263.11 & 246.12 & & $1,700,870$ & 72.81 & & 7450133.11 & 318.93 & \\
\hline BERM46 & 23360.00 & 192,695 & 5647332.99 & 241.75 & $1.77 \%$ & $1,700,722$ & 72.80 & $0.01 \%$ & 7348054.99 & 314.56 & $1.37 \%$ \\
\hline BERM47 & 23360.00 & 191,796 & 5620985.90 & 240.62 & $2.23 \%$ & $1,700,685$ & 72.80 & $0.01 \%$ & 7321670.90 & 313.43 & $1.72 \%$ \\
\hline BERM48 & 23360.00 & 191,338 & 5607563.24 & 240.05 & $2.46 \%$ & $1,700,665$ & 72.80 & $0.01 \%$ & 7308228.24 & 312.85 & $1.90 \%$ \\
\hline BERM49 & 23360.00 & 190,863 & 5593642.37 & 239.45 & $2.71 \%$ & $1,700,645$ & 72.80 & $0.01 \%$ & 7294287.37 & 312.26 & $2.09 \%$ \\
\hline BERM50 & 23360.00 & 190,659 & 5587663.72 & 239.20 & $2.81 \%$ & $1,700,636$ & 72.80 & $0.01 \%$ & 7288299.72 & 312.00 & $2.17 \%$ \\
\hline BERM51 & 23360.00 & 190,649 & 5587370.65 & 239.19 & $2.82 \%$ & $1,700,636$ & 72.80 & $0.01 \%$ & 7288006.65 & 311.99 & $2.18 \%$ \\
\hline BERM52 & 23360.00 & 190,613 & 5586315.59 & 239.14 & $2.83 \%$ & $1,700,634$ & 72.80 & $0.01 \%$ & 7286949.59 & 311.94 & $2.19 \%$ \\
\hline
\end{tabular}

\section{Airtightness Upgrades}

Table 11-10 eQUEST Modeling results for airtightness strategy

\begin{tabular}{|c|c|c|c|c|c|c|c|c|c|c|c|}
\hline BERMs & $\begin{array}{l}\text { Gross } \\
\text { Floor } \\
\text { Area } \\
\left(\mathrm{m}^{2}\right)\end{array}$ & $\begin{array}{c}\text { Gas } \\
\text { Consumption } \\
\text { (Therms) }\end{array}$ & $\begin{array}{c}\text { Gas } \\
\text { Consumption } \\
\text { (kWh) }\end{array}$ & $\begin{array}{c}\text { Gas Consumption } \\
\text { Intensity } \\
\left(\mathrm{kWh} / \mathrm{m}^{2}\right)\end{array}$ & Improvement & $\begin{array}{l}\text { Electricity } \\
\text { Consumption } \\
\text { (kWh) }\end{array}$ & $\begin{array}{l}\text { Electricity } \\
\text { Consumption } \\
\text { Intensity } \\
\left(\mathrm{kWh} / \mathrm{m}^{2}\right)\end{array}$ & Improvement & $\begin{array}{c}\text { Total Energy } \\
\text { Consumption } \\
\text { (kWh) }\end{array}$ & $\begin{array}{c}\text { Energy } \\
\text { Intensity } \\
\left(\mathrm{kWh} / \mathrm{m}^{2}\right)\end{array}$ & Improvement \\
\hline Baseline & 23360.00 & 196,173 & 5749263.11 & 246.12 & & $1,700,870$ & 72.81 & & 7450133.11 & 318.93 & \\
\hline BERM53 & 23360.00 & 182,660 & 5353236.17 & 229.16 & $6.89 \%$ & $1,700,346$ & 72.79 & $0.03 \%$ & 7053582.17 & 301.95 & $5.32 \%$ \\
\hline BERM54 & 23360.00 & 168,026 & 4924355.96 & 210.80 & $14.35 \%$ & $1,699,729$ & 72.76 & $0.07 \%$ & 6624084.96 & 283.57 & $11.09 \%$ \\
\hline BERM55 & 23360.00 & 152,664 & 4474140.19 & 191.53 & $22.18 \%$ & $1,699,083$ & 72.73 & $0.11 \%$ & 6173223.19 & 264.26 & $17.14 \%$ \\
\hline BERM56 & 23360.00 & 144,795 & 4243522.56 & 181.66 & $26.19 \%$ & $1,698,755$ & 72.72 & $0.12 \%$ & 5942277.56 & 254.38 & $20.24 \%$ \\
\hline BERM57 & 23360.00 & 140,820 & 4127026.81 & 176.67 & $28.22 \%$ & $1,698,605$ & 72.71 & $0.13 \%$ & 5825631.81 & 249.38 & $21.80 \%$ \\
\hline BERM58 & 23360.00 & 138,825 & 4068559.13 & 174.17 & $29.23 \%$ & $1,698,517$ & 72.71 & $0.14 \%$ & 5767076.13 & 246.88 & $22.59 \%$ \\
\hline
\end{tabular}


Comprehensive Building Envelope Retrofit and Airtightness Upgrades

Table 11-11 eQUEST Modeling results for comprehensive building envelope retrofit and airtightness strategy

\begin{tabular}{|c|c|c|c|c|c|c|c|c|c|c|c|}
\hline BERMs & $\begin{array}{l}\text { Gross } \\
\text { Floor } \\
\text { Area } \\
\left(\mathrm{m}^{2}\right)\end{array}$ & $\begin{array}{c}\text { Gas } \\
\text { Consumption } \\
\text { (Therms) }\end{array}$ & $\begin{array}{c}\text { Gas } \\
\text { Consumption } \\
(\mathrm{kWh})\end{array}$ & $\begin{array}{c}\text { Gas Consumption } \\
\text { Intensity } \\
\left(\mathrm{kWh} / \mathrm{m}^{2}\right)\end{array}$ & Improvement & $\begin{array}{l}\text { Electricity } \\
\text { Consumption } \\
(\mathrm{kWh})\end{array}$ & $\begin{array}{l}\text { Electricity } \\
\text { Consumption } \\
\text { Intensity } \\
\left(\mathrm{kWh} / \mathrm{m}^{2}\right)\end{array}$ & Improvement & $\begin{array}{l}\text { Total Energy } \\
\text { Consumption } \\
\text { (kWh) }\end{array}$ & $\begin{array}{l}\text { Energy } \\
\text { Intensity } \\
\left(\mathrm{kWh} / \mathrm{m}^{2}\right)\end{array}$ & Improvement \\
\hline Baseline & 23360.00 & 196,173 & 5749263.11 & 246.12 & & $1,700,870$ & 72.81 & & 7450133.11 & 318.93 & \\
\hline BERM 59 & 23360.00 & 51,939 & 1522181.83 & 65.16 & $73.52 \%$ & $1,695,141$ & 72.57 & $0.34 \%$ & 3217322.83 & 137.73 & $56.82 \%$ \\
\hline BERM 60 & 23360.00 & 41,945 & 1229286.60 & 52.62 & $78.62 \%$ & $1,694,703$ & 72.55 & $0.36 \%$ & 2923989.60 & 125.17 & $60.75 \%$ \\
\hline BERM 61 & 23360.00 & 42,411 & 1242943.72 & 53.21 & $78.38 \%$ & $1,694,715$ & 72.55 & $0.36 \%$ & 2937658.72 & 125.76 & $60.57 \%$ \\
\hline
\end{tabular}




\section{Bibliography}

Anis, W. (2005). Commissioning the Air Barrier System. ASHRAE Journal, 35-41.

ARUP Group. (2010). City of Toronto Mayor's Tower Renewal Community Energy Plan for Pilot Sites. . Toronto: City of Toronto.

ASHRAE. ( 1980). ASHRAE Standard 90A-1980, energy conservation in new building design. Atlanta: American Society of Heating Refrigerating and Airconditioning Engineers.

ASHRAE. (1975). ASHRAE Standard 90-1975, energy conservation in new building design. . Atlanta: American Society of Heating Refrigerating and Airconditioning Engineers.

ASHRAE. (2013). ANSI/ASHRAE/IES Standard 90.1-2013. Energys standard for buildings except low-rise residential buildings. Atlanta: American Society of Heating Refrigerating and Air-conditioning Engineers. Retrieved from http://openpub.realread.com/rrserver/browser?title=/ASHRAE_1/ashrae_90_1_2013_12 80

Baker, P. (2012). Measure Guideline: Wood Window Repair, Rehabilitation, and Replacement. Oak Ridge: Building Science Corporation, U.S. Department of Energy.

Barrios, \& Huelsz. (2012). Envelope wall/roof thermal performance parameters for non-airconditioned buildings. Energy \& Buildings, 50, 120-127.

Chow, W., \& Philip, Y. (1998). Controlling building energy use by overall thermal transfer value (OTTV). Energy 2000;(25(5)), 463-478.

Clayton Research Associates. (1984). Conservation of Ontario's High-Rise Housing Stock, Housing Renovation and Energy Conservation Unit. Toronto: Ontario Ministry of Municipal Affairs and Housing.

CMHC. (1990). Extend of Carbonation in Buildings in Toronto. Ottawa: Canada Mortgage and Housing Corporation.

CMHC. (1999). Analysis of the Annual Energy and Water Consumption of Apartment Buildings in the CMHC HiSTAR Database. . Ottawa: Canada Mortgage and Housing Corporation. Retrieved from http://www.cmhc-schl.gc.ca/publications/en/rh-pr/tech/tech01-142.htm

CMHC. (1999). Corridor Air Ventilation System Energy Use In Multi-Unit Residential Buildings. Ottawa: Canada Mortgage ang Housing.

CMHC. (2000). Review of OHC Building Energy and Water Audits. . Ottawa: Canada Mortgage and Housing Corporatio. Retrieved from http://dsp-psd.pwgsc.gc.ca/Collection/NH18-22100-110E.pdf 
CMHC. (2002). Healthy High-Rise: A Guide to Innovation in the Design and Construction of High-Rise Residential Buildings. Ottawa: Canada Mortgage and Gousing Corporation. Retrieved from http://www.cmhc-schl.gc.ca/odpub/pdf/62876.pdf?lang=en

CMHC. (2003). Strategies for Reducing Building Energy Use Via Innovative Building Envelope Technologies: Final Report. Ottawa: Canada Mortgage and Housing Corporation.

CMHC. (2003). Ventilation Systems for Multi-Unit Residential Buildings:Performance Requirements and Alternative Approaches. Ottawa: Canada Mortgage and Housing Corporation. Retrieved from http://www.cmhc-schl.gc.ca/odpub/pdf/63280.pdf?lang=en

CMHC. (2005). Energy and Water Consumption Load Profiles in Multi-Unit Residential Buildings. . Ottawa: Canada Mortgade and Housong Corporation. Retrieved from http://dsp-psd.pwgsc.gc.ca/Collection/NH18-22-105-119E.pdf

CMHC. (2006). A Guide to Innovation in the Design and Construction of High-Rise Residential Buildings. Ottawa: Canada Mortgage and Housing Corporation. Retrieved from http://www.cmhc-schl.gc.ca/en/inpr/bude/himu/hehi/upload/Enhancing-EnergyPerformance.pdf

CMHC. (2007). Air Leakage Control Manua:IExisting Multi-Unit Residential Buildings. Ottawa: Canada Mortgage and Housing Corporation.

CMHC. (2007). Air Leakage Control Manual Existing Multi-Unit Residential Buildings. Ottawa: Canada Mortgage and Housing Corporation.

Craven, C. M., \& Garber-Slaght, R. L. (2012). Exterior Insulation Envelope Retrofits in SubArctic Environments. Seventh International Cold Climate HVAC Conference. Calgary: ASHRAE. Retrieved from http://www.cchrc.org/docs/reports/Exterior_Insulation_Envelope_Retrofits.pdf

Crawley, D. (N/A). EVALUATING THE COST-EFFECTIVENESS OF BUILDING ENVELOPE RETROFITS. Thermal Envelopes VI/Technology Transfer and the Information Superhighway-Practices (pp. 575-582). Washington. D.C.: U.S. Department of Energy.

Dall'O', G. (2012). A methodology for evaluating the potential energy savings of retrofitting residential building stocks. Sustainable Cities and Society, 4, 12-21.

Diakaki, C., Grigoroudis, E., \& Kolokotsa, D. (2008). Towards a multi-objective optimization approach for improving energy efficiency in buildings,. Energy and Buildings(40), 17471754.

Energy Efficient and Integrated Urban Development Action. (2011). Holistic Strategies for Energy Efficient Refurbishment of the Housing Stock and Renewal of the Related Energy Supply System. Berlin: Baltic Union of Coprative Housing Associations.

ERA Group. (2011). Tower Renewal Implementation Booklet, An Apartment Community Initiative. Toronto: City of Toronto. 
Finch, G., Straube, J., \& Genge, C. (2009). AIR LEAKAGE WITHIN MULTI-UNIT RESIDENTIAL BUILDINGS: TESTING AND IMPLICATIONS FOR BUILDING PERFORMANCE. 12th Canadian Conference on Building Science and Technology, (pp. 529-544). Montreal, Quebec.

Genge, G., \& Rousseau, J. (1996). High-Rise Apartment Repair Needs Assessment. Ottawa: Canada Mortgage and Housing Corporation, Technical Policy and Research Division,.

Groleau, D., Allard, F., Gurracino, G., \& Peuportier, B. (2007). Technical Improvement of Housing Envelopes in France. Improving the Quality of Existing Urban Building Envelopes - Facades and Roofs. IOS Press.

Güçyeter, B. \&. (2012). Optimization of an envelope retrofit strategy for an existing office building. Energy \& Buildings, 55, 647-659.

Hanam, B., Finch, G., \& Hepting, C. (N/A). Meter Calibrated Energy Simulation of High Rise Residential. RDH Building Engineering Ltd.

Hopper, J., Littlewood, J., Taylor, T., Counsell, A., Thomas, M., \& Karani, G. (2012). Assessing retrofitted external wall insulation using infrared thermography. Structural Survey, 30, 245-266.

Huang, Y. (2012). Energy Benchmarking and Energy Saving Assessment In High-Rise MultiUnit Residential Buildings. Toronto: Ryerson University.

Hutcheon, N. B. (1963). Requirements for Exterior Walls. (C. B. Digest, Ed.) Ottawa: Division of Building Research, National Research Council.

Jian, Y. W., \& Jiang, Y. (2006). Influence of WWR on annual energy consumption for heating and air conditioning in residential buildings Heating Ventilating and Air Conditioning. Indoor and Built Environment(36), 1-5.

Karagiozis, A., Hartwig, K., \& Andreas, H. (2001). WUFI-ORNL/IBP Hygrothermal Model. Proceedings 8th Conference on Building Science and Technology, (pp. 158-183). Toronto.

Kesik, T. (2008). Anatomy of Tower Retrofit. Toronto: University of Toronto.

Kesik, T., \& Saleff, I. (2005). Differential Durability, Building Life Cycle and Sustainability. 10th Canadian Building Science \& Technology Conference. Ottawa: University of Toronto.

Kesik, T., \& Saleff, I. (2009). Tower Renewal Guidelines For the Comprehensive Retrofit of Multi-Unit Residential Buildings in Cold Climates. Toronto: Daniels Faculty of Architecture, Landscape, and Design; University of Toronto.

Lee, W., Yik, F., \& Burnett, J. (2003). A method to assess the energy performance of existing commercial complexes, Indoor and Built Environment. 12(5), 311-327. 
Ma, Z., Cooper, P., Daly, D., \& Ledo, L. (2012). Existing building retrofits: Methodology and state-of-the-art. Energy \& Buildings(55), 889-902.

McClelland, M. S. (2007). Concrete Toronto: A Guide to Concrete Architecture from the Fifties to the Seventies. Toronto: Coach House Books.

NRCan. (2002). Survey of Household Energy Use (SHEU) Summary Report. Ottawa: Natural Resources Canada's Office of Energy Efficiency. Retrieved from http://oee.nrcan.gc.ca/Publications/statistics/sheu-summary/pdf/sheu-summary.pdf

One Journal. (2010, 8 27). Rintheimer field: research project for energy-efficient home design. Retrieved from One Journal: http://www.onejournal.de/item/wissenschaftforschung/16/balkonsystem-vakuumdaemmung-im-praxistest-pr37166.html

Robinson, T. (2013). Efficient Window Collaborative: Design Guidance for New Windows in a Cold Climat. Twin Cities: University of Minnesota, Center for Sustainable Building Research. Retrieved from http://www.efficientwindows.org/downloads/ColdDesignGuide.pdf

Stewart, G. (2008). The Sustainable City: Tower Renewal Project. Toronto: ERA Architect.

Straube, J. (2006). The Building Enclosure. Building Science Digest.

Touchie, M., Pressnail, K., \& Binkley, C. (2012). Energy Retrofit Opportunities for Multi-Unit Residential Buildings in the City of Toronto. Toronto: University of Toronto.

Tower Renewal Office. (2010). Tower Renewal. Retrieved from City of Toronto: http://www.toronto.ca/tower_renewal/

U.S. Department of Energy. (2010). . eQUEST Quick Energy Simulation Tool. version 3.64. U.S. Department of Energy. Retrieved from http://apps1.eere.energy.gov/buildings/tools_directory/ software.cfm/ID=575/pagename_submenu=energy_simulation/pagename_menu=whole _building_analysis/pagename=subjects

Yang, J. (2009). Evaluation on energy and thermal performance for residential envelopes in hot summer and cold winter zone of china. Applied Energy, 86(10), 1970-1985.

Zimmermann, M. (2012). Prefabricated Systems for Low Energy Renovations of Residential Buildings. ECBCS Anex50. Birmingham: International Energy Agancy. Retrieved from http://www.ecbcs.org/docs/ECBCS_Annex_50_PSR.pdf 